\title{
A REVIEW OF THE FLOUNDERS AND SOLES OF JAPAN.
}

\author{
By David Starr Jordan and Edwin Chapin Starks, \\ Of Stanford Lniversity, California.
}

In this paper is given a descriptive catalogue of the species of the families Pleuronectidæ and Soleidæ, flounders and soles, known to inhabit the waters of Japan and the shores of the Japan Sea. It is based primarily on the collection made by Professors Jordan and Snyder in the summer of 1900. Series of these specimens are in the United States National Museum, in the British Museum, and in the museum of Stanford University. The new illustrative figures are the work of Mrs. Chloe Leslie Starks and Mr. William S. Atkinson.

The flounders and soles together constitute the suborder Heterosomata. The relations of this group are uncertain, but it is evident that these fishes have no special affinity with the Gadidæ or with other forms with jugular ventral fins. Boulenger associates the flounders with the Zeidæ, and suggests the derivation of both groups from the extinct family Amphistiidæ. But there is no positive warrant for this ingenious guess.

\section{Suborder HETEROSOMATA.}

\section{FLATFISHES.}

Cranium posteriorly normal; anteriorly with twisted vertex, to allow two orbits on the same side of the head; basis cranii not quite simple; dorsal fin long, of jointed rays; superior pharyngeals 4, the third longest, much extended forward, the inferior separate; ventral fins thoracic rarely wanting; of more than five rays, all articulate; no fin-spines; shoulder-girdle normal, the hypercoracoid perforate. In the very young fishes the two sides of the body are alike and the eyes are one on each side, with normal cranium.

KEY TO FAMHLIES OF HETEROSOMATA.

a. Preopercular margin more or less distinct, not hidden by the skin and scales of the head; eyes large, well separated; mouth moderate or large; teeth present.

Pleuronectide, I

aa. Preopercular margin adnate, hidden by the skin and scales of the head; eyes small, close together; mouth very small, much twisted; teeth rudimentary or wanting.

SOLEIDE, II 


\section{Family I. PLEURONECTID A.}

FLOUNDERS: HIRAME OR KAREI in 'Tapanese.

Body strongly compressed, oval or elliptical in outline; head unsymmetrical, the cranium twisted, both eyes being on the same side of the body, which is horizontal in life, the eyed side being uppermost and colored, the blind side lowermost and usually plain. In the very young fish the bones of the head are symmetrical, one eye on each side, and the body is vertical in the water. In most species the cranium becomes twisted, bringing the upper eye over with it. Eyes large, well separated; mouth small or large, the dentition various, the teeth always present; premaxillaries protractile; no supplemental maxillary bone; pseudo-branchiæ present; gills 4, a slit behind the fourth; lower pharyngeals separate; no air-bladder; preopercle with its margin usually distinct; not wholly adnate or hidden by the skin of the head; vent not far behind head, the viscera confined to the anterior part of the body; scales various, rarely ahsent, usually small; lateral lines usually present, extending on the caudal fin, sometimes duplicated or wanting. Dorsal fin long, continuous, of soft rays only, beginning on the head; anal similar, shorter; caudal various, sometimes coalescent with dorsal and anal; pectorals inserted rather high, rarely wanting; ventrals thoracie under the pectorals, usually of several soft rays, one of them sometimes wanting. Fishes mostly carnivorous, inhabiting sandy bottoms in all seas, some species ascending rivers.

Most of the flounders are valued as food, the flesh being white and wholesome, but rather tasteless, and in some species somewhat coarse. These fishes are known in Japanese as Karei, usually with an adjective prefix, indicating the different species, as Kurokarei, black flounder; Mizugarei, water flounder; Ishigarei, rock flounder. The larger ones are called Hirame or halibut (hira, broad; me, eye).

Apparently the members of the Psettinæ or Turbot tribe are more primitive than the other subfamilies represented in Japan. The relative simplicity of structure in the Halibut tribe is of the nature of degeneration.

The earliest fossil flounders, from the European Cretaceous, are related to the genus Bothus, which contains the Brill, Bothus rhombus, an ally of the Japanese genus, Platophrys.

KEY TO SUBFAMILIES OF PLEURONECTIDE.

$A$. Ventral fins unsymmetrical, dissimilar in position and usually also in form, the ventral fin of the eyed side being extended along the ridge of the abdomen. Eyes and color on the left side. (Turbot tribe) ................ Psetrin $E$, I

$A A$. Ventral fins symmetrical, similar in position and in form of base, the ventral of the colored side notextended along the ridge of the abdomen.

a. Mouth nearly symmetrical, the dentition nearly equally developed on both 
sides, the gape usually, but not always wide. Eyes and color on the right side in most northern forms, on the left side in others. (Halibut tribe.)

HiPPOGLOSSINA, II

aa. Mouth unsymmetrical, the jaws on the eyed side with nearly straight outline, the bones on the blind side strongly curved; teeth chiefly on the blind side.

$b$. Eyes and color on the right side (with occasional exceptions). (Plaice



I. Subfamily PSETTIN AE.

TURBOT TRIBE.

Large-mouthed flounders, with the ventral fins unsymmetrical.Mouth symmetrical, the dentition nearly equally developed on both sides; gape usually wide (narrow in Platophrys, Etropus, etc.), the maxillary commonly more than $\frac{1}{3}$ length of head; lower pharyngeals narrow, each with one or more rows or a narrow band of small, sharp teeth; teeth in jaws acute; eyes not minute; pectorals and ventrals usually well developed; edge of preopercle free; ventral fins dissimilar in form or in position, that of the left or eyed side inserted on the ridge of the abdomen, its base extended along this ridge, its rays more or less wide apart; caudal fin rounded or subtruncate; no accessory lateral line; anal spine usually weak or obsolete; a pelvic spine sometimes developed; vertebræ in moderate or small number, 31 to 45 . Body sinistral. Species chiefly tropical or subtropical in distribution, scantily represented in Japan.

The Turbots are here placed at the beginning of the flounder series as the most primitive of flounders, though not the most simple in anatomical structure.

KEY TO GENERA.

a. Pectoral fin of both siles present; septum of gill-cavity below gill-arches without foramen; a deep emargination near the isthmus; ventral fins free from anal.

$b$. Vomer toothless; ventral fins free from anal; caudal fin subsessile.

c. Lateral line with a distinct arch in front; teeth small, uniserial, or biserial.

d. Interorbital space more or less broad, deeply concave, at least in the males; form broad ovate; gillrakers short and thick.

e. Scales small, ctenoid, adherent, 75 to 100 or more; teeth mostly uniserial; anterior rays of dorsal not elevated; pectoral of left side usually filamentous in the male; vertebræ (in P. lunatus) $9+30=39$. Platophrys, 1

$e e$. Scales large, deciduous; anterior dorsal rays not elevated.......Scæops, 2

$d d$. Interorbital space narrow, sometimes reduced to a simple ridge; dorsal not elevated in front; scales large, firm; gillrakers slender; teeth in two series....................................... Engyprosopon, 3

II. Subfamily HIPPOGLOSSIN AE.

HALIBUT TRIBE.

Large-mouthed flounders, with the ventral fins symmetrical.-Mouth symmetrical, the jaws and the dentition nearly equally developed on both sides; gape usually wide, the maxillary more than $\frac{1}{3}$ length of head; lower pharyngeals narrow, usually with but 1 or 2 rows of sharp 
teeth; teeth in jaws usually acute; eyes large; edge of preopercle free; pectoral and ventral fins well developed, the ventral fins similar in position and in form of base, the ventral fin of the eyed side not being attached along the ridge of the abdomen. Septum of gill cavity without foramen.

The existing species are mostly arctic or subarctic, and mostly dextral, but the more primitive forms (allied to Paralichthys) are largely semitropical and sinistral.

\section{KEY TO GENERA.}

a. Vertebræ and fin rays in moderate numbers (vertebræ fewer than 46 , dorsal rays fewer than 95, anal rays fewer than 75 ); caudal fin not concave, the middle rays longest.

b. Dorsal fin beginning in advance of eye; teeth sharp, uniserial; eyes sinistral (rarely reversed); lateral line with a strong arch in front; no anal spine. Species tropical or semitropical, aliied to Puralichthys.

c. Scales moderately ctenoid; gillrakers slender; some of the teeth canine-like; none of the rays much produced; vertebræ 30 to 40 .

d. Lateral line with a short accessory branch extending from near the opereular angle to base of dorsal fin; body rather deep........ Pseudorhombus, 4 $d d$. Lateral line without accessory branch; body more elongate; mouth large.

$b b$. Dorsal fin beginning above the pupil.

Paralichthys, 5

e. Lateral line with short more or less semicircular arch in front; vertebræ 35 to 41; anal spine present or absent; body normally sinistral; scales ctenoid; teeth rather small (genera allied to Verasper, in the temperate Pacific).

$f$. Anal spine weak or obsolete; teeth in two series.

g. Gillrakers long and slender ......................... Xystrias, 6

gg. Gillrakers short and broad ........................ Verasper, 7

ff. Anal spine strong; teeth uniserial; interorbital area scaly...Acanthopsetta, 8

$e e$. Lateral line without distinct arch in front; vertebræ 40 to 46 ; body normally dextral; scales ctenoid; anal spine usually present. Species of subarctic distribution, allied to Hippoglossoides.

h. Lateral line simple, without accessory branch; teeth sharp, uniserial below. $i$. Upper eye lateral; no bony or warty plates.

$j$. Jaws with distinct canines; lateral line descending in a long curve.

jj. Jaws with subequal teeth; lateral line nearly straight.

Cynopsetta, 9

$x$. Scales small, chiefly ctenoid; flesh firm; gillrakers rather few, 10 to 15 below angle; teeth uniserial in both jaws; vertebræ 45 .

Hippoglossoides, 10

$x x$. Scales mostly cycloid; flesh feeble; gillrakers rather numerous, about 25 below angle. ........................ Cleisthenes, 11

ii. Upper eye nearly vertical, on the middle line of upper outline of body, as in Atheresthes, the dorsal beginning behind it; head with warty plates....................................... Protopsetta, 12

aa. Vertebræ and fin rays much increased in number (the vertebræ about 50; dorsal rays about 100 , anal rays about 85 ); body comparatively elongate; caudal fin lunate; lateral line simple; and spine mostly obsolete. Dextral species, arctic in distribution. (Genera allied to Hippoglossus.)

$y$. Large teeth not arrow-shaped, biserial above, uniserial below; scales very small, cycloid; gillrakers long and slender; eyes strictly lateral. 
$z$. Lateral line with an anterior arch; lower pharyngeal teeth biserial; vertebræ

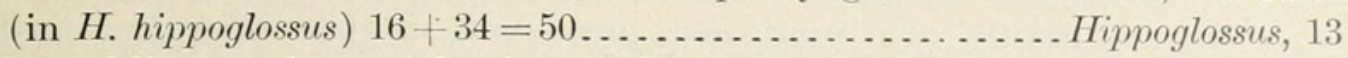

$z z$. Lateral line nearly straight; lower pharyngeal teeth in one row.

Reinhardtius, 14

$y y$. Large teeth in both jaws arrow-shaped, biserial, some of them depressible; upper eye with vertical range; gillrakers short; scales deciduous, ciliated; lateral line without arch; flesh soft. Vertebræ $12+37=49$. Atheresthes, 15

\section{Subfamily PIFURONHCTIN AE.}

\section{PLAICE TRIBE.}

Mouth small, unsymmetrical, the jaws on the eyed side with nearly straight outline, the bones on the blind side strongly curved; dentition chiefly developed on the blind side; eyes large; edge of preopercle not hidden by the scales; pectoral fins well developed; vertical fins well separated; ventral fins nearly or quite symmetrical, that of the eyed side not prolonged along the ridge of the abdomen; anal spine usually strong (obsolete in Microstomus and Veræqua). Body dextral (except frequently in Platichthys stellatus). Species arctic or subarctic in distribution.

KEY TO GENERA.

a. Vertebræ in moderate number (36 to 44 ); dorsal rays 65 to 80 ; anal rays 45 to 60 .

b. Teeth in bands, small, acute; lower pharyngeals narrow, with small teeth, usually two-rowed.

c. Lateral line without branch, and with a broad arch in front; scales large, ctenoid, caducous; gillrakers short and sharp . . . . . . . . . . . Alxops, 16

cc. Lateral line with an accessory dorsal branch, without arch in front; lips thick, folded; dorsal fin beginning on blind side ........Pleuronichthys, 17

bb. Teeth in a single row, usually bluntish or incisor-like.

d. Lateral line with an accessory dorsal branch, and with a distinct arch in

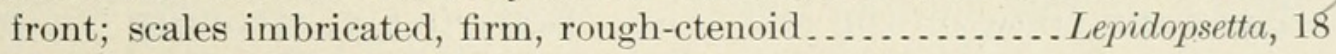

dd. Lateral line without accessory branch.

e. Lateral line with a semicircular arch in front.

$f$. Body robust; anal spine present; scales usually but not always

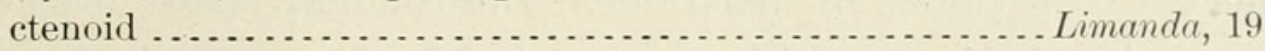

$f f$. Body slender and fragile; scales very small, cycloid; no anal

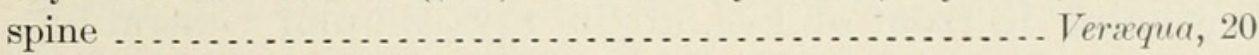

ee. Lateral line without arch in front.

$h$. Scales present.

$i$. Bases of vertical fins without stellate tubercles.

$j$. Scales regularly imbricate, all on eyed side, ctenoid in both sexes.

$k$. Scales large (60 to 65 ), loose, with slender spinules; interorbital space narrow, naked; teeth not close-set.

l. Eyeball scaly above.......................... . Dexistes, 21

ll. Eyeball scaleless............................................. 22

$\ddot{j}$. Scales imperfectly imbricated or else not ctenoid; teeth blunt, closeset.

$m$. Scales chiefly cycloid in both sexes; lower pharyngeals each with one row of small teeth . . . . . . . . . . . . . . . Pleuronectes, 23

$\mathrm{mm}$. Scales rough-ctenoid in the male, mostly cycloid in the female; lower pharyngeals large, with 5 or 6 rows of large blunt, close-

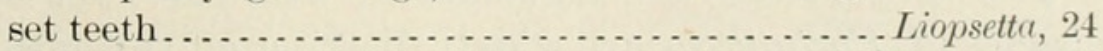


ii. Bases of fin rays with rough tubercles; scales rough, stellate, scattered, mostly not imbricated; head with stellate tubercles; lateral line scaleless; lower pharyngeals broad, each with three rows of blunt teeth; teeth in jaws incisor-like................. Platichthys, 25

$h h$. Scales none; body naked or with rough warts or tubercles.

$n$. Body naked in youth, the adult with irregular rows of horny elevations, two or three on the eyed side; blind side naked......... Kareius, 26

$n n$. Body naked in youth, the adult with many rows of warty tubercles, some of them regularly arranged, these on the eyed side; blind side



aa. Vertebræ in increased number (48 to 65 ); dorsal rays 90 to 120 ; anal rays 70 to 100 ; teeth broad, incisor-like; lateral line simple, straight; scales small all cycloid; body elongate.

$m$. Anal spine obsolete; skull with few mucous cavities.......... Microstomus, 28 $\mathrm{mm}$. Anal spine present; skull with large mucous cavities...... Glyptocephalus, 29

\section{PLATOPHRYS Swainson.}

Solea Rafinesque, Indice di Ittiologia Siciliana, 1810, p. 52 (rhomboide); not of Quensel, 1806.

Platophrys Swarnson, Nat. Hist. Class'n Fishes, II, 1839, p. 302 (oeellatus).

Peloria Cocco, Intorno ad Alcuni Pesci del mar di Messina, Giorn. del Gabin., 1844, pp. 21-30, Lettere di Messina (heckeli, a larval form of $P$. podas); not Pelorus of Montfort, 1808.

? Coccolus Bonaparte, in Cocco, Alcuni Pesci Messina, 1844, p. 21 (annectens; larval form-probably of $P$. podas, with the right eye in transit to the left side).

Bothus Bonaparte, Catologo Metodico, 1846, p. 49 (podas); not of Rafinesque. Rhomboidichthys Bleeker, Act. Soc. Sci. Indo-Nederl. Manad. and Makassar, $1857-58$, p. 67 (myriaster).

Platophrys Bleek er, Comptes Rendus Acad. Sci. Amsterd., XIII, 1862, Pleuron., 5 (ocellatus).

Eyes and color on the left side. Body ovate, strongly compressed; mouth of the large type, but comparatively small; the maxillary $\frac{1}{3}$ or less of the length of the head; teeth small, subequal, in 1 or 2 series; no teeth on vomer or palatines. Interorbital space broad and concave, broadest in adult males. Gillrakers moderate. Dorsal fin beginning in front of eye, all its rays simple; ventral of colored side on ridge of abdomen; caudal convex behind; pectoral of left side usually with one or more filamentous rays, longest in the male. Scales very small, ctenoid, adherent; lateral line with a strong arch in front. Coloration usually variegated.

This well-marked genus is widely diffused in the warm seas. The sexual differences are greater than usual among flounders, and the different sexes have often been taken for different species. As a rule, in the males, the pectoral fin on the left side is much prolonged, the interorbital area is much widened and very concave, and there are some tubercles about the snout and lower eye. The young fishes, as is usually the case, resemble the adult females.

The very young are translucent, with the eyes symmetrical. The species of Platophrys are widely distributed through the warm seas, no 
tropical waters being wholly without them. All the species of Platophrys are extremely closely related, and can be distinguished with difficulty. On the other hand, the variations due to differences of age and sex are greater than in any other of our genera.

( $\pi \lambda \alpha \tau v_{s}^{\prime}$, broad; ó $\phi \rho v_{s}$, eyebrow.)

\section{PLATOPHRYS MYRIASTER (Temminck and Schlegel).}

Rhombus myriaster Temminck and Schlegel, Fauna Japonica, Poiss., 1846, p. 181, pl. xCII, fig. 2 (Nagasaki).

Rhomboidichthys myriaster Bleek ER, Act. Soc. Ind. Nederl., I. Manado and Macassar, p. 67 (Celebes); Atlas, Pleuron., pl. rx, fig. 4 (Celebes).—Günther, Cat., IV, 1864, p. 436 (Celebes; China).-Ishikawa and Matsu'üra, Prel. Cat., 1897, p. 25 (Kagoshima).

Platophrys myriaster Jordan and SNyder, Check-List Fish, Japan, 1901, p. 122.Jordan and Evermann, Proc. U. S. Nat. Mus., XXV, p. 365 (Keerun, Formosa).

Habitat.- Southern Japan, southward to China, Formosa, and the East Indies; north to the island of Kiusiu.

Head, $4 \frac{1}{6}$ in length to base of caudal; depth, $1 \frac{3}{4}$; upper eye, $3 \frac{1}{5}$ in head; maxillary, $3 \frac{3}{4}$; snout, $4 \frac{1}{4}$; interorbital space, 3 ; dorsal, 94; anal, 71; scales, 104 .

Body rather broad; the anterior upper outline a short, even curve, becoming nearly vertical in front of eyes; snout somewhat projecting, its upper outline not continuous with that of head; mouth arched; each jaw with a row of sharp, slender, recurved teeth, outside of which toward front is another row of more irregular stouter but shorter teeth; maxillary reaching very slightly past anterior rim of lower orbit; interorbital broad and concave, rising on each side to a high, smooth orbital rim; middle of upper eye over posterior edge of lower eye; a slight projection near tip of snout on blind side; gillrakers very short and blunt, 6 developed on lower limb of arch, only very small tubercles above.

Origin of dorsal just above snout, a little below the level of superorbital rim of lower eye; longest dorsal rays equal to those of anal; their length, $2 \frac{1}{2}$ in head; pectoral long and very slender; its length, $1 \frac{1}{10}$ in head; caudal double truncate; arch of lateral line small, its length twice as great as its height, and contained 6 times in straight part of lateral line or two times in head. Scales very small and everywhere cycloid except a definite area at base of dorsal and anal fins, which is roughly ctenoid; at about middle of fins this area is 3 or 4 scales deep, but it tapers at each end and disappears. Scales on opercles, cheeks, posterior half of interorbital space and top of head to front of upper eye; front of head, snout, and mandible naked.

Color, rather light brown, everywhere on head and body with small brown spots ringed with light brown, lighter than ground-color, and light-blue spots ringed with dark brown; an irregular, blended, dark- 
brown blotch just behind arch of lateral line and another at middle of straight portion of lateral line; dorsal and anal inconspicuously and irregularly dotted with brown dots, and at regular intervals, about 10 rays apart is a round spot, dark, nearly as large as pupil, at base of rays; 1 or 2 very faint bars on pectoral; caudal dark at base and tip of rays, a broad light band across its middle.

The above description is drawn from a female example $16 \mathrm{~cm}$. in length from Keerun, Formosa. We did not find the species in Japan, although originally described from Nagasaki.

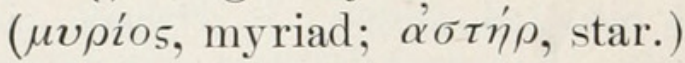

\section{SCAOPS Jordan and Starks.}

Scrops Jordan and Starks, Bull. U. S. Fish. Comm., XXII, 1902 (1904), p. 627 (grandisquama).

This genus in near Platophrys, differing in the large, caducous scales; the fin rays are not produced in the male and the sexual differences are less pronounced than in Platophrys. Teeth one-rowed; gillrakers very short. Size small. A second species, Scæops precilura (Bleeker), very similar to the type of the genus, occurs in the East Indies. Scrops renandria is found in Hawaii.

(бкацо́s, left; c̋», eye.)

KEY TO SPECIES.

a. Scales large, 36 in a lateral series. Color plain brownish; caudal fin with a black spot above and one below .......................... grandisquama, 2

aa. Scales smaller, 45 in a lateral series; upper eye more posterior. Color light brown, freckled with darker brown; caudal fin with three dark cross-shades. kobensis, 3

\section{SCÆOPS GRANDISQUAMA (Schlegel).}

DARUMAGAREI (DARUMA $a$-FLOUNDER); MARUTAGAREI (LOG-FLOUNDER).

Rhombus grandisquama Schlegel, Fauna Japonica, Poiss., p. 183, 1846, pl. xcII, figs. 3,4 (Nagasaki).

Rhomboidichthys grandisquama Günther, Cat., IV, p. 437 (China, also by error ascribed to the Gulf of Fonseca).--Isнiк Awa, Prel. Cat., 1897, p. 25 (Kishin).Namiye, Class. Cat., 1881, p. 110 (Kishin).

Engyprosopon grandisquama Jordan and Snyder, Fish Japan, Annot. Zool. Jap. Check-List, 190, p. 122 (Nagasaki).

Scrops grandisquama Jordan and Starks, Bull. U. S. Fish Comn., XXII, 1904, p. 627 , pl. vin, fig. 2 (Owari Bay, Sagami Bay).

Habitat. - Sandy coasts of Japan, northward to Misaki.

Head, $4 \frac{1}{6}$ in length to base of caudal; depth, $1 \frac{4}{5}$; upper eye, $3 \frac{1}{4}$ in head; maxillary, $3 \frac{1}{4}$; snout, $4 \frac{3}{4}$; dorsal, 79 ; anal, 60 ; series of scales, 36 .

Body rather broad; the anterior upper profile steep; snout a little projecting with a shallow notch above; maxillary reaching past front

a Daruma, a squat image of Buddha, a name also applied to certain Scorpænoid and cottoid fishes. Karei, garei for euphony, flounder. 
No. 1484. JAPANESE FLOUNDERS AND SOLES-JORDAN\& STARKS. 169

of lower eye, nearly to anterior margin of pupil; interorbital space of male, $2 \frac{1}{2}$ in head; of female, 4 in head (much narrower in small individuals). Male with a sharp spine on colored side of snout near tip, projecting outward and forward; another on anterior upper margin

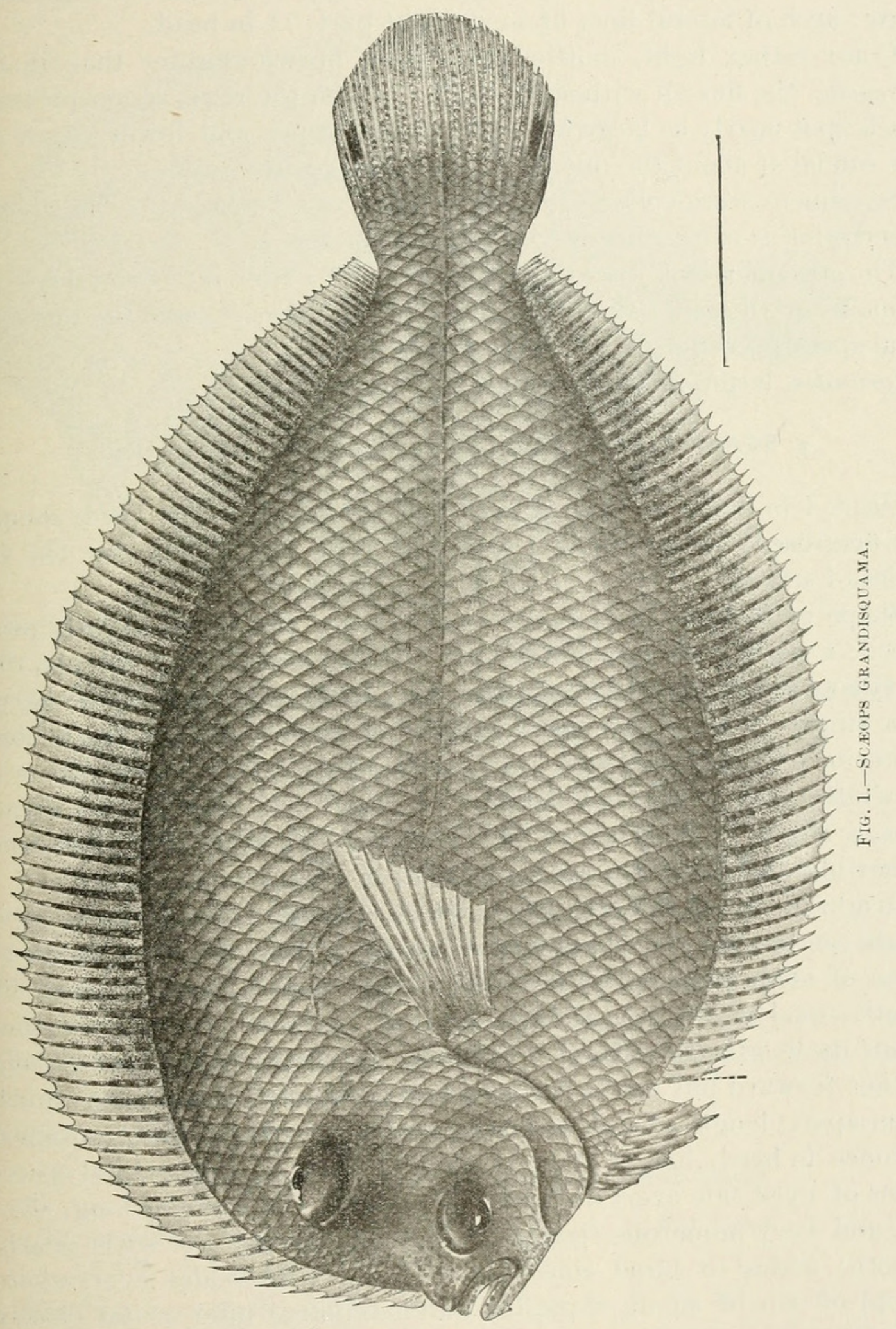

of lower eye, and a few rough serrations behind it; lower margin of upper eye serrated, the serræ coarser anteriorly, these serrations and spines all absent in the female. A very slight projection on snout, 
but no spine as in the male; the orbital rims raised but smooth. Six short gillrakers developed on lower limb of arch, none on upper.

Origin of dorsal on blind side opposite upper rim of lower eye; pectoral of colored side long, narrow, and pointed, its length equal to that of head; pectoral of blind side blunt and only half as long as its mate; arch of lateral line, $3 \frac{4}{5}$ in straight part, $1 \frac{1}{2}$ in head.

Color rather light, mottled with dark brown, lighter than in $S$. kobensis; the fins all with small dark spots on the rays; a conspicuous black spot nearly as large as pupil on the upper and lower edges of the caudal at about the middle of the length of the rays.

Specimens were collected at Wakanoura and Nagasaki. The above description is of specimens 11 or 12 centimeters long.

The specimen here drawn is of a male with a wide interorbital space. Females of the same size as our type of $S$. kobensis have the interorbital space no wider than in that species.

(grandis, large; squama, scale.)

\section{SC EOPS KOBENSIS Jordan and Starks, new species.}

Head, 4 in length to base of caudal; depth, $1 \frac{5}{6}$; eye, 4 in head; snout, $4 \frac{3}{4}$; maxillary, $3 \frac{1}{2}$; dorsal, 80 ; anal, 63 ; pores, in lateral line $56 ; 45$ series of scales.

Shape of body as in Scxops grandisquama; the snout slightly produced; a slightly sharper notch above its tip; mouth very oblique, the maxillary reaching to front of lower eye; teeth small and rather sharp, in a single even row on jaws; middle of upper eye a little behind posterior edge of lower eye; interorbital space rather deeply concave, its width equal to vertical diameter of upper eye; no tubercles about eyes, a slight prominence at tip of snout; gillrakers very short and rather blunt, 7 developed on lower limb of arch, none on upper.

Origin of dorsal at notch above snout opposite front of lower eye; height of longest dorsal rays near middle of fin, 2 in head, equal to those of anal; pectoral of eyed side long, narrow, and pointed; its length equal to that of head; pectoral of blind side short and rather blunt, its length $2 \frac{1}{2}$ in head; ventral of eyed side 6-rayed, extending: farther forward but not so far back as that of blind side, its rays much wider apart; length of arch of lateral line $3 \frac{1}{2}$ in straight part, contained $1 \frac{3}{4}$ times in head; height of arch equal to width of interorbital space; scales of eyed side everywhere finely ctenoid; the spinules long, slender, and very numerous, easily broken off, leaving the scale nearly smooth; scales of blind side cycloid; head with scales everywhere except on tip of snout, mandible and maxillary; interorbital closely scaled.

Color light grayish brown, everywhere mottled with irregular spots of very dark brown; the colors not much shaded into each other and in sharp contrast; dorsal, anal, and ventral with fine spots of dark 
brown on the rays; not involving the membrane; caudal with three indistinct dark cross-bands; pectoral with fine, inconspicuous, dusky spots; a dark spot on base of rays.

This species may be known from Scrops grandisquama by the smaller scales and more posterior upper eye.

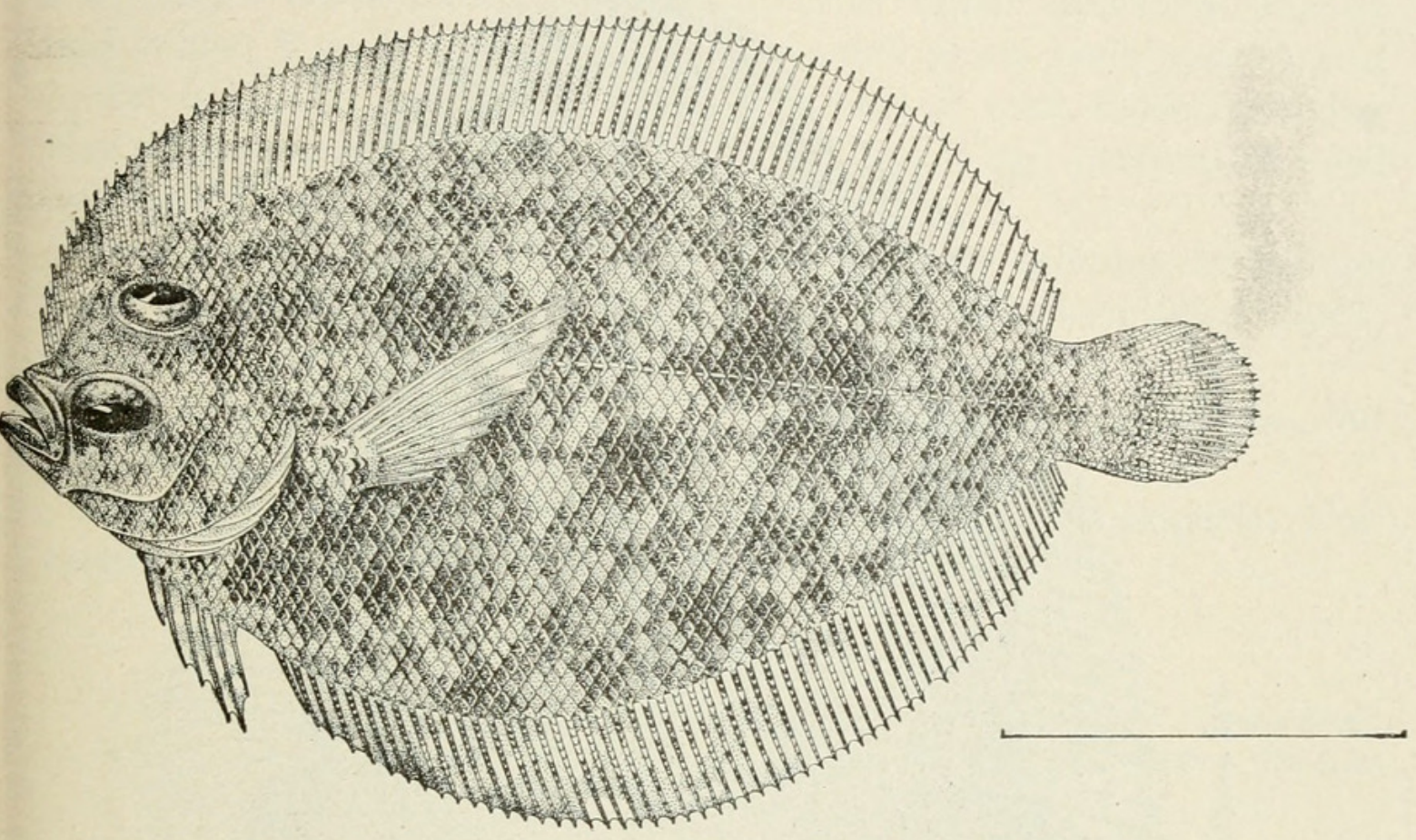

FIG. 2.-SCAOPS KOBENSIS.

Type.-The only specimen was collected at Kobe. It is $83 \mathrm{~mm}$. in length and is numbered 9822, Stanford University.

\section{ENGYPROSOPON Günther.}

Engyprosopon Günther, Cat. Fish, IV, 1864, p. 431 (mogkii).

Body elliptical, covered with rather large, firm scales; teeth tworowed; gillrakers long and slender; interorbital space narrow; fin rays not produced in either sex. Sexes similar. Small sand-colored flounders of the Pacific, allied to Amoglossus, but less fragile in habit, and with the teeth biserial, not sharp and uniserial as in Arnoglossus. The interorbital space, though narrow, is broader than in Amoglossus, and in some species somewhat concave.

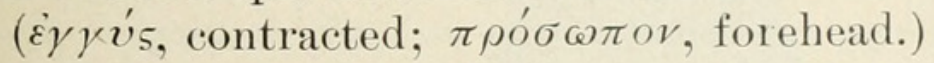

4. ENGYPROSOPON IIJIM Æ Jordan and Starks.

Engyprosopon iijimx Jordan and Starks, Bull. U. S. Fish Comn., XXII, 1904, p. 626, pl. vin, fig. 1 (Suruga Bay, Japan).

Head, 4 in length; depth, 2.33 to 2.5 ; D. 80 to 89 ; A. 69 to 72 ; scales, 50 to 53 ; eye, 3 in head; maxillary, 3.5 ; pectoral of eyed side, 1.2; of blind side, 3 ; ventral, 2.25; caudal, equal to head. Anterior profile evenly curved, the orbits not reaching to its edge; eyes separated by a narrow sharp ridge, the lower the more anterior; mouth 
small, the maxillary very much curved and reaching to a little past front of orbit; teeth small and set in a single row; six very short gillrakers on lower arch of first gill. Scales finely ctenoid, the spinules on the scales slender and very numerous; blind side with "cycloid

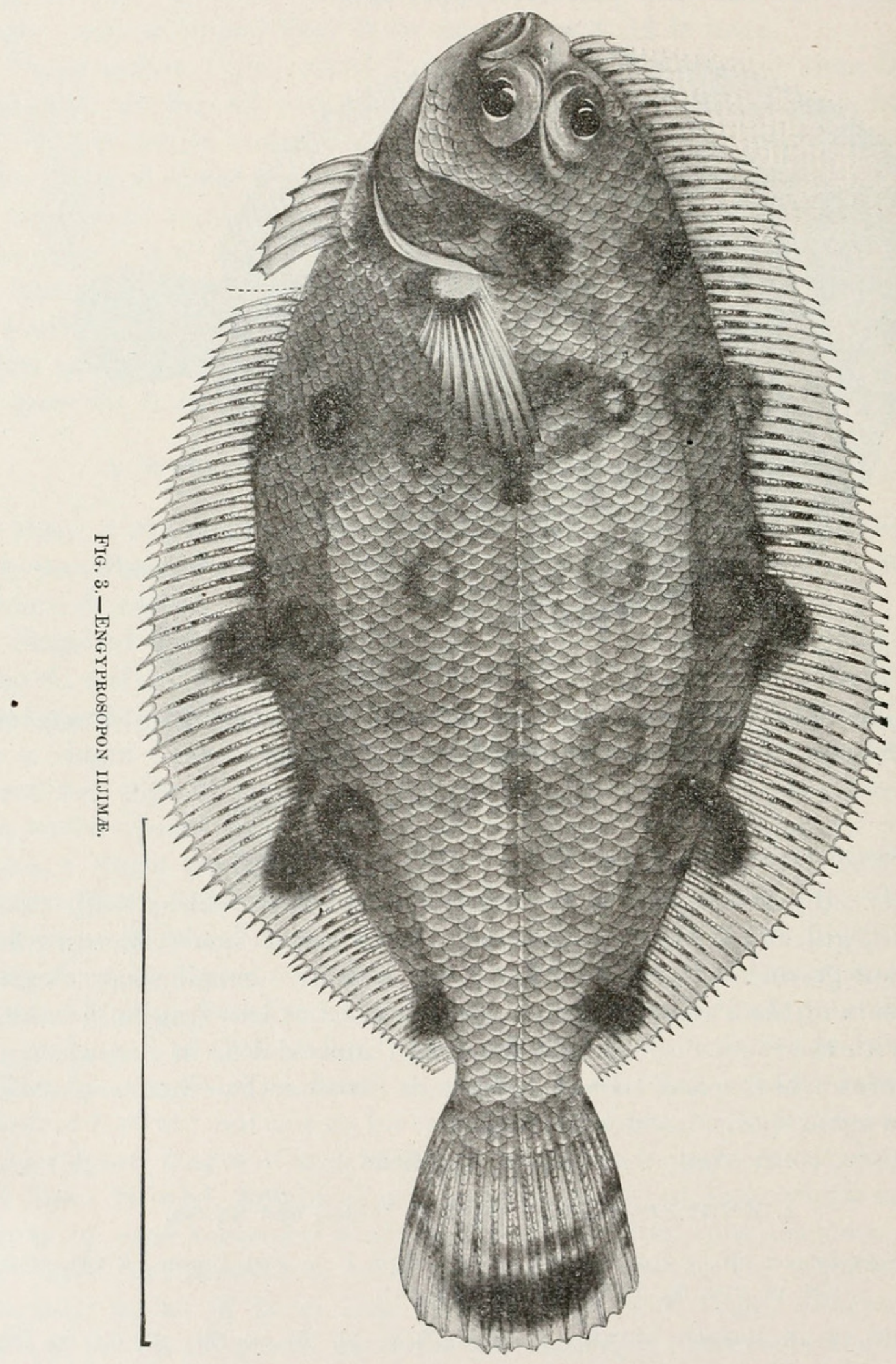

scales; lateral line with a very abrupt, short, high curve, its height contained 1.83 in its chord, which is half length of head, its beginning opposite the terminal third of pectoral. Dorsal beginning in advance of eye; pectoral of eyed side long and slender, of blind side less than 
half as long; ventral with 6 rays, that of blind side not prolonged, its base beginning behind front of ventral of eyed side and its tip reaching farther past front of anal; caudal rounded behind, its outer edges broadly rounded, scarcely angulated.

Color light brown, spotted with dark brown, ocellated spots, 3 a ove and 3 below lateral line, the anterior upper spot in advance of that below; 5 spots with edges more blended along body near base of dorsal, 4 similar ones along body near base of anal, these involving base of fins; one on opercle just above gill-opening; pectoral of eyed side dark brown.

Two small specimens taken in from 45 to 60 fathoms, in Suruga Bay; the former, the type, $65 \mathrm{~mm}$. in length, is numbered 51461 , U.S.N.M.; the other is No. 8387, Stanford University.

The species differs somewhat from the type of Engyprosopon, but it is doubtless referable to the same genus.

(Named for Dr. Iijima, professor of zoology in the Imperial University of Tokyo.)

\section{PSEUDORHOMBUS Bleeker.}

Pseudorhombus Bleek er, Comptes Rendus, Amsterd., XIII, 1862, p. 5 (polyspilos). Rhombiscus Jordan and Snyder, Proc. U. S. Nat. Mus., XXIII, 1900, p. 379 (cinnamomeus).

This genus is closely related to Paralichthys, which it replaces in the East Indian region. It differs in the presence of a short accessory branch of the lateral line, extending upward and forward from near the angle of the opercle to the dorsal fin. The body is less elongate than in Paralichthys, the mouth smaller, with feebler teeth, and the species are smaller in size. All belong to the fauna of southeastern Asia.

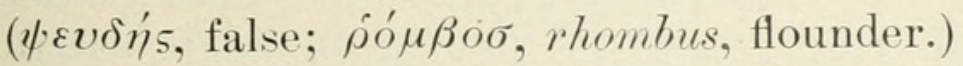

KEY TO SPECIES.

a. Scales small, 65 to 89 in lateral line series.

b. Scales ctenoid on blind side, as well as on eyed side; D. 80; A. 60. Scales 80; Gillrakers 8 below angle of arch; color dark; a black blotch on lateral line .cinnamomeus, 5

$b b$. Scales cycloid on blind side.

c. Gillrakers rather few, 8 to 11 below angle of arch.

d. Scales moderate, 74 to 80 in lateral line.

e. Pores in lateral line 79 ; D. 80 ; A. 63 ; depth $1 \frac{7}{8}$ in length; canines rela-

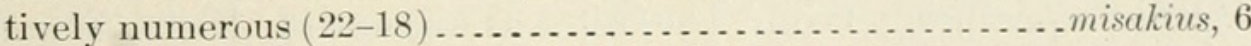

ee. Pores 74 ; D. 78 ; A. 62 ; depth $2 \frac{1}{10}$; canines few (about 20-12) .oligodon, 7 $d d$. Scales very small, 98 in lateral line; D. $74 ;$ A. 56 ; depth $2 \frac{2}{7}$ in length.

dupliciocellatus, 8

cc. Gillrakers numerous, 16 or 18 below angle of arch; D. 77 ; A. 52 ; scales 60 ;

body with about 5 dark ocelli .......................... ocellifer, 9 aa. Scales large, 40 to 50 in lateral series; D. 66 ; A. 48 ; mouth small; body with pale spots besides dark ones ............................ oligolepis, 10 


\section{PSEUDORHOMBUS CINNAMOMEUS (Schlegel).}

GANZOBIRAME (GANZ0, $a$ HALIBUT).

Rhombus cinnamomeus Schlegel, Fauna Japonica, Poiss., 1846, p. 180, pl. xcirI (Nagasaki).-Bleek ER, Act. Soc. Ind. Nederl., III, Japan p. 25 (Nagasaki). Pseudorhombus cinnamomeus GüNTher, Cat., IV, 1862, p. 427 (Nagasaki).-NAMiye, Class. Cat., 1881, p. 110 (Tokyo).-Otaki, Journ. Imp. Bureau Fish, Tokyo, 1897, p. 6, pl. in, fig. 2 (S. E. Japan).--Isнrkawa, Prel. Cat., 1897, p. 25 (Kishin, Tosa).

Rhombiscus cinnamomeus Jordan and Snyder, Proc. U. S. Nat. Mus., 1900, p. 379 (Tokyo); Check-List, p. 121 (Yokohama, Nagasaki).-Jordan and Seale, Proc. Davenport Ac. Sci., X, 1905, p. 16, (Hong Kong).

Habitat. - Coasts of Southern Japan and China, north to Tokyo.

Head, $3 \frac{3}{4}$ in length to base of caudal; depth, $1 \frac{9}{10}$; eye, $5 \frac{3}{4}$ in head;

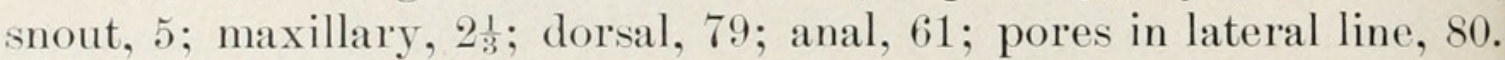

Eyes nearly vertícal or the lower very slightly more posterior; separated by a narrow, rather high, sharp, naked ridge; maxillary reaching to below posterior edge of lower eye; gape of mouth very much arched; teeth rather sharp and irregular in position and size; front of mandible truncate and subvertical; lower margin concave, and posterior end forming a conspicuous angle on lower side of head; gillrakers, short and pointed, teethed on the inner margin, the longest $\frac{2}{3}$ of diameter of pupil, 8 or 9 developed on lower limb of arch.

Dorsal beginning on blind side opposite front of upper eye; pectoral rather slender, its base nearly horizontal, reaching a little past angle of lateral line; length of pectoral of eyed side $1 \frac{3}{4}$ in head; that of blind side $2 \frac{1}{4}$ : ventrals rather small, that of eyed side a little nearer abdominal ridge than the other and a very little more anterior; length of ventral of eyed side contained 4 times in head; caudal double truncate, the middle rays reaching a sharp point, their length contained $1_{5}^{2}$ in head; height of curve of lateral line $3 \frac{4}{5}$ in head; length of curve $1 \frac{1}{3}$; scales everywhere ctenoid except anteriorly on blind side; posterior part of mandible and maxillary with a few rough scales, otherwise naked; snout and interorbital ridge naked.

Color of body uniform brownish with a spot at angle of lateral line, sometimes large and diffused, sometimes small and distinct; fins light and indefinitely speckled with light brown; slight traces of crossstreaks on ventral, none on pectoral.

Here describe from a specimen $23 \mathrm{~cm}$. in length from Tokyo. Other specimens from Tsuruga, Wakanoura, Kobe, Onomichi, Nagasaki, Hukata, Kawatana, and Tokyo. We have also a young example from Hongkong.

This species is one of the commonest of Japanese flounders, standing in that regard next to Paralichthys olivaceus. 
It may be known from $P$. misakius and $P$. ocellifer by the ctenoid scales of the blind side; from the latter by its few gillrakers, and from the former by its more angulated head and higher and sharper interorbital ridge. Other differences appear in the description of Pseudorhombus misakius.

(cinnamomeus, cinnamon-colored.)

6. PSEUDORHOMBUS MISAKIUS Jordan and Starks, new species.

\section{Habitat. - Coasts of Southern Japan.}

Head, $3 \frac{4}{5}$ in length to base of caudal; depth, $1 \frac{7}{8}$; eye, 5 in head;

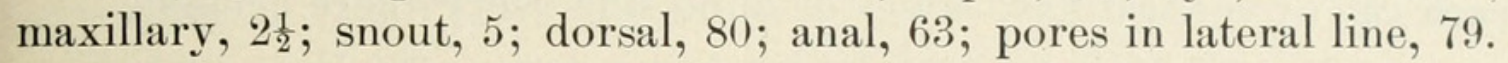

Anterior upper profile descending more abruptly than in $P$. cinnamomeus, the snout not so much produced, and the notch in front of upper eye smaller and sharper; mouth very much arched; maxillary reaching

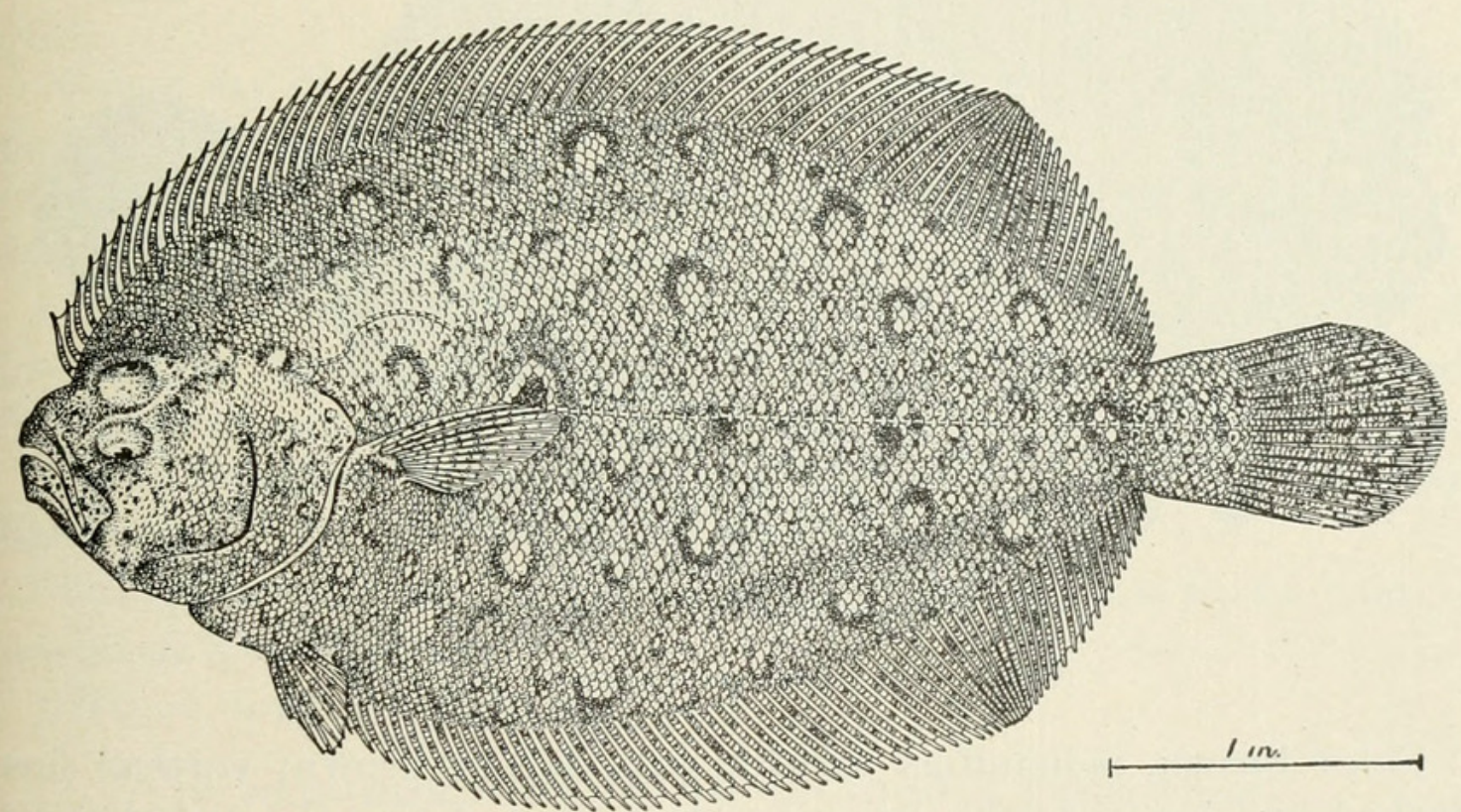

Fig. 4.-Pseudorhombus misakius. (Kobe.)

to below posterior margin of pupil; teeth smaller than in $P$. cinnamomeus, but otherwise similar; canines 17 or 18 in lower jaw, on each side, 20 to 24 on each premaxillary. Tip of mandible truncate, even with premaxillary when mouth is closed; lower edge of mandible nearly straight, slightly concave toward its tip, but not strongly concave, thus making a sharp angle below its blunt tip as in $P$. cinnamomeus; neither does its posterior end form an angle at lower outline of head; interorbital space low, not projecting above level of cheek; it is rather narrow but smoothly rounded (interorbital space a high sharp ridge in $P$. cinnamomeus); gillrakers very slightly longer than in $P$. cinnamomeus and not sharply pointed; the longest as long as diameter of pupil; 10 or 11 of them developed on lower limb of arch.

Origin of dorsal opposite notch in upper profile, or somewhat in front of anterior margin of upper eye; pectorals broadly rounded,

Proc. N. M. vol. xxxi-06-12 
that of eyed side reaching two-thirds of diameter of eye past arch of lateral line, its length contained 2 times in head, its base scarcely so nearly horizontal as that of $P$. cinnamomeus; pectoral of blind side $2 \frac{2}{5}$ in head; ventrals both longer and wider than in $P$. cinnamomeus, though having the same number of rays (6); length of ventral of eyed side $2 \frac{3}{5}$ in head, its origin slightly in front of that of blind side; caudal pointed, its posterior margin double truncate; height of curve of lateral line $4 \frac{1}{5}$ in head, its length 2 (shorter than in $P$. cinnamomeus); snout and lower jaw naked; a few scales on posterior edge of maxillary; scales on eyed side everywhere strongly ctenoid, including a row on each ray of vertical fins; scales of blind side everywhere cycloid.

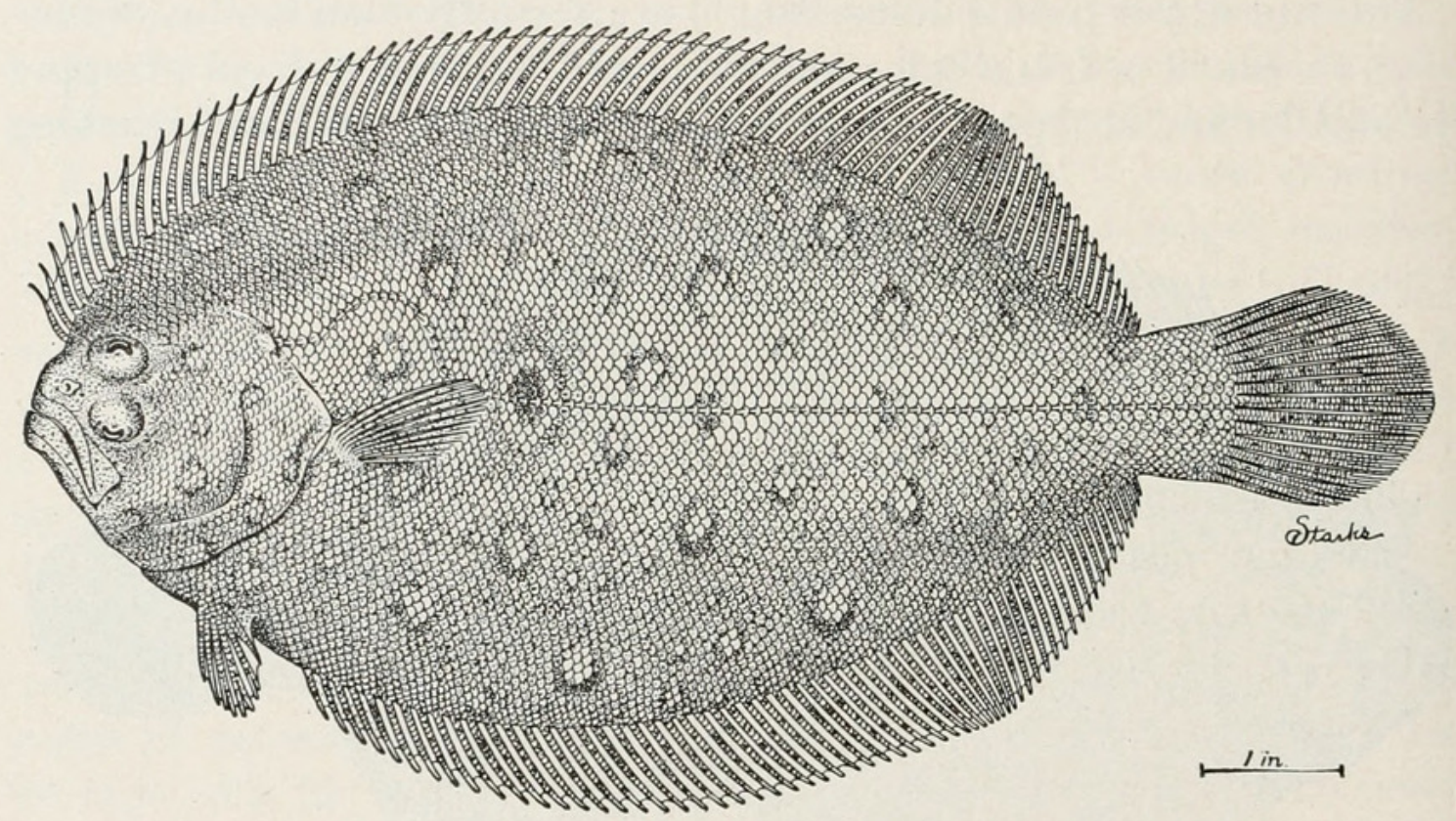

Fig. 5.-Pseudorhombus misakius. (Misaki.)

Color brown, indefinitely mottled with darker brown; vertical fins flecked and spotted with brown; a dark spot at tip of pectoral more or less definitely ocellated, with light brown or white.

The above description is of the type, $25 \mathrm{~cm}$. in length. Other specimens vary as follows: Dorsal from 79 to 86 ; anal 61 to 67 ; pores of lateral line 79 to 85 .

Of this species we have numerous specimens from Misaki, Kobe, Tsuruga, and Wakanoura. The type is from Kobe and is numbered 55643 U.S.N.M. Others are No. 9823, Stanford University.

This is one of the common Japanese flounders, but it appears thus far to have escaped notice, unless Pseudorhombus oligodon proves to be the same species.

(Misaki, mi, red; saki, point; one of the best known of Japanese fishing villages, the location of the marine zoological station of the Imperial University of Tokyo.) 


\section{PSEUDORHOMBUS OLIGODON (Bleeker).}

Rhombus oligodon Bleeker, Verh. Bat. Gen., XXVI, 1857, Nieuw, Nalez, Japan, p. 121 (Nagasaki); Natuur. Tyds. Nederl., VI, p. 419; Act Soc. Sci. Ind. Ned., V, Japan, pl. III, fig. 2.

Pseudorhombus oligodon Jordan and Evermann, Proc. U. S. Nat. Mus., 1902, XXV, p. 365 (Formosa); (scales of blind side ctenoid; gillrakers $\mathrm{x}+11$. A. 57 ; scales 78 ).

Habitat.-Nagasaki to Formosa.

Head, $3 \frac{1}{2}$ in length to base of caudal; depth, $2 \frac{1}{10}$; eye, $4 \frac{1}{6}$ in head; snout, to edge of upper eye, $4 \frac{1}{2}$; maxillary, $2 \frac{1}{5}$; dorsal, 78 ; anal 62 ; scales, 74 .

Upper eye slightly anterior to lower; interorbital space very narrow; maxillary reaching to opposite posterior margin of lower eye or a little past; canines fewer than in related species, about 20 on each side of upper jaw; lower jaw with about 12, said to be in two rows of 6 each.

Second ray of dorsal opposite front of upper eye; pectoral bluntly pointed reaching to angle of lateial line; its length $1 \frac{3}{5}$ in head; middle rays of caudal longest, forming a slight broadly rounded angle, arch of lateral line contained $2 \frac{3}{4}$ in straight part.

Color uniform dusky on body with a dark blended blotch at angle of lateral line; pectoral without markings, other fins with small round dusky spots scattered over them.

(Here described from the plate of the type specimen published by Bleeker.)

This species we did not find in Japan. It is known to us from a specimen from Formosa.

(òiyos, few: ò ov's, tooth.)

\section{PSEUDORHOMBUS DUPLICIOCELLATUS Regan.}

Pseudorhombus dupliciocellatus Regan, Ann. Mag. Nat. Hist., 1905, p. 26 (Kobe).

Habitat.-Inland Sea of Japan.

Head, 4 in length; depth, $2 \frac{2}{7}$; eye, $4 \frac{3}{4}$ in head; dorsal, 74; anal, 56 ; scales, 98; transverse series above curve of lateral line, 18.

Snout a little shorter than eye; eyes separated by a ridge; maxillary extending to below middle of eye; gillrakers short and stout, 8 or 9 on lower part of arch; scales ctenoid on ocular side; cycloid on blind side; pectoral of ocular side three-fifths of head; of blind side twofifths; middle caudal rays longest; two-ninths of length; caudal peduncle one-half as long as deep.

Color olivaceous, with darker spots and markings and with 5 conspicuoùs ocelli or double ocelli arranged thus ::- ; fins with small dark spots. Total length $380 \mathrm{~mm}$. (Regan.)

This species is unknown to us.

(duplex, double; ocella, eye-spot.) 


\section{PSEUDORHOMBUS OCELLIFER Regan.}

?? Pseudorhombus pentophthalmus GüNTher Cat. Fish, IV, 1862, p. 428 (China). Pseudorhombus pentophthalmus GünTHER, Shore Fishes Challenger, 1880, p. 69, (Inland Sea of Japan) not of Günther, 1862, according to Regan.

Pseudorhombus russelli Oтак I, Journ. Fish Bur., 1897, p. 6 (S. E. Japan), not Platessa russelli Gray.

Pseudorhombus ocellifer a REgAn, Ann. Mag. Nat. Hist., 1905, p. 25, (Inland Sea of Japan), from Günther's specimens.

Habitat.-All coasts of southern and central Japan, north to Mororan on Voleano Bay.

Head, 3.33 in length without caudal; depth, 2; D. 71; A. 52; pores, in lateral line 68; upper eye, 5 in head; snout, 3.87; maxillary, 2; pectoral (eyed side), 1.75; blind side, 2.4; caudal, 1.33 .

Body broad and thin, ventral and dorsal outlines evenly curved; snout blunt, obliquely truncate, separated from anterior profile by a notch; eyes separated by a narrow sharp ridge which is continuous backward and upward above cheek; anterior edge of eyes about even, posterior edge of upper eye a little more posterior than that of lower; mouth much curved, the maxillary reaching to posterior edge of lower eye; teeth sharp and curved, set in a single row on each jaw, some of them very slightly arrow-shaped at tips; on blind side teeth on premaxillary grow smaller backward and disappear opposite the middle of length of maxillary; gillrakers moderately slender and long, the longest slightly exceeding half diameter of eye, $6+16$ to 18 in number. Dorsal beginning slightly toward blind side a little in front of anterior edge of upper eye, the first ray at notch separating the snout, anterior rays somewhat produced beyond the membrane; pectoral of eyed side longer than that of blind side; ventrals similar in size and position; caudal with the middle rays produced and with no lateral angles, the sides being broadly rounded. Scales ctenoid on eyed side, spinules short, sharp, and numerous; cycloid on blind side; scales on all fin rays rather large, even, and ctenoid on eyed side; lateral line strongly arched anteriorly, a branch from above gill opening running to dorsal profile above posterior edge of eye, opposite eighth ray of dorsal.

Color light brown, with dark spots nearly as large as eye, and sometimes indefinitely ocellated, scattered over the body, one at angle of

a Head, $3 \frac{2}{5}$ in length; depth 2 to $2 \frac{1}{2}$; dorsal 68 to 73 ; anal 53 to 57 .

Snout shorter than eye, the diameter of which is $3 \frac{1}{2}$ to $3 \frac{2}{3}$ in head; eye separated by a ridge; maxillary extending to below middle of eye or beyond; gillrakers longer than gill fringes, 17 or 18 on lower part of arch; scales ctenoid on ocular side, cycloid on blind side, 64 to 72 in a longitudinal series; 11 to 13 in a transverse series from dorsal to curve of lateral line; pectoral of ocular side two-thirds to three-fourths of length of head; of blind side one-half; caudal with the middle rays longest, 4 in length; caudal peduncle one-third to one-half as long as deep.

Color brownish with darker spots and markings, of which 5 ocelli arranged thus $:$. are most prominent. Fins with small dark spots. Total length $125 \mathrm{~mm}$. (Regan.) 
lateral line, three on back in a row following dorsal outline and a distance below base of dorsal equal to postorbital length of head, three on lower part of side similarly arranged and opposite those on back; fins irregularly speckled with brown.

According to Regan, this Japanese species is distinct from Pseudorhombus pentophthalmus, described by Günther, from China. It has much in common with P'seudorhombus russelli described from Canton by Gray. It seems to differ in color and also in the larger size of the mouth. Pseudorhombus arsius from the Ganges, as described by Bleeker, is different from our species, but it may be identical with Pseuhorhombus russelli.

This species resembles $P$. misakius and $P$. cinnamomens, but may be known by its fewer fin rays and by the more numerous gillrakers.

Our numerous specimens, none of them more than 8 inches long, are from Nagasaki (17), Kobe (17), Tokyo (6), Wakanoura (1), and Mororan (1).

(ocellifer, bearing eye-like spots.)

\section{ro. PSEUDORHOMBUS OLIGOLEPIS Bleeker.}

Rhombus oligolepis Bleek ER, Vifde Bijdrag Japan, 1869, p. 8, pl,-II, fig. 2, (Nagasaki) (young example).

Pseudorhombus oligolepis Günther, Cat. Fish, IV, p. 430; copied.

Habitat.-Nagasaki.

Dorsal, 66; anal, 48; lateral line, 38.

Teeth in jaws conical, small subequal, more than 30 on each side of upper jaw and about 16 on the lower; height of the body two-fifths of total length; eyes very close together, the upper being scarcely in advance of the lower; lateral line with a strong curve anteriorly; scales ciliated; pectoral a little shorter than head. Olive, with brownish and pear colored spots. (Günther, after Bleeker.) Length, $64 \mathrm{~mm}$.

Bleeker's plate shows the dorsal to have 69 rays, the anal 47 ; pores of the lateral line, 48 ; scales about 40 ; head $3 \frac{1}{2}$ in length to base of caudal; depth, 2 ; pectoral $1 \frac{1}{2}$ in head; maxillary reaching to below front of pupil; lateral line with a small auxiliary branch.

This species is known from a small specimen obtained by Bleeker from Nagasaki. Its very large scales should apparently entitle it to generic separation from Pseudorhombus. The character, however, needs verification.

(o’íyos, few; $\lambda \varepsilon \pi i s$, scale.)

\section{PARALICHTHYS Girard.}

Paralichthys Girard, U. S. Pac. R. R. Surv., X, 1858, p. 146 (maculosus=californicus).

Uropsetta Gill, Proc. Ac. Nat. Sci. Phila., 1862, p. 330 (californicus=maculosus).

Chrnopsetta GiLL, Proc. Ac. Nat. Sci. Phila., 1864, p. 218 (ocellaris=dentatus). 
Eyes and color normally on the left side. Body oblong; mouth large, oblique; each jaw with a single row of usually slender and sharp teeth, which are more or less enlarged anteriorly; no teeth on vomer or palatines. Gillrakers slender. Scales small, weakly ctenoid or ciliated; lateral line simple, with a strong curve anteriorly and with no accessory dorsal branch. Dorsal fin beginning before the eye, its anterior rays not produced; both ventrals lateral; caudal fin double truncate, or double concave, its middle rays produced; no anal spine. Species numerous, in temperate seas. This genus, as now restricted, contains a considerable number of species, inhabiting both coasts of America and the eastern coasts of Asia.

( $\pi \alpha \rho \alpha \alpha^{\prime} \lambda \lambda_{\eta} \lambda \circ 5$, parallel; i $i \chi \theta v_{5}^{\prime}$, fish.)

$$
\text { KEY TO SPECIES. }
$$

a. Dorsal rays about 72 ; anal rays 57 ; scales $120 \ldots \ldots \ldots \ldots$............... olivaceus, 11 aa. Dorsal rays about 80 ; anal rays about 60 ; scales $110 \ldots \ldots$........... coreanicus, 12 aaa. Dorsal rays about 69 ; anal rays 51 ; scales $110 \ldots . . . \ldots . . .$. percocephalus, 13

\section{iI. PARALICHTHYS OLIVACEUS (Schlegel).}

HIRAME $a$ (HALIBUT), MAKAREI (TRUE FLOUNDER), AOBAKAREI (GREEN-LEAF FLOUNDER).

Hippoglossus olivaceus Schleger, Fauna Japonica, Poiss., 1846, p. 184, pl. xcrv, fig. 94 (Nagasaki).

Pseudorhombus olivaceus Günther, Cat. Fish, IV, 1862, p. 429 (Amoy); Shore Fishes Challenger, 1880, p. 69 (Inland Sea of Japan).-NAmrye, Class. Cat., 1881, p. 110 (Tokyo).-Oтак I, Journ. Fisheries Bureau Tokyo, 1897, p. 5, pl. v, fig. 2 (Japan).

Chrnopsetta olivacea Bleeker, Enum. Poiss. Connues du Japan, 1879, p. 21 (Nagasaki, Osaka, Yedo).

Paralichthys olivaceus Sterndachner, Reise Aurora, 1896, p. 217 (Kobe).-Jordan and Snyder, Proc. U.S. Nat. Mus., 1900, p. 379 (Tokyo, Hakodate); CheckList, 1901, p. 121 (Yokohama, Nagasaki).

Chinopsetta wolffi Bleeker, Enum. Poiss. Connues du Japan, 1879, p. 21. (Nagasaki).

Rhombus wolffi Bleeker, Japan, p. 421 (Nagasaki); Vifde Bijdrag Japan, pl. II, fig. 2 (D. $79 ;$ A. 61 ).

Habitat. - All coasts of Japan, north to Volcano Bay.

Head, $3 \frac{3}{4}$ in length to base of caudal; depth, $2 \frac{1}{2}$; eye, $7 \frac{1}{2}$ in head; interorbital space, $9 \frac{1}{2}$; snout, $4 \frac{1}{4}$; maxillary, $2 \frac{1}{8}$; dorsal, 72 ; anal, 57 ; pores of lateral line, 120.

Lower jaw truncate, nearly vertical at the tip, and strongly projecting, its posterior end forming an angle at lower outline of head; maxillary reaching to slightly past posterior margin of lower eye; gape of mouth strongly arched; teeth sharp, slender and irregular in size and position, usually covered by skin nearly to their tips, which easily slips back; snout and anterior part of maxillary naked; mandible sometimes entirely naked, usually with a small patch of scales posteriorly; interorbital space flat and rather wide, covered with fine

a hira, broad; me, eye; hirame becomes birame in composition, a matter of euphony. 
scales; lower eye very slightly posterior to upper; gillrakers rather long and slender, the longest nearly as long as diameter of eye; $6+16$ in number.

Pectorals rounded, that of eyed side reaching a little past arch of lateral line, its length 3 in head; ventral of eyed side a little nearer to abdominal ridge than that of blind side, its length equal to distance from tip of snout to middle of lower eye; origin of dorsal opposite front of upper eye; caudal double truncate.

Color brownish gray speckled with dark brown and white, the former color often arranged in rings and half rings, the white in small round spots scattered irregularly and sparsely over the body, often entirely absent, or in a single more or less definite series following the dorsal and ventral outlines; vertical fins colored like body; pectoral and ventral with irregular broken lines across the rays.

The above measurements were made from a specimen $32 \mathrm{~cm}$. in length from Hakodate.

Other specimens are from Mororan, Same, Hakodate, Misaki, Aomori, Matsushima, Tokyo, Wakanoura, Kobe, Kawatana, Onomichi, Hiroshima, and Nagasaki. It is the largest as well as the most abundant of all the Japanese flounders, the halibut excepted, every where used as food.

(olivaceus, olive-colored.)

\section{I2. PARALICHTHYS COREANICUS (Schmidt).}

Paralichthys olivaceus var. coreanicus Schмгd, Pisc. Mar. Orient, 1904, p. 230 (Gensan, Korea).

Habitat.-Korea, not known from Japan.

Dorsal rays, 80; anal rays, 60; scales, 110 (Schmidt); otherwise essentially as in Paralichthys olivaceus, from which it may not be separable.

(Coreanious, Korean).

\section{PARALICHTHYS PERCOCEPHALUS (Basilewsky).}

Platessa percocephala Basilewsky, Bull. Soc. Nat. Moscow, 1855, p. 245 (Japan Sea, Peking).

Pseudorhombus swinhonis Günther, Ann. Mag. Nat. Hist., 1873, p. 379 (Chifu, China).

Habitat.- Japan Sea, not known, on the Japanese coast.

Head $3 \frac{3}{4}$ in length without caudal; depth $2 \frac{3}{5}$; dorsal 69 ; anal 51; lateral line 110.

Jaws nearly even in front, longer than eye, which is $\frac{2}{11}$ of the head; cleft of mouth wide; length of maxillary $2 \frac{1}{3}$ in head and extending beyond eye; upper jaw with 3 pairs of canine teeth anteriorly; lower jaw with 8 or 10 strong teeth on each side; interorbital space rather flat, not so wide as vertical diameter of orbit; lower eye scarcely in 
advance of upper; gillrakers rather wide set, lanceolate, and not quite as long as eye.

Origin of dorsal opposite front of orbit; dorsal terminating at a distance from caudal equal to three-fourths of the depth of the free portion of the tail, its longest rays at posterior one-third of fin, nearly as long as pectoral, and contained $2 \frac{1}{3}$ in head; caudal subtruncate or rounded; scales ciliated; maxillary and interorbital space scaly posteriorly; fin rays scaly.

Color brownish gray; head, body, and pectoral fins sprinkled over with brown dots. (Günther, from specimens 16 inches in length from Chifu (Chefoo), China.)

This species is not known to us.

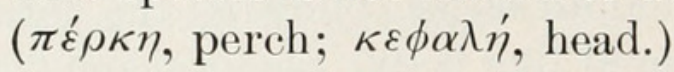

6. XYSTRIAS Jordan and Starks.

Xystrias Jordan and Starks, Bull. U. S. Fish Com., XXII, 1902 (1904), p. 623 (grigorjewi).

Form of Hippoglossoides.-Eyes and color on the right side. Lateral line with a low arch in front; mouth rather large; the teeth rather small, in two rows; gillrakers long and slender; scales of eyed side finely ctenoid, those of blind side smooth. One species, a large flounder of Japan.

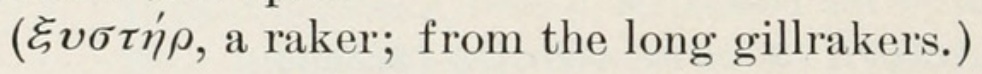

14. XYSTRIAS GRIGORJEWI (Herzenstein).

MIZUKAREI (WATER FLOUNDER).

Hippoglossus grigorjewi Henzenstern, Bull. Ac. Sci. Imp. Petersb., 1890, p. 134 (Hakodate).

Xystrias grigorjewi Jordan and Stanks, Bull. U. S. Fish Comm., XXII, 1902 (1904), p. 624 (Suruga Bay).

Hippoglossoides sp. Отак I, Journ. Fisheries Bureau, 1897, p. 2, pl. v, fig. 1 (Southeastern Japan).

Verasper otakii Jokdan and SNyder, Proc. U. S. Nat. Mus., 1900, p. 378 (Tokyo from Otaki's specimen); Check-List, p. 121, 1901.

Head, $3 \frac{4}{5}$ in length; depth, $2 \frac{1}{3}$; dorsal, 86; anal, 68; scales, 92 , on blind side, 98 ; lower orbit, 4 in head; snout, $5 \frac{1}{2}$; maxillary, $2 \frac{1}{2}$; width of interorbital space, 6 in diameter of eye; height of longest dorsal rays, $2 \frac{2}{3}$ in head; anal rays, $2 \frac{2}{3}$; rays of right pectoral, $1 \frac{4}{5}$; ventral, $3 \frac{1}{2}$; pectoral, 11.

Body dextral, dorsal outline a little more convex than ventral. Mouth wide, oblique; outline of gape strongly curved; maxillary reaching a vertical from posterior edge of pupil; symphyseal knob small. Teeth of both jaws small, growing larger anteriorly, those of upper jaw in two series, the inner ones small, the outer larger and canine-like; teeth of lower jaw in a single series; gillrakers $6+17$, rather 
slender, length of longest 4 in maxillary; anterior nostril with a dermal flap which extends to posterior edge of second nostril; anterior margins of eyes opposite each other; interorbital space narrow, convex; lateral line arched above pectoral, the width of arch equal to length of pectoral; right side of body and head, except snout, lower jaw, and a small space near vent, covered with small, strongly ctenoid scales; left side of body with smooth scales; on both sides of body are small, elongate scales wedged in between the larger ones; rays of dorsal, anal, and caudal fins with small scales; posterior edge of maxillary with a few small scales; dorsal fin beginning over anterior edge of pupil, each ray with a small, projecting filament; anal with a naked spine at its insertion, rays with filaments; dorsal and anal ending

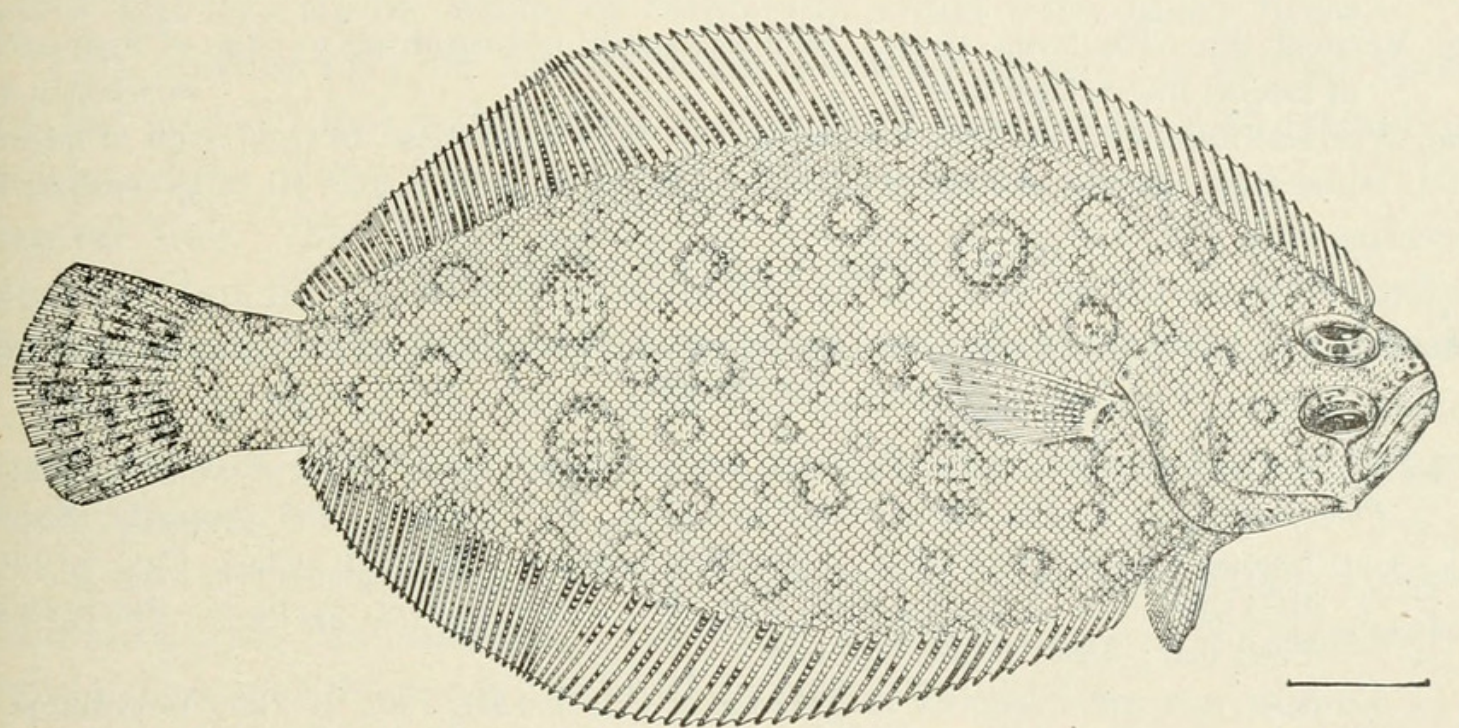

Fig. 6.-XYSTRIAS GRIGORJEWI.

opposite each other; edge of caudal bluntly angular; upper rays of right pectoral longest; pectoral of blind side shorter, its length contained $2 \frac{1}{3}$ in head, its middle rays longest. Color in alcohol, brownish; head with an indistinct dark spot just below angle of preopercie; two similar spots on a line behind upper eye; body with 6 welldefined dark spots with indistinct light markings, arranged 3 above and 3 below lateral line; of the anterior pair, the upper is a little in advance of the lower one, others opposite each other; 2 indefinite spots above the lateral line, just posterior to angle of opercle; fins without spots; snout on blind side with a transverse black blotch, which is continued on the lower jaw.

Of this common species we have specimens from Hakodate, Matsushima, Aomori, and Tokyo. Mr. Masao Nakamura sends a photograph of a specimen from Uzen in Echigo.

(Named for Professor Grigorjew.) 


\section{VERASPER Jordan and Gilbert.}

Verasper Jordan and Gilbert, Report Fur Seal Invest., III, 1899, p. 490, (moseri).

Body dextral; dorsal inserted above the front of pupil; lateral line strongly arched above the root of the pectoral, without recurrent dorsal branch; scales firm, extremely spinous. Mouth large; upper teeth in 2 series, teeth uniformly small, without canines. Gillrakers short, thick, and triangular, few in number; none of the fin rays notably produced or exserted.

(verus, true; asper, rough, the word being suggested by Veratrum.) KEY TO SPECIES.

a. Vertical fins with large, round, blended spots, not reaching to edge of fins; arch of lateral line rather low . . . . . . . . . . . . . . . . . . . . . variegatus, 15

aa. Vertical fins, with streaks following the rays from base to tips; arch of lateral line more abrupt and higher . . . . . . . . . . . . . . . . . . . . moseri, 16

15. VERASPER VARIEGATUS (Schlegel).

HOSHIGAREI (STAR-FLOUNDER); ISHIAMATE (ROCK-FLOUNDER); MEDAKAKAREI (BAMBOOFLOUNDER).

Platessa variegata Schlegel, Fauna Japonica, Poiss., 1846, p. 176, pl. xc (Nagasaki). Pleuronectes variegatus Günther, Cat. Fish., IV, 1862, p. 453 (copied); Shore Fishes Challenger, 1880, p. 69 (Yokohama).-Namiye, Class. Cat., p. 110, 1881 (Tokyo).—Otaki, Journ. Fish. Bur., 1897, p. 7, pl.vir, fig. 9.—Ishiкawa, Prel. Cat., 1897, p. 25 (Tokyo).

Verasper variegatus JoRdAn and SNYDER, Check-List, 1901, p. 120 (Yokohama); Proc. U. S. Nat. Mus., 1901, p. 378 (Tokyo).

\section{Mabitat.- Southern Japan, north to Matsushima Bay.}

Head, $3 \frac{1}{3}$ in length to base of caudal; depth, $2 \frac{1}{10}$; eye, 6 in head; maxillary, 3 ; snout, $5 \frac{1}{2}$; dorsal, 80 ; anal, 61 ; pores in lateral line, 95 .

Mouth oblique, the gape strongly arched; maxillary reaching to below posterior edge of pupil; lower jaw strongly projecting; posterior end of mandible forming a slight angle at lower outline of head; teeth in two series in upper jaw, in 1 on side of lower jaw and in 2 in front; posterior margins of eyes opposite; interorbital space slightly convex, covered with rough scales; its width equal to diameter of pupil; gillrakers flat and short, 6 of them on lower limb of arch.

Arch of lateral line rather low and followed by a wavy portion, before it becomes straight posteriorly; height of curve, three-fifths diameter of eye; length of curve, $2 \frac{1}{2}$ to $2 \frac{4}{5}$ in head; scales everywhere very rough on eyed side, cycloid on blind side except an area along middle of body anteriorly, where they are rather rough by reason of a few small spinules on each scale, or in many instances a single spinule.

Dorsal beginning above front of pupil of upper eye; pectoral rounded at tip, that of eyed side, 2 in head, the other $2 \frac{1}{4}$; ventrals 
even on both sides, $3 \frac{1}{5}$ in head; caudal broadly rounded, not angulated at tips of outer rays.

Body uniformly dark brown; dorsal with 6 or 7 , and anal 5 or 6 , large black or dark-brown spots with blended edges, the largest covering 3 or 4 rays; these nearly round near the base of the fins and not reaching the outer edge of the fin; usually 1 or 2 other spots irregularly placed opposite the interspaces and nearer edge of fin; caudal with 2 or 3 similar but smaller spots irregularly placed; blind side of body posterior to pectoral irregularly spotted with dark brown, the spots usually round, and as large, or sometimes larger than, the pupil, these present in all of our larger specimens and absent in the smaller ones up to 5 or 6 inches in length, except in one example, where they show faintly; tip of caudal of blind side soiled with dusky brown.

This species may be known from Verasper moseri by having spots on the vertical fins rather than well-defined regular streaks extending to the edges of the fins and by the higher, more abrupt arch of the lateral line. The blind side of $V$. moseri is sometimes irregularly spotted, but never, in our specimens, so thickly or so conspicuously. In both species the blind side is largely rusty red in life.

The spots on the fins shown in Schlegel's plate ${ }^{a}$ of Verasper variegatus are not nearly so large as in our specimens, but they are similarly placed.

Of this common species we have specimens from Yokohama, Tokyo, Onomichi, and Matsushima. Its range is almost exclusively southerly, while Verasper moseri is confined to northern Japan.

(variegatus, varied.)

I6. VERASPER MOSERI Jordan and Gilbert.

Verasper moseri Jordan and GILBert, Rept. Fur Seal Invest., III, 1898, pl. Lxxxv, (Shana Bay, Iturup Island, Kuril Group.) (Type, No. 48797. Coll. Albatross, Capt. J. F. Moser. -Jordan and Evermann, Fish North Mid. Amer., 1898, III, p. 2619 (Iturup).-Jordan and SNyder, Check-List, 1901, p. 121 (Iturup, Hakodate) ; Proc. U. S. Nat. Mus., 1901, p. 378 (Iturup, Hakodate).Schmid, Faune Mer. Och. Jap., 1903, p. 19 (Ochotsk Sea).

Habitat.-Northern Japan, south to Aomori.

Head, $3 \frac{1}{3}$ in length to base of caudal; depth, 2; D. 82; A. 58; pectoral, 12 ; pores in lateral line, 84 ; depth of caudal peduncle 4 in greatest depth of body; length of caudal peduncle, measured axially, $1 \frac{2}{3}$ in its depth. Head much depressed, with rather wide, flat interorbital space, its thickness at interorbital space equaling distance between pupils of upper and lower eyes. Mouth small, very oblique, the gape strongly arched, the broad maxillary reaching a vertical behind middle of pupil, $2 \frac{4}{5}$ in head; mandible narrowing toward tip, with very rudimentary symphyseal knob. Teeth in upper jaw in two distinct series 
throughout, those of the outer series increasing slight $y$ in size toward front of jaw, but none of them canine-like; mandibular teeth in one row, except at symphysis, where a few teeth form a short outer series. Nasal openings of eyed side approximated in front of middle of interorbital space, the anterior with a short tube, the posterior with a raised rim. Eyes small, their anterior margins opposite, the diameter of lower eye equaling distance from tip of snout to posterior nostril, $6 \frac{1}{3}$ in head. Interorbital space rather broad and flat, not ridge-like, its total width equaling $\frac{1}{2}$ diameter or orbit. Gillrakers short, broad, triangular, minutely toothed on inner margin, one-third diameter of eye; 7 present on horizontal limb of outer arch. Lateral line with a short high anterior arch, the cord of which is one-fifth the straight portion; height of arch one-third its length; behind the arch lateral line descending in a gentle curve to middle of sides, the scales

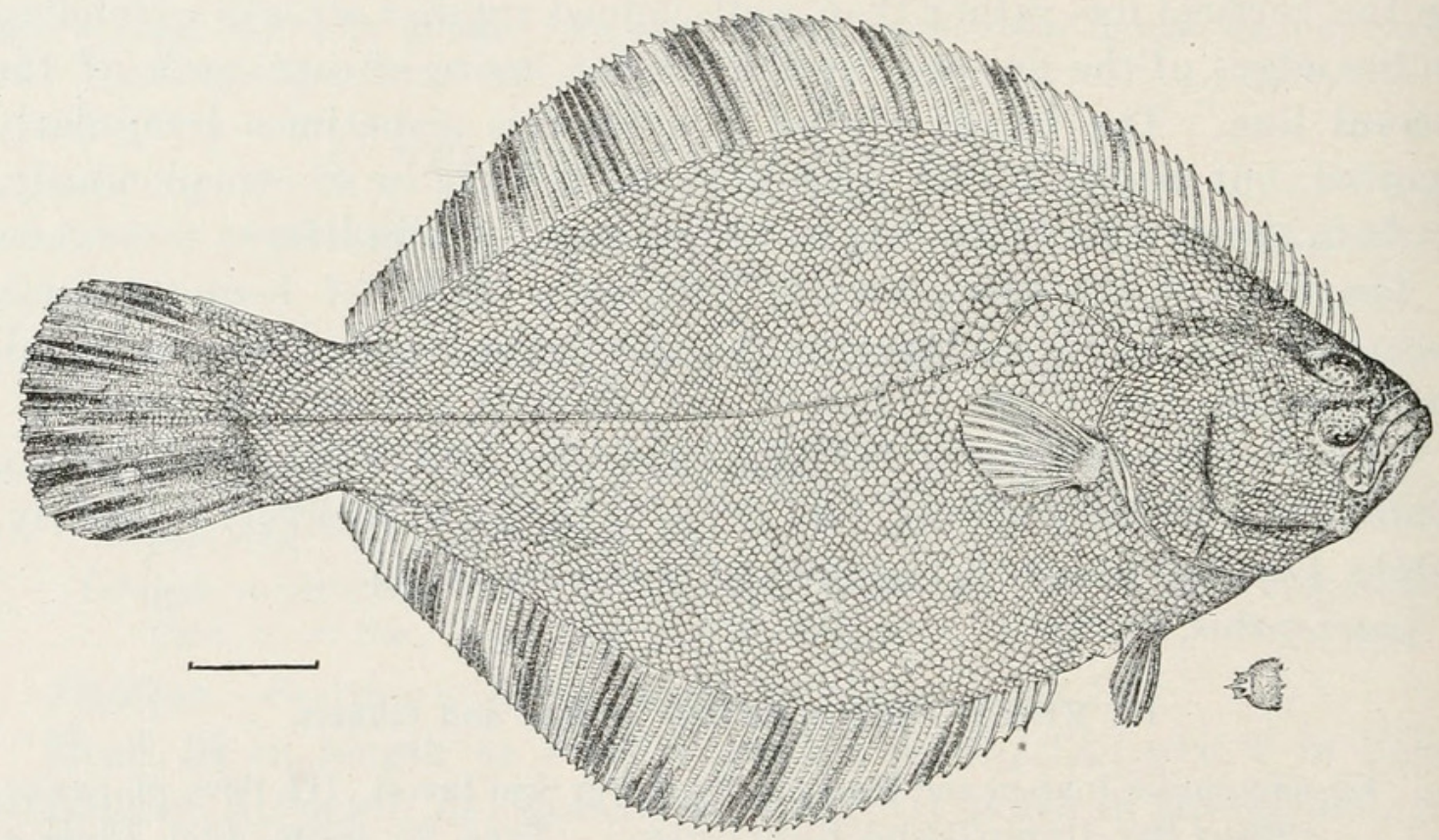

Fug. 7.-VERASPER Moseri.

very rough, each possessing several long, sharp spines diverging from median portion of posterior margin; anterior and posterior portions of dorsal and anal fins naked, the rays of the middle portion each with a series of strongly ctenoid scales; caudal densely scaled to tip; pectorals and ventrals naked; head covered with strongly spinous scales, excepting snout, maxillary, and mandible; on blind side of head the snout, jaws, preopercle, subopercle, lower half of opercle, and all but a central strip on interopercle, scaleless; on blind side the scales are rough on head, ventral area, and along bases of ventral fins, largely smooth elsewhere. Dorsal beginning above front of pupil, the rays increasing in length to the forty-fifth, which is $2 \frac{2}{7}$ in head; longest anal ray (the seventeenth) $2 \frac{1}{7}$ in head. Caudal broadly rounded, $1 \frac{2}{5}$ in head; pectoral short and broad, $2 \frac{2}{5}$ in head; ventrals of nearly equal length, reaching origin of anal, $3 \frac{1}{5}$ in head; no anal spine. Color in 
spirits, centers of the scales light gray, the margins dark brown; fins light or dusky, the vertical fins with conspicuous black bars, parallel with the rays, these most evident on under side where the pigment seems principally to occur, and are seen through the fin more faintly on the colored side; lining of cheeks and gill cover of colored side dusky; peritoneum gray.

Of this species, we have specimens from Mororan, Hakodate, Same, and Iturup Island. It is common in northern Japan, its range nowhere meeting that of Verasper variegatus.

(Named for Jefferson Franklin Moser, U. S. Navy, lieutenant-commander, in charge of the U. S. Bureau of Fisheries steamer Albatross, and a member of the United States Fur Seal Commission for 1896.)

\section{ACANTHOPSETTA Schmidt.}

Acanthopsetta Schmidt, Faune Mer. Och., 1903, p. 19; name only (nadeshnyi).

This genus is allied to Verasper: Mouth large, teeth small, in one row; lateral line with a long low arch in front; scales moderate, ctenoid; interorbital space scaled; anal spine strong; dorsal rays about 75 ; anal rays about 60 ; caudal fin rounded. Ochotsk Sea.

( $\not \kappa \alpha \nu \curvearrowright \alpha$, spine; $\psi \hat{\eta} \tau \tau \alpha$, flounder.)

\section{ACANTHOPSETTA NADESHNYI Schmidt.}

anthopsetta nadeshnyi Scnмmit, Faune Mer. Ochotsk, Japan, 1903, p. 19, (Japan Sea, Vladivostook, mouth of Amur, etc.); name only; Pisc. Orient., Mar. 1904, p. 237, pl. v, fig. 1 (Vladivostok, Aneva, Askuld, Khaliz, mouth of Amur, Broughton Gulf, Paratondra, etc.)

Habitat.--Sea of Ochotsk.

Head, $3 \frac{1}{2}$ in length to caudal base; depth, $2 \frac{1}{4}$; eye, $4 \frac{3}{4}$ in head; snout to upper eye, 5; maxillary, $2 \frac{3}{5}$; dorsal, 74 ; anal, 58; pores in lateral line to base of caudal, 69 .

Upper eye very slightly posterior to lower; maxillary reaching past anterior edge of eye, scarcely to pupil; interorbital space narrow and rounded, covered with small scales; its width less than half the diameter of pupil.

Origin of dorsal above micdle of upper eye; longest dorsal rays $2 \frac{1}{10}$ in head; pectoral broadly rounded, its 'ength $1 \frac{4}{5}$ ir head; caudal rounded, equal in length to head; lateral line with a lo., arch in front contained 3 times in straight part. Uniform dusky without markings; dorsal and anal a little lighter than the body.

The species is unknown to us. It is here described from the plate published by Schmidt.

( Vadeshnyi, a personal name.) 


\section{CYNOPSETTA Schmidt.}

Cynopselta Schмidt, Faune Mer. Ochotsk, Jap., 1903, p. 19, name only (dubia).

This genus is allied to Hippoglossoides, differing in the presence of canine teeth, 4 in the front of the lower jaw and some above. Eyes dextral. The genus has never been defined, and in a later paper, Schmidt merges it in Hippoglossoides, from which it is apparently separable by its dentition and by the long low curve of the lateral line, which is however not properly arched.

( $\kappa \dot{v} \propto \nu, \operatorname{dog} ; \psi \tilde{\eta} \tau \tau \alpha$, flounder.)

\section{I8. CYNOPSETTA DUBIA Schmidt.}

\section{ABURAGARAEI (FAT-FLOUNDER).}

Cynopsetta dubia Sснмпрт, Faune Mer. Ochotsk, Jap., 1903, p. 19 (Japan Sea, Ochotsk Sea), no description.

Hippoglossoides dubius Sснмгdт, Pisc. Mar. Orient, 1904, p. 227, pl. vi, fig. I (Mayka and Gulf of Aniva; Sea of Ochotsk).

? Hippoglossoides sp. Oтак , Journ. Fish. Bur., 1897, p. 5 (S. W. coast of Japan) (D. 79 to 87 ; A. 58 to 64 ; scales 88 ).

Mabitat. -Ochotsk Sea, south to Northern Japan, not seen by us. Head, $3 \frac{1}{2}$ in length to base of caudal; depth, $2 \frac{1}{2}$; eye, $6 \frac{1}{2}$ in head; maxillary, $2 \frac{1}{3}$; snout to upper eye, 5; dorsal, 87; anal, 65 ; scales, 88.

Eyes about opposite each other or the upper very slightly behind the lower; separated by a very narrow space which is scaled posteriorly; mouth undulating, the mandible turned up at the tip, concave behind the tip, convex at the middle, and slightly concave behind the middle; teeth rather large and unequal; maxillary reaching to posterior edge of pupil; anterior nostril ending in a tube.

Origin of dorsal opposite front of eye; longest dorsal rays equal to those of anal; $2 \frac{4}{5}$ times in head; pectoral short and rounded, $2 \frac{1}{5}$ in head; caudal broadly rounded.

Color everywhere uniform dusky without markings except a few dark, blended, very irregular spots of darker, one above middle of anal, and 4 or 5 above anterior part of lateral line.

Here described from Schmidt's plate, except for the number of scales, which is given as 88 by him. The plate shows 75 pores in the lateral line and over a hundred transverse series.

(dubius, doubtful.)

\section{HIPPOGLOSSOIDES Gottsche.}

Hippoglossoides Goтtsche, Archiv fur Naturgesch., 1835, p. 164 ("limanda"= platessoides).

Citharus Reinhardt, Kong. Dansk. Vid. Selsk., 1838, p. 116 (platessoides); not Citharus BleEk ER, 1862.

Drepanopsetta Gill, Cat. Fish. East Coast N. A., 1861, p. 50 (platessoides).

Pomatopsetta GrLl, Proc. Ac. Nat. Sci. Phila., 1864, p. 217 ("dentata"=platessoides), 
Eyes and color on the right side (except sometimes in $H$. elassodon). Body oblong, moderately compressed; mouth rather large, with 1 row of sharp teeth on each jaw; no teeth on vomer or palatines; gillrakers rather long and slender; scales ctenoid; lateral line nearly straight, simple; dorsal fin low in front, beginning over or before the eye; ventrals both latter; caudal double truncate, produced behind. This genus, as here restricted, contains 3 closely related species, 2 of the North Pacific, 1 of the North Altantic. All are essentially aretic species inhabiting shallow waters in the regions where they are most abundant.

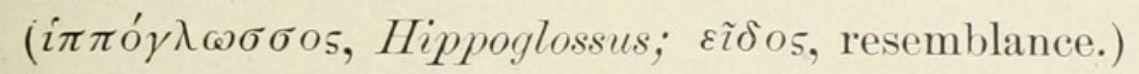

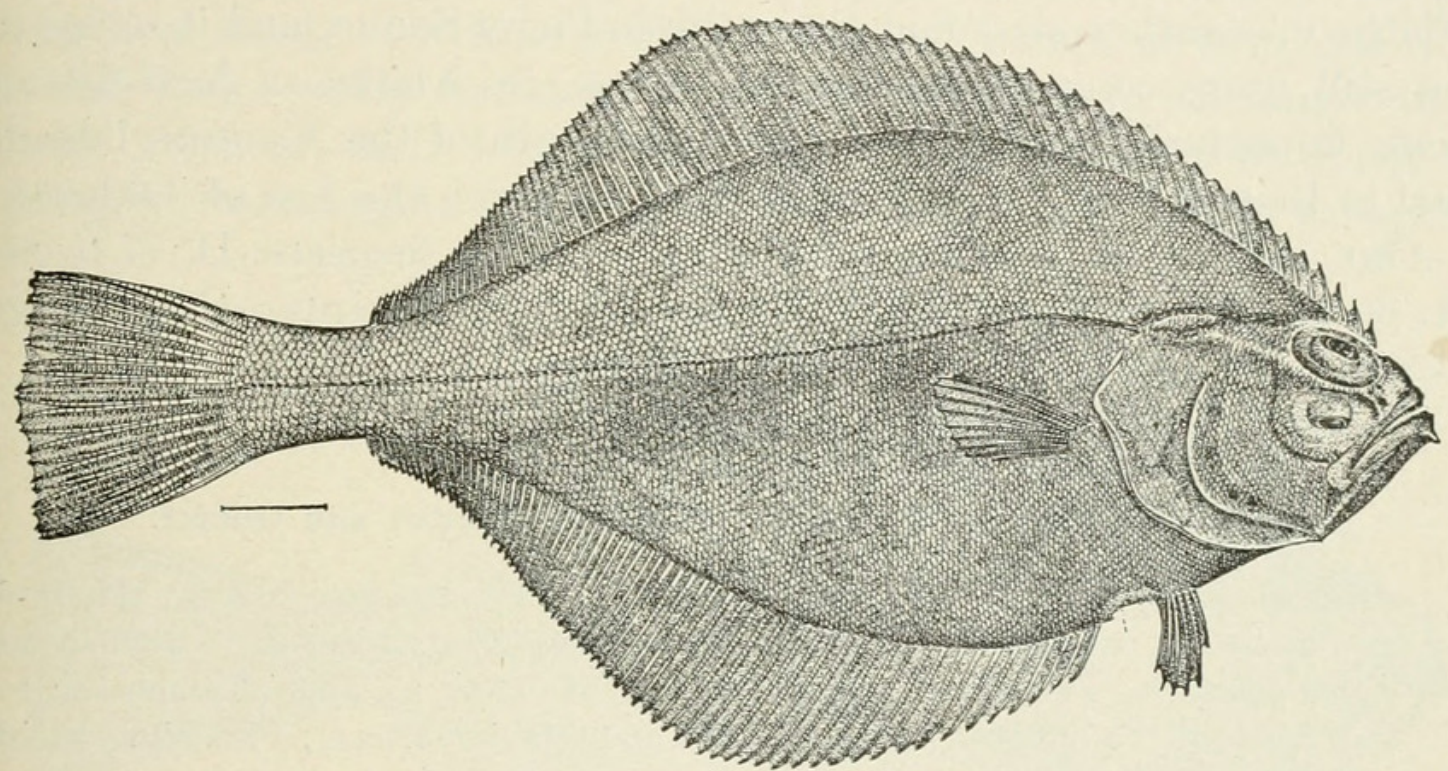

Fig. 8.-HiPPOGLOSSOIDES ELASSODON.

KEY TO SPECIES.

a. D. 80: A 63: Seales 100: interorbital space narrow, naked..........elassodon. 19 aa. D. 72: A. 56: Scales 91: interorbital space with two rows of scales.

hamiltoni. 20

19. HIPPOGLOSSOIDES ELASSODON Jordan and Gilbert.

Hippoglossoides elassodon Jordan and Gilbert, Proc. U. S. Nat. Mus., 1880, p. 278 (Seattle, Tacoma), Proc. U. S. Nat. Mus., 1880, p. 454.-Bean, Proc. U. S. Nat. Mus., 1883, p. 20. (Alaska).-Jordan and Gilbert, Rept. Fur Seal Invest., III, p. 1899, p. 489 (Bering Sea, Kamchatka).-Jordan and EverMann, Fish North Mid. Amer., III, 1898, p. 2615, pl. ccclxxiI, fig. 920 (Seattle, Bering Sea, Kamchatka)._-Аснмпрт, Pisc. Mar. Orient, 1904, p. 226 (Rimnik and Terpienia, Okhotsk Sea).

Habitat.-Bering Sea, Okhotsk Sea, south to Puget Sound.

Head, $3 \frac{1}{2}$; depth, $2 \frac{1}{2}$; eye, 4 in head; D. 77 to 87 ; A. 59 to 67 ; V. 6 ; scales, 45-100-40. Body, oblong-elliptical; caudal peduncle about as long as deep; upper profile of head continuous with the outline of back; depression over eye slight; mouih rather large, the gape curved, considerably wider on the blind side; lower jaw projecting, with a symphyseal knob; maxillary narrow, reaching beyond middle of pupil, $2 \frac{1}{2}$ head; teeth small, close set, nearly uniform, in a single row. 
Gillrakers slender, smooth, 14 to 16 below arch, the longest nearly onehalf diameter of orbit. Eyes large, separated by a narrow, knife-like ridge, which is naked, or with a single series of scales. Scales small, firm, rough, those on tail roughest, those on blind side similar, mostly smooth anteriorly. Lateral line rising anteriorly, but without arch; dorsal beginning immediately in front of pupil; anal preceded by a spine; caudal long; pectoral of eyed side one-half length of head; ventral reaching past front of anal; pectoral and ventral of eyed side with prickle-like scales. Brownish, nearly uniform, sometimes spotted with darker; fins grayish, irregularly blotched with dusky. Body sometimes sinistral. Length, 18 inches. Bering Sea south to Cape Flattery; a rather abundant shore fish in Puget Sound, and it seems to be still more common northward, being, in Alaska, a food-fish of some importance. Abundant north and south of the Aleutian Islands and in Bristol Bay. Recorded by Schmidt from the Sea of Okhotsk.

Our specimens from Kamchatka agree in all respects; D. 77 to 84; A. 60 or 61 . Pectoral not quite one-half head. Interorbital ridge sharp, with 1 series of scales; gillrakers $x+14$.



20. HIPPOGLOSSOIDES HAMILTONI Jordan and Gilbert.

Hippoglossoides hamiltoni Jordan and GLbert, Rept. Fur Seal Invest., III, 1899, p. 489, pl. LxxxIv (Dalnoi Point, Kamchatka) (Coll. Albatross).-Jordan and Evermann, Fish. North Mid. Amer., III, 1898, p. 2611 (Kamchatka).Sснмпт, Faune Mer. Jap. Och., 1903, p. 19 (Okhotsk Sea); Pisc. Mar. Orient, 1904, p. 226 (Terpienia, Okhotsk Sea).

\section{Mabitat. - Okhotsk Sea.}

Head, $3 \frac{1}{5}$ in length; depth, $2 \frac{2}{5}$; longest diameter of upper eye, $3 \frac{1}{2}$ in head; snout (measured from upper eye) 5 in head; maxillary of colored side, $2 \frac{1}{3}$, of blind side, $2 \frac{1}{6}$, in head; depth of caudal peduncle equaling its lengtl, $3 \frac{1}{3}$ in head; D. 72 ; A. 56; P. 11; pores in lateral line 91. Upper profile of head continuing the dorsal curve without interruption, there being a slight depression above the eye and an increased convexity un the snout; mandible very heavy, projecting anteriorly, so that its symphyseal profile completes the curve of the snout; a very short prominence at symphysis directed vertically downward; gape strongly curved and the mouth narrowed anteriorly, so that the maxillary and premaxillary are almost wholly concealed along the middle of their length by the overarching prefrontal; teeth acute, in a single series in each jaw, all except the anterior teeth in each jaw short; at the symphysis of lower jaw the teeth are longer and directed inward, while in the anterior end of each premaxillary the teeth are still more enlarged, and the series on each side describes a strong curve with its convex side toward the median line; maxillary reaching vertical from slightly behind middle of lower eye; nostril tubes conspicuous, the anterior in closest proximity to the upper lip, which it entirely over- 
hangs; posterior nostril tube wider and slightly shorter; eyes of nearly equal size, and opposite, separated by a wider ridge than in $H$. elassodon, the ridge bearing in its narrowest portion 2 well-defined rows of strongly spinous scales; a conspicuous series of pores joining lateral line with upper margin of upper eye, and another encircling the lower eye below and behind; a third series along mandible and preopercle; 1 large pore above posterior nostril; gillrakers slender, unarmed, 2 above the angle, 11 or 12 below it, the longest $2 \frac{3}{4}$ in eye; dorsal fin beginning above front of pupil, the longest ray $2 \frac{5}{6}$ in head; anal preceded by a strong spine, its height equaling that of dorsal; pectoral very long and slender, $\frac{2}{3}$ length of head, that of blind side shorter, $\frac{1}{2}$ length of head; ventrals reaching to base of fourth or fifth anal ray, caudal long, evenly rounded behind, the middle rays not longer than those adjacent, their length equaling distance from tip of snout to preopercular margin; scales on colored side strongly ctenoid except in

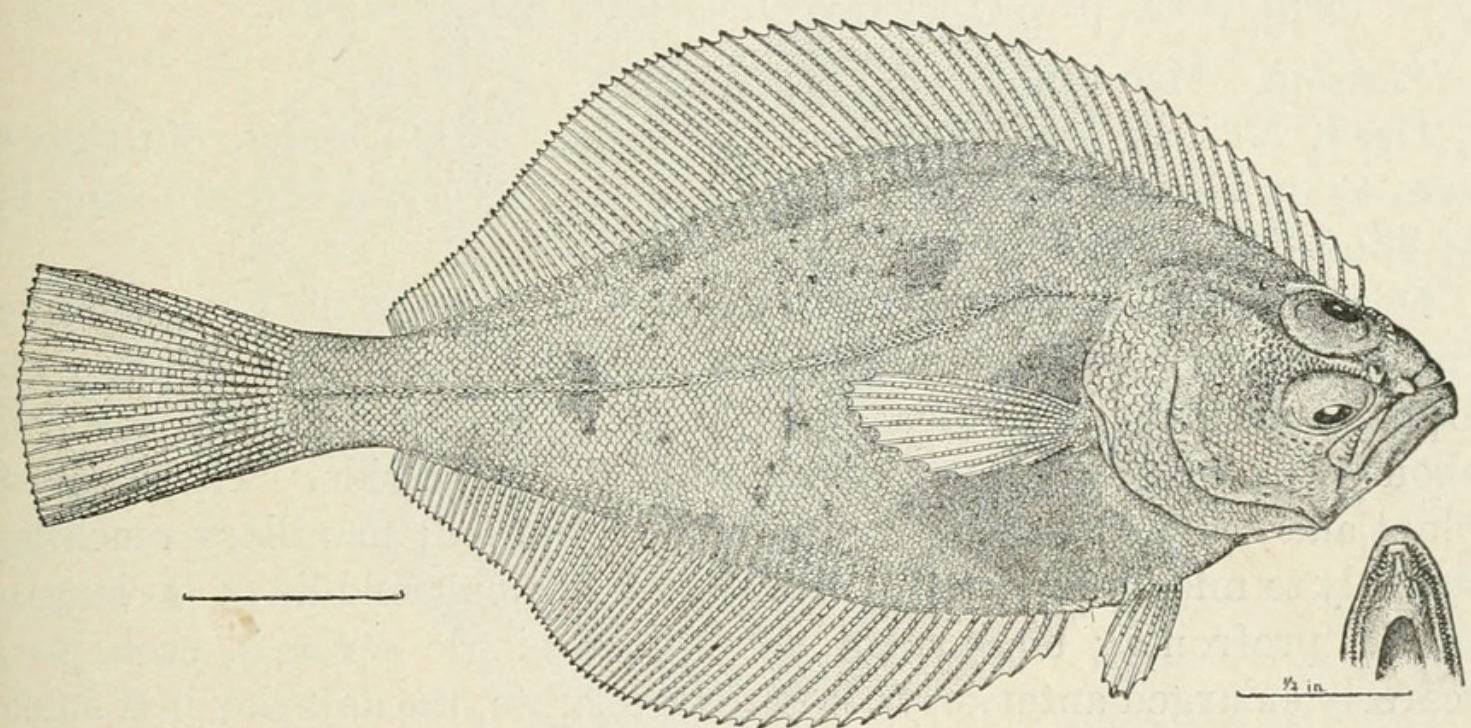

Fig. 9.-Hippoglossoides HAMILTONI.

a strip along middle of sides anteriorly; elsewhere each scale provided with 2 to 4 long spines; on blind side they are smooth except on nape and caudal peduncle; cheeks, opercles, and interorbital space covered with larger, rougher scales than those on sides; mandible and snout naked; a single series surrounding each eye anteriorly, and 1 on maxillary or colored side; blind side of head with maxillary naked; cheeks covered with minute smooth thin scales, the opercles with a few scattered spinous scales, the preopercle naked. Color nearly uniform brownish, without distinctive markings on body or fins.

The type is $17 \mathrm{~cm}$. long, from off Dalnoi Point, Kamchatka; depth, 16 fathoms. It is also recorded from the sea of Okhotsk.

(Named for Gerald Edwin H. Barrett-Hamilton, of Dublin, member of the British Commission of Fur Seal Investigation, 1896 and 1897, who made valuable collections of Kamchatkan fishes.)

Proc. N. M. vol. $\mathrm{x} \times \mathrm{xi}-06-13$ 


\section{CLEISTHENES Jordan and Starks.}

Cleisthenes Jordan and Starks, Bull. U. S. Fish Com., XXII, 1902 (1904), p. 622 (pinetorum).

This genus is closely allied to Hippoglossoides, differing in having cycloid scales everywhere in the young, and an increased number of gillrakers. The adult has a single row of ctenoid scales along anterior base of dorsal and anal, a few on snout on ridge behind interorbital space, and on opercle. The dorsal begins at the orbital rim slightly on the blind side. Eyes and color on right side. Teeth in a single row.

(Cleisthenes, the effeminate, an Athenian noted by Aristophanes.)

\section{CLEISTHENES PINETORUM Jordan and Starks.}

Cleisthenes pinetorum Jordan and Starks, Bull. U. S. Fish Com., XXII, 1902 (1904), p. 622, plate (Kinkwazan Island, Bay of Matsushima).

Habitat.-Matsushima, in deep water.

Head, 3.66 in length; depth, 2.6; D. 76; A. 56; scales, 80; upper eye, 4.6 in head; snout from upper eye, 4.6 ; pectoral of eyed side, 2 ; of blind side, 2.5 ; ventral, 3 ; caudal, 1.4 .

Dorsal outline of anterior part of body and head an even concave curve to near tip of snout, broken only by protruding upper eye. Upper eye cutting into profile, and ranging nearly vertically upward, about two-fifths of it being visible from the blind side. Tip of snout blunt and rounded; mouth rather strongly curved; maxillary reaching scarcely to middle of lower eye, not covered along middle of its length by the prefrontal; teeth small, acute, in a single series in each jaw, scarcely enlarged anteriorly; nostrils moderate, the anterior in a short tube which does not reach to edge of preorbital; preorbital with a blunt spine on anterior edge; eyes about equal in size, separated by a flat interspace, covered with cycloid scales; gillrakers slender, equal to half the eye in length, 8 to 10 above and 24 to 27 below the angle.

Dorsal fin beginning slightly on blind side at edge of orbit opposite posterior margin of pupil; anal preceded by a strong spine; ventrals not reaching to anal (reaching to base of second anal ray in young); caudal evenly rounded behind; scales everywhere cycloid and with concentric rings in specimens 4 or 5 inches long.

A specimen 10 inches long has cycloid scales except a single row of ctenoid scales along base of dorsal and anal anteriorly, a few in front and behind the interorbital space, and some on opercles. The type (8.5 inches long) has only an occasional ctenoid scale along base of dorsal and anal, and the ctenoid scales on head are very sparse. A specimen 7 inches long has only a few ctenoid scales remaining on head behind interorbital space. 
Color every where dark brown, dorsal and anal a little lighter at base of rays; membrane of caudal darker than the rays making longitudinal streaks; dorsal, anal, and caudal of blind side dark toward tips of rays.

Numerous specimens were dredged off Kinkwazan Island, Matsushima Bay, at stations 3769 and 3770 . The type is $22 \mathrm{~cm}$. in length,

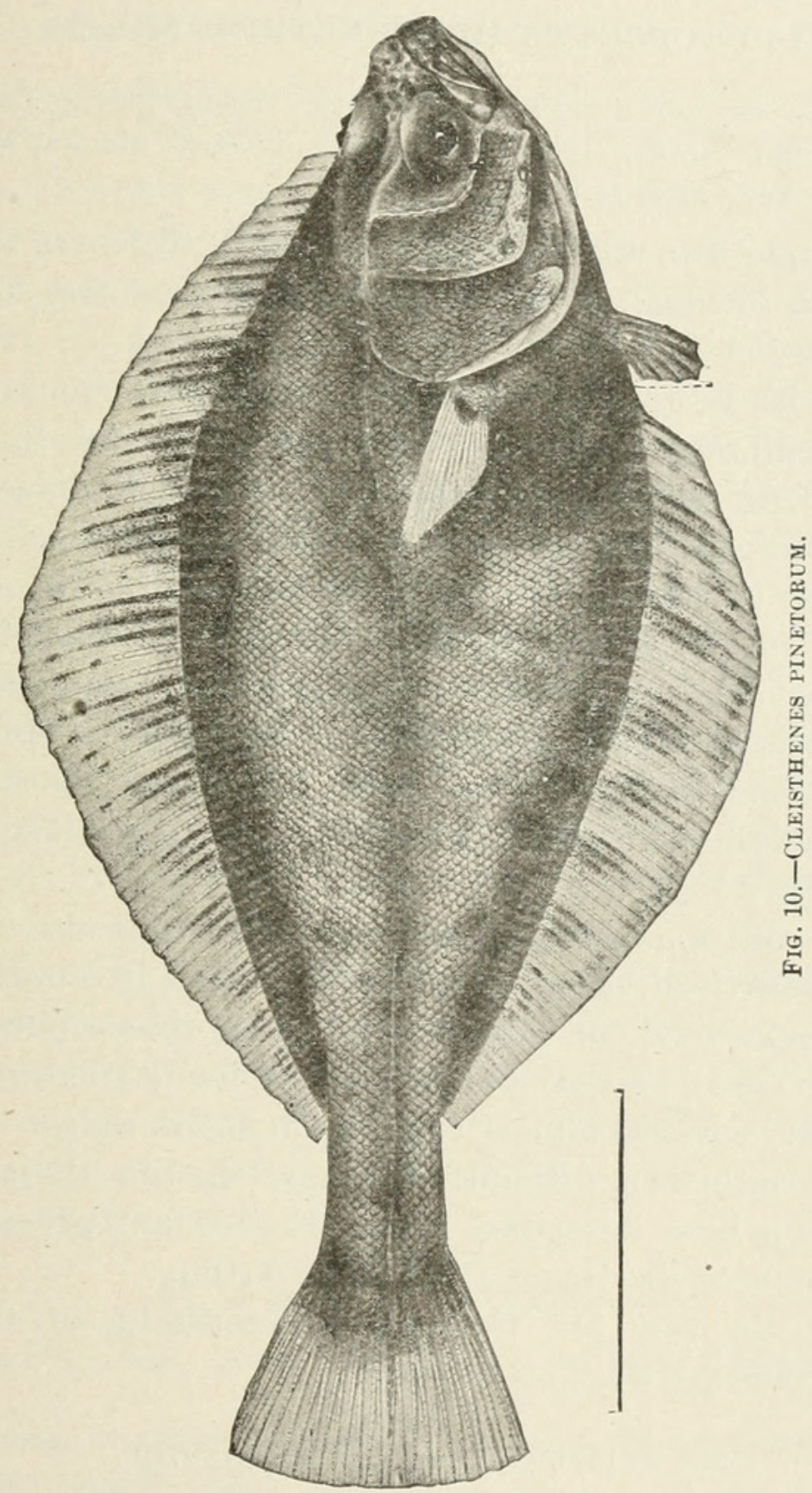

Cat. No. 51403, U.S.N.M.; cotypes are No. 8391, Stanford University.

(pinetorum, of the pines; in reference to Matsushima Bay: matsu, pine; shima, island.)

12. PROTOPSETTA Schmidt.

Protopsetta Sснмidт, Pisc. Mar. Orient, 1904, p. 230 (herzensteini).

This genus is allied to Hippoglossoides, differing in the insertion of the upper eye, which is placed on the upper outline of the head, as in 
Atheresthes and Reinhardtius. The dorsal begins over the posterior part of the eye, and the teeth are rather small and close together.

The fin rays are in relatively small numbers(D. 74, A. 54), and the vertebræ also $(11+29)$, characters which separate this genus from Reinhardtius. The caudal fin is truncate and not lunate. Okhotsk Sea. ( $\pi \rho \tilde{\imath} \tau o s$, first; $\psi \tilde{\eta} \tau \tau \alpha$, flounder.)

\section{PROTOPSETTA HERZENSTEINI (Schmidt).}

Hippoglossoides herzensteini Sснмпт, Pisc. Mar. Orient, 1904, p. 229 (Broughton Bay, Gensan, Korea, Bay of Paris at Vladivostok, Mauka, North Coast of Saghalin, Lake Khalizan).

\section{Habitat. - Japan Sea and Okhotsk Sea, south to Korea.}

Dorsal, 70 to 75 ; anal, 53 to 56 ; pectoral, 11 ; ventral, 6 ; scales, 82 tc 84 ; vertebræ, $11+29=40$.

Upper eye with its range vertical and a little posterior to lower eye. Teeth very small, sharp, and recurved; in two rows on lower jaw. Head covered with scales covered by skin and armed above with sharp bony papillæ; interorbital space rough and almost equal in width to short diameter of lower eye; front nostrils ending in short tubes; gillrakers, $7+16$, the longest equal to the vertical diameter of lower eye; body of eyed side covered with ctenoid scales. Some of the scales, especially anteriorly, have in addition to the marginal spinules rough bony papillæ on their surface; lateral line nearly straight and unbranched; height of caudal peduncle equal to its length; no anal spine; vertebræ, $11+29$.

Origin of dorsal somewhat on blind side and opposite beginning of the posterior fourth of upper eye; first ray equal in length to half the diameter of upper eye, the longest rays equal to combined length of snout and eye; rays of dorsal and anal covered with small rough plates; caudal truncate; covered almost to tip with small scales.

Color, uniform brown without markings; the fins all dark.

This species is here described from the account given by Doctor Schmidt. We have specimens from Port Arthur.

(Named for the late Dr. Solomon Herzenstein, of the Imperial Academy of Sciences, St. Petersburg.)

\section{HIPPOGLOSSUS Cuvier.}

Hippoglossus Cuvier, Règne Animal, 1st ed., II, 1817, p. 221 (hippoglossus).

Eyes and color on the right side. Form oblong, not strongly compressed. Mouth wide, oblique; teeth in the upper jaw in 2 series, those below in 1; anterior teeth in upper jaw, and lateral teeth in lower, strong; no teeth on vomer or palatines; lower pharyngeal teeth in 2 rows. Dorsal fin beginning above the eye, its middle rays elevated, the posterior rays of dorsal and anal bifid; caudal fin lunate; ventral fins both lateral. Scales very small, cycloid; lateral line with 
a strong curve in front. Gillrakers few, short, compressed, wide set. Vertebræ, $16+34$. Largest of the flounders. This genus contains the well-known halibut; abundant on both coasts of the North Atlantic and of the North Pacific.

(hippoglossus, the ancient name of the halibut from i $\pi \pi \circ$, horse; $\gamma \lambda \tilde{\jmath} \sigma \sigma \alpha$, tongue.)

\section{HIPPOGLOSSUS STENOLEPIS Schmidt.}

Hippoglossus stenolepis Sснмпт, Faune Mer. Och. Jap., 1903, p. 19 (Okhotsk Sea, name only); Pisc. Mar. Orient, 1904, p. 224 (Gulf of Aneva).

Habitat.-Okhotsk Sea, probably south to Hokkaido.

Head, 4.5 in length; depth, 3.3; eye, 8.2 in head, 2 in snout; mandible, 2.8 in head; least depth of caudal peduncle, 4.6 in depth of body; dorsal, 95; anal, 74; pectoral, 17; caudal, 16; branchiostegals, 6.

General shape of body as in Hippoglossus hippoglossus, the head more blunt and convex; eyes equal in size, on right side, and separated by a space $1 \frac{1}{3}$ times the length of the upper eye; teeth large, in two rows on upper jaw, in a single row on sides of lower jaw and in double row in front; scales everywhere cycloid and covered by skin; at the posterior end of some of them a rough bony plate, which is easily detached; no supplementary scales.

Origin of dorsal opposite front of pupil, its greatest height one-third of depth of body; length of pectoral equal to postorbital part of head; caudal somewhat concave; ventral reaching beyond front of anal.

Color, olive brown with bright spots corresponding to the bony plates.

This species differs from $H$. hippoglossus in the construction of its scales and in having a smaller number of fin rays and gillrakers. Length of specimen described, 1047 millimeters. (Schmidt.)

It is known to us solely from Schmidt's account. It seems to replace the common halibut in the Sea of Okhotsk.

( $\sigma \tau \varepsilon v o ́ s$, narrow; $\lambda \varepsilon \pi i s$, scale).

\section{REINHARDTIUS Gill.}

Reinhardtius Gill, Cat. Fishes, East Coast N. A., 1861, p. 50 (hippoglossoides; no description).

Platysomatichthys Bleek ER, Comptes Rendus, Ac. Sci. Amsterdam, XIII, 1862, p. 426 ( pinguis=hippoglossoides).

Reinhardtius Gul, Proc. Ac. Nat. Sci. Phila., 1864, p. 218 (hippoglossoides).

Eyes and color on right side. Body more or less elongate, compressed; head long and large; mouth large; maxillary reaching beyond eye; jaws with strong, unequal teeth, the upper with 2 series in front, these converging behind; lower jaw with a single series of strong, distant teeth; no teeth on vomer or palatines. Gillrakers few, short, stout, and rough. Fins rather low; caudal fin lunate. Lower pharyngeal teeth in one row. Scales small, cycloid; lateral line without 
anterior curve. Fin rays and vertebræ numerous, as in the halibut. Two species known, arctic fishes, in some degree intermediate between the true halibut and Atheresthes.

(Named for Prof. Johann Reinhardt, of the University of Copenhagen, an able investigator of the fishes of Greenland).

24. REINHARDTIUS MATSUUR $Æ$ Jordan and Snyder.

Hippoglossus grœnlandicus Ishiкawa and Matsu'üra, Prel. Cat., 1897, p. 25 (Sagami Bay). (Not of Authors.)

Reinhardtius matsurix Jordan and SNyder, Journ. Coll. Sci. Imp. Univ., XV, 1901, p. 309, pl. xvi, figs. 7, 8 (Sagami Bay).

Habitat.-Sagami Bay, probably in deep water.



Body dextral; interorbital width 3 in maxillary; a little less than longitudinal diameter of lower eye; cleft of mouth same on both sides; lateral line single, not sharply curved anywhere, running obliquely downward to a point a little above middle of body and posterior to base of pectoral a distance equal to 2 times length of maxillary, then straight backward to end of caudal fin, similar on blind side; dorsal fin inserted just behind eye; anal inserted below 26th dorsal ray; dorsal and anal extending an equal distance posteriorly; length of caudal peduncle $2 \frac{1}{2}$ times in head; minute scales on interradial membrane of both dorsal and anal; length of pectoral equal to maxillary.

Color plain brown.

A stuffed specimen about $1 \frac{1}{4}$ feet long, No. 456, Imperial Museum, Tokyo. Locality Misaki. This species is allied to Reinhardtius hippoglossoides, the Greenland Halibut, differing in the larger scales and in other characters. No second specimen is known.

(Named for Mr. K. Matsuura, curator of fishes in the Imperial University Museum at Tokyo.)

\section{ATHERESTHES Jordan and Gilbert.}

Atheresthes Jordan and Gilbert, Proc. U. S. Nat. Mus., 1880, p. 51 (stomias).

Eyes and color on the right side. Body very long and slender, closely compressed, tapering into a long and slender caudal peduncle; head elongate, narrow; mouth extremely large, oblique; the long and narrow maxillary extending beyond the eye; each jaw with 2 irregular series of sharp, unequal, arrow-shaped teeth, some of them long and wide set, and others short and close set, sharp; the long teeth freely depressible. Gill rakers numerous, long, slender, and stiff, strongly dentate within. Scales rather large, thin and readily deciduous, slightly ciliated, those on the blind side similar, smooth; lateral line without arch. Fins low and fragile; dorsal beginning over the eye, its anterior rays low, the posterior rays somewhat forked; no anal spine; pectorals and ventrals small, both of the latter lateral; vaudal lunate. 
No.1484. JAPANESE FLOUNDERS AND SOLES-JORDAN \& STARKS.

A genus of subarctic flounders, doubtless degenerate, rather than primitive in its traits.

( $\alpha \dot{\prime} \theta \dot{\eta} \rho$, the beard or spike of an ear of corn; $\varepsilon^{\prime} \sigma \imath^{i} \omega$, , to eat; from the arrow-shaped teeth.)

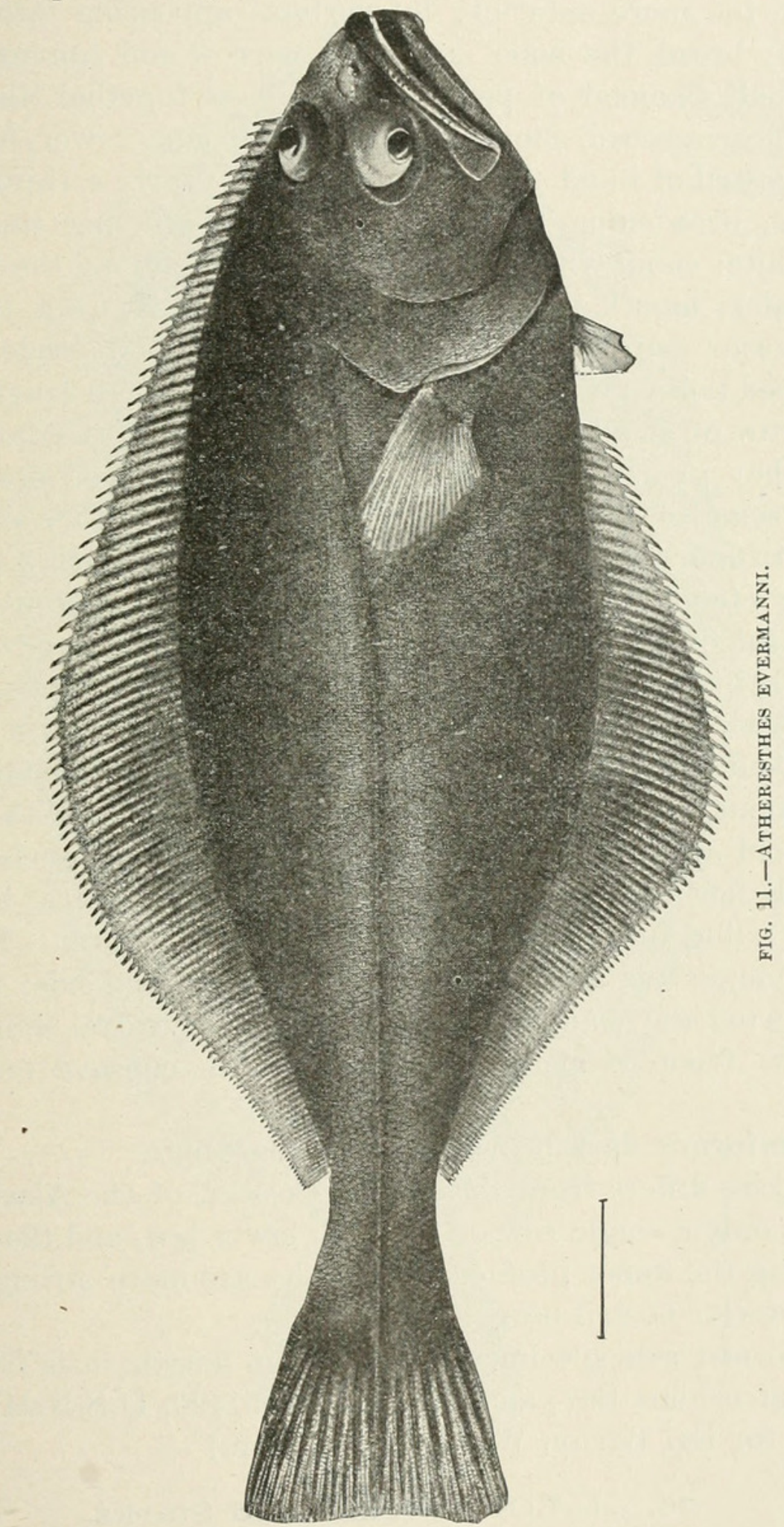

25. ATHERESTHES EVERMANNI Jordan and Starks.

Atheresthes evermanni JoRdan and Starks, Bull. U. S. Fish Commission, XXII, 1902 (1904), p. 630, pl. v, fig. 1 (Matsushima Bay).

Habitat.-Matsushima Bay, in deep water.

Head, 3.3 in length; depth, 3; D. 114; A. 94; scales, 109; upper 
eye, 4.75 in head; snout from upper eye, 4; maxillary, 1.9; pectoral of eyed side, 2.1 ; of blind side, 3.25 ; upper lobe of caudal, 1.75.

Profile of snout on same curve with that behind eye; very slightly depressed above eye; eyes scarcely reaching to upper profile, the lower one the more anterior; interorbital appearing rather flat and moderately broad, the bone, however, narrow and convex, its width less than half diameter of pupil; nostrils close together, the posterior of eyed side in a broad, short tube, anterior in a narrower, longer tube; anterior nostril of blind side with a long flap nearly a third as long as upper eye, broadening toward its tip and becoming conspicuously opaque white; snout with many pores scattered among the irregularly placed scales; mouth reaching to or very slightly past the vertical from posterior margin of lower eye; teeth long and slender and with lance-shaped points, in a single row on lower jaw, their length unequal; a double row of smaller teeth on side of upper jaw, the outer row the smaller; they grow larger anteriorly, become curved inward, fanglike and some of them depressible; gill rakers rather slender, the longest a trifle less than half length of eye, their number $3+10$; scales very finely ctenoid, the spinules short, fine, and numerous, only seen upon careful examination with a lens; many scales have only a few irregular spinules; others are entirely without them, appearing as if they had been rubbed off; head and body everywhere with numerous, small, cycloid supplementary scales crowded in; scales of blind side all cycloid; snout, mandible, maxillary, and interorbital with numerous small cycloid scales, those on latter extending out on eyeball to edge of iris; all fins rather closely covered with fine scales; lateral line slightly bending upward from opposite tip of pectoral. Pectoral of eyed side longer and more pointed than that of blind side; first ray of dorsal inserted above anterior margin of pupil; ventral short, scarcely reaching to front of anal. Caudal shallowly concave on posterior outline.

Color uniformly dark brown, without markings.

This species differs from Atheresthes stomias, of the Alaskan fauna, in having only a single row of teeth on lower jaw, and the upper eye not reaching the upper profile. The scales are more strongly ctenoid and the anterior nostril bears a long flap.

The type and sole specimen is $270 \mathrm{~cm}$. in length; it is from station 3772 in Matsushima Bay, and is numbered 51490, U.S.N.M.

(Named for Dr. Barton Warren Evermann.)

\section{ALAEOPS Jordan and Starks.}

Alrops Jordan and Starks, Bull. U. S. Fish Com., XXII, 1902 (1904), p. 623 (plinthus).

This genus is allied to Precilopsetta. Body covered with large ctenoid scales which are somewhat caducous; eyes and color on the right 
side; lateral line simple, with a broad flat-topped arch in front; mouth moderate; teeth small in bands; gillrakers short and sharp.

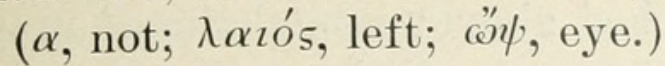

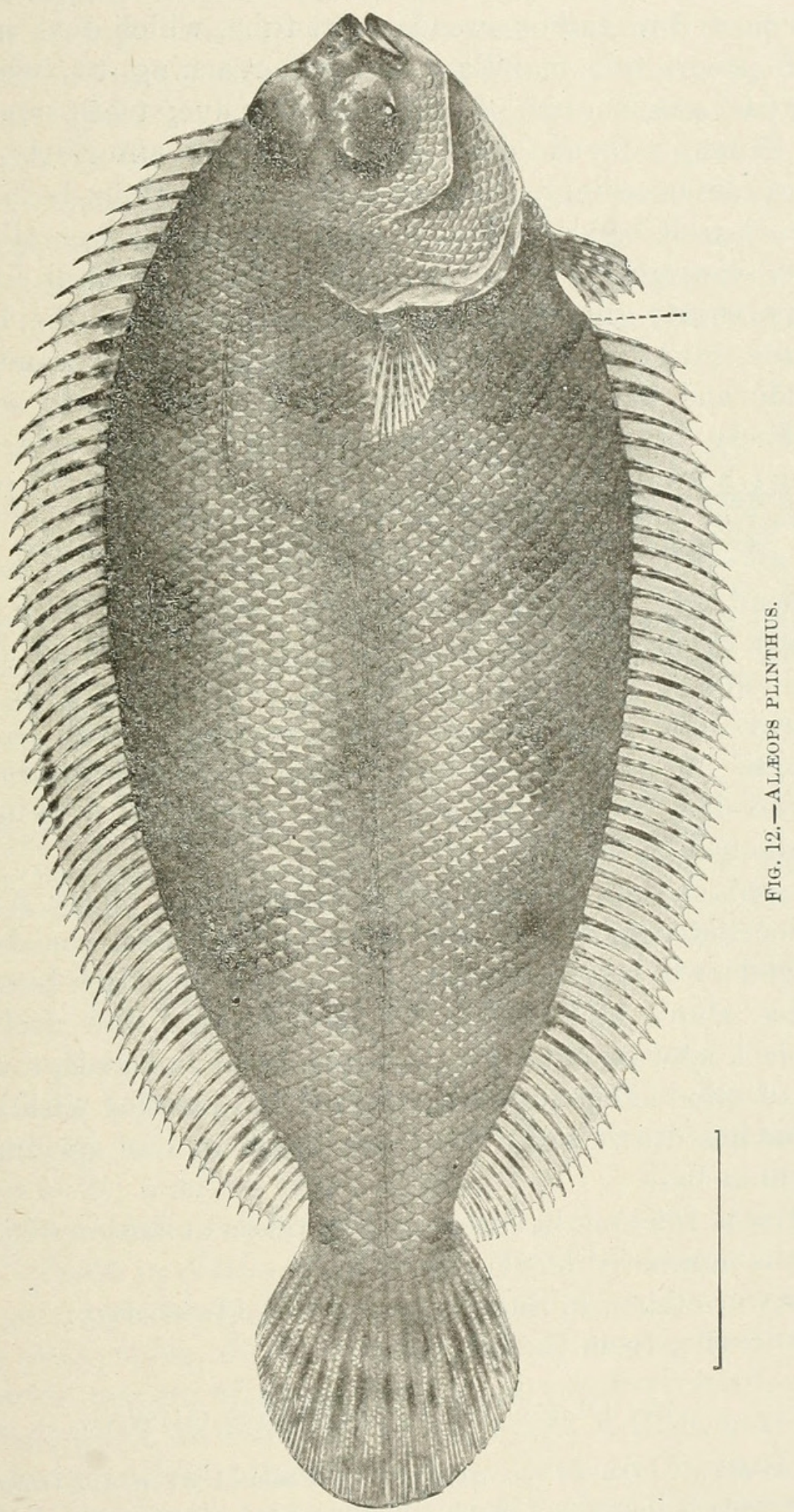

26. ALAOPS PLINTHUS Jordan and Starks.

Alæops plinthus Jordan and Starks, Bull. U.S. Fish Com., XXII, 1902 (1904), p. 623 , pl. v, fig. 2 (Suruga Bay, Owari Bay).

Habitat.- Southeast coast of Japan, in deep water.

Head, 4 in length; depth, 2.4; D. 61; A. 53; scales, 65 (pores); 
upper eye, 3 in head; snout from upper eye, 4.16; maxillary, 3.16; pectoral of eyed side, 2.25; ventral median; caudal rays, 1.

Anterior body outline strongly arched above; orbital rim of upper eye protruding beyond rest of profile; snout a little produced, blunt; anterior nostril in rather broad, short tube, which does not reach to edge of preorbital; maxillary curved, reaching to below or very slightly past anterior rim of pupil of lower eye; teeth small, in a very narrow band on eyed side, growing wider anteriorly, somewhat smaller on premaxillary. On blind side the teeth on both jaws are in moderately wide bands. Eyes equal in size, the lower slightly more anterior, separated by a narrow naked ridge; vertical limb of premaxillary short; gillrakers short and rather sharp, the longest onehalf to one-third diameter of pupil, $5+10$ in number: caudal peduncle very wide and flat, its length one-third of its width; scales large, rather finely but very evidently ctenoid on eyed side, cycloid on blind side; head on eyed side, anterior to posterior rim of pupil above, and posterior end of mandible below, without scales; lateral line turning abruptly upward at a sharp angle two-thirds the head's length behind head, and forming a conspicuous flat-topped arch, as high as half length of head; dorsal beginning slightly on blind side, a little behind middle of eye, length of first ray contained 1.1 in upper eye, longest rays near posterior end of fin, the longest 2.25 in head; pectorals equal in size; caudal broad and pointed behind; no lateral angles, the sides broadly rounded from tips of the long median rays to lateral edges of fin base.

Color pinkish slaty-brown, usually mottled with black; 2 inconspicuous semiocellated spots, one near dorsal and one near anal base a head's length anterior to base of caudal; less conspicuous dark irregular spots along side above anal and below dorsal, one below arch of lateral line; a black spot on outer rays of caudal; all fins except ventral and pectoral of blind side irregularly spotted and mottled with black. The membrane has drawn away from the scales in our specimen leaving them light at base.

The type is $155 \mathrm{~mm}$. in entire length, taken at station 3708 in Suruga Bay. It is numbered 51406 , U. S. N. M.

Others were taken in Suruga Bay and in Owari Bay. ( $\pi$ 入iv $\theta$ os, tile, from the color.)

\section{PLEURONICHTHYS Girard.}

Pleuronichthys GIrard, Proc. Ac. Nat. Sci. Phila., 1854, p. 139 (cœenosus).

Heteroprosopon Bleeker, Comptes Rendus Acad. Amsterdam, XIII, 1862, p. 8 (cornutus).

Parophrys Günther, Cat. Fishes, IV, 1862, p. 454; not of Girard.

Eyes and color on the right side. Body deep; head short, with very short, blunt snout; mouth small, with several series of slender, acute 
teeth, which are most developed on the blind side, and are often wanting in one or both jaws on the colored side; no teeth on vomer or palatines; lips thick, with several lengthwise folds within which is a series of short fringes. Lower pharyngeals narrow, each with a double row of very small teeth. Gillrakers wide set, very short and weak. Lateral line nearly straight, with a dorsal branch in our species. Scales small, cycloid, nonimbricate, embedded. Dorsal fin anteriorly twisted from the dorsal ridge toward the blind side; anal fin preceded by a spine; caudal fin convex behind. Intestinal canal elongate. Herbivorous species, feeding chiefly on algæ. Pacific Ocean.

The species of Pleuronichthys spawn in the spring and live in comparatively deep water. The protruding eyes are both turned to the right side very early in specimens $\frac{1}{3}$ inch long.



27. PLEURONICHTHYS CORNUTUS (Schlegel).

BIKIKAREI (FROG-FLOUNDER); MOCHIGAREI (RICE-CAKE-FLOUNDER);

MITIGAREI (BOARD-FLOUNDER); OMIGAREI (FLOUNDER OF OMI).

Platissa cornuta Schlegel, Fauna Japonica, Poiss., 1846, p. 179, pl. xc, fig. 1 (Nagasaki).-Bleeker, Verh. Bat. Gen., XXVI, Japan, p. 121.

Heteroprosopon cornutus BleEker, Compt. Rend. Ac. Sci. Amst., 1862, Pleuron., p. 8 (Nagasaki).

Parophrys cormuta GÜNTher, Cat. Fish, IV, 1862, p. 455 (copied); Shore Fishes, Challenger, 1880 , p. 70 (Kobe).-Namiye, Class. Cat., 1881, p. 110 (Tokyo).--Ishikawa and Matsu'üra, Prel. Cat., 1897, p. 24 (Yeshigo).Отакі, Journ. Bur. Fish, 1897, p. 7, pl. viII, p. 90 (Japan).

Pleuronichthys cornutus Steindachner, Reise Aurora, 1896, p. 217 (Kobe).Jordan and Evermann, Fish. North Mid. Amer., III, 1898, p. 2637 (Japan).Jordan and Snyder, Proc. U. S. Nat. Mus., XXIII, 1901, p. 769 (Yokohama); p. 900 (Hakodate, Tokyo).-Jordan and Starks, Bull. U. S. Fish Comm., XXII, 1902 (1904), p. 923 (Suruga Bay).

Habitat. - Entire coast of Japan, north to Hakodate.

Head, from 4 to $4 \frac{2}{5}$ in length without caudal; depth, $1 \frac{2}{3}$ to $1 \frac{4}{5}$. Upper eye, $3 \frac{1}{2}$ to 4 in head; snout to upper eye, 5; maxillary, $4 \frac{1}{2}$. Dorsal, 70 to 76 ; anal, 52 to 54 . Scales, 80 .

Mouth very small; the maxillary reaching to below anterior margin of pupil. Teeth in villiform bands, mostly on the blind side of mouth. Eyes large; opposite each other; separated by a sharp, naked ridge. A strong sharp spine, directed backward, on interorbital ridge opposite posterior margin of eyes; another, directed outward, and curved slightly backward, on anterior part of ridge, a little behind front of eyes; a short-pointed tubercle of bone directed forward at tip of snout; and a similar one directed outward in front of each eye. Gillrakers scarcely developed; 4 or 5 small tubercles on lower part of arch.

Scales small and embedded; not imbricated anteriorly. Origin of dorsal on blind side at a point a little above the level of front of premaxillary, and opposite middle of upper eye. Longest dorsal rays equal to those of anal and contained $1 \frac{1}{3}$ in head. Pectorals bluntly 
pointed; that of eyed side $1 \frac{3}{5}$ to $1 \frac{3}{4}$ in head; that of blind side twothirds as long as its mate and contained $2 \frac{1}{3}$ in head. Ventral of blind side placed more anteriorly and farther from the ventral ridge of body than its mate. Caudal rounded.

Color rather light gray, everywhere spotted with irregular, or more or less round spots of dark brown. These are sometimes very small and scattered, sometimes lighter in the center, or arranged in irregular rings, or sometimes large and narrowly separated. The edges of the vertical fins are dusky or dark brown on the blind side. A few specimens were colored and spotted on both sides and in these cases the front of the dorsal is usually not on the blind side, but is on a free lobe which overhangs the head; the upper eye is more on the dorsal outline of the head than in normal examples; the ventrals are usually more symmetrical; and the pectorals are both of the same length, these characters possibly indicating that the fish may swim on either side.

We have numerous specimens from Kobe, Aomori, Hiroshima, Nagasaki, Hakodate, Onomichi, Wakanoura, Tsuruga, Tokyo, and Misaki. This species is one of the commonest of the small flounders of Japan.

(cornutus, horned.)

\section{LEPIDOPSETTA Gill.}

Lepidopsetta Gill, Proc. Ac. Nat. Sci. Phila., 1864, p. 195 (umbrosus).

Body robust; mouth small. Teeth stout, conical, little compressed,

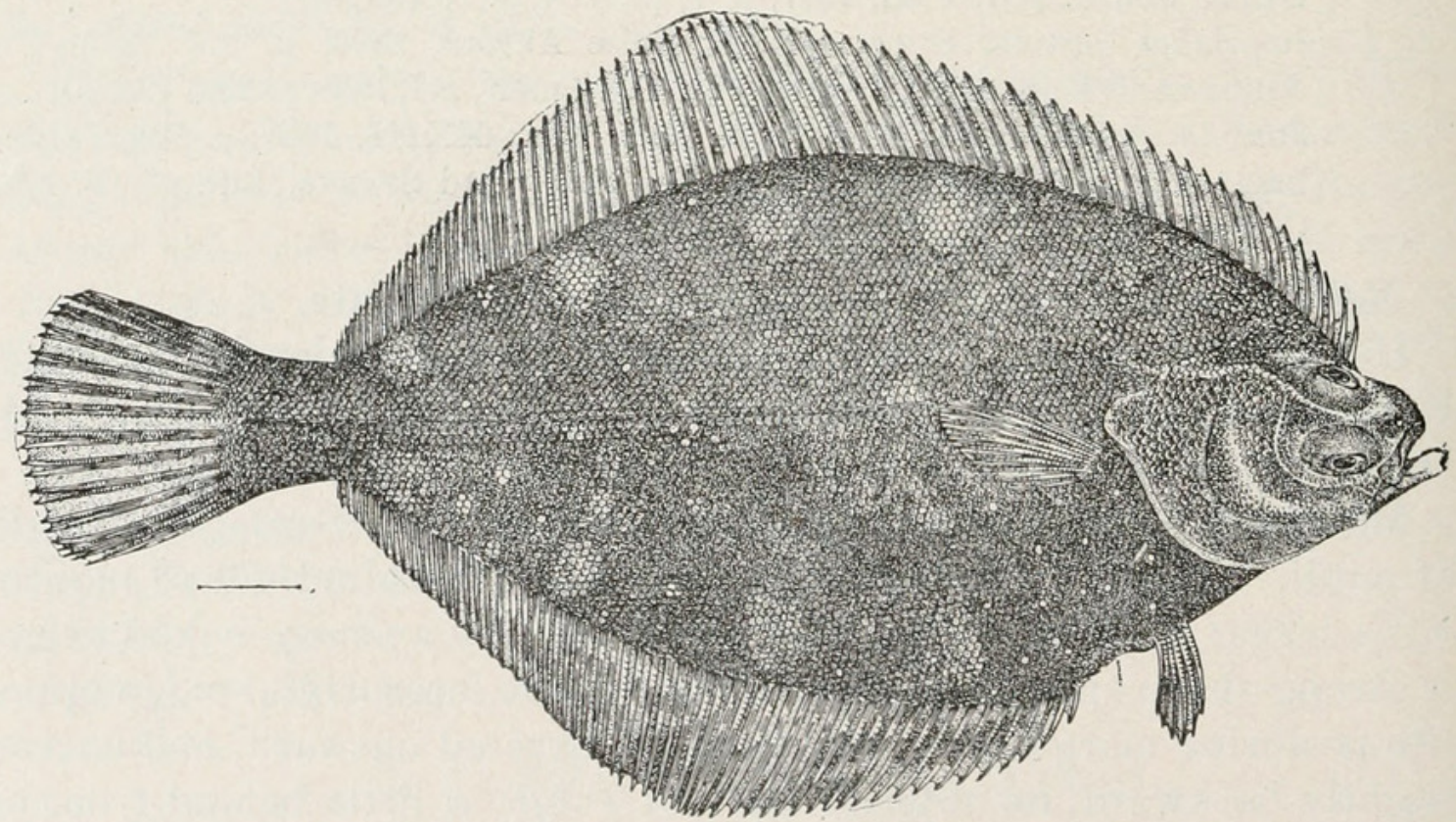

Fig. 13.-LePidopsetta BILINEATA.

bluntish, in one series, rather irregularly placed. Lateral line with a distinct arch in front and accessory dorsal branch; scales imbricated, rough ctenoid, smooth in the very young. A single species, abundant on the Pacific coasts. It is close to Limanda, from which the accessory branch of the lateral line alone separates it.

( $\lambda \varepsilon \pi i s$, scale; $\psi \tilde{\eta} \tau \tau \alpha$, flounder.) 


\section{LEPIDOPSETTA BILINEATA (Ayres).}

Platessa bilineata Ayres, Proc. Ac. Nat. Sci. Cal., 1855, p. 40 (San Francisco).

Platichthys umbrosus GIrard, Proc. Ac. Nat. Sci. Phila., 1856, p. 136 (Puget Sound).

Pleuronectes perarcuatus Cope, Proc. Ac. Nat. Sci. Phila., 1873, p. 30 (Unalaska). Pleuronectes umbrosus Günther, Cat., IV, 1862, p. 454.

Pleuronectes bilineatus Günther, Cat., IV, 1862, p. 444.-Jordan and Gilberer, Synopsis, p. 833, 1883.

Lepidopsetta bilineata Gill, Proc. Ac. Nat. Sci. Phila., 1864, p. 195.-Lockington, Proc. U. S. Nat. Mus., 1879, p. 103; Rep. Com. Fisheries, California, 1878-79, p. 46.-Jordan and Gilbert, Proc. U. S. Nat. Mus., 1880, p. 453; Proc. U. S. Nat. Mus., 1881, p. 68.-Bean, Proc. U. S. Nat. Mus., 1881, p. 241; Cat. Coll. Fish. U. S. Nat. Mus., 1883, p. 19; Proc. U. S. Nat. Mus., 1883, p. 353.-JorDAN, Nat. Hist. Aquat. Anim., 1884, p. 184, pl. L.-Jordan and Goss, Review Flounders and Soles, 1889, p. 286.-Jordan and Evermann, Bull. Fish North. Mid. Amer., III, 1898, p. 2643, pl. ccclx xvi, fig. 928 (Alaska, etc.).-SснмпDт, Poiss. Mar. Orient, 1904, p. 232 (Bay of Shogun, Shendagen, Japan, Mauka, Gensan, Atka).

\section{Habitat.-Bering Sea, south to Monterey and to Korea.}

Head, $3 \frac{3}{5}$; depth, $2 \frac{1}{8}$. D. 80 ; A. 60 ; teeth, $\frac{27+7}{25+10}$; scales 85 . Vertebræ $11+29=40$. Body, broadly ovate, thickish; mouth moderate, turned toward the left side; teeth stout, conical little compressed, bluntish, in one series, rather irregularly placed. Lower pharyngeals broad, with two rows of blunt teeth. Gillrakers few, very short, thick and weak, without teeth. Snout projecting; eyes large, separated by a prominent ridge, which, like the cheeks and upper portion of opercle, is covered with rough stellate scales; lower eye advanced; opercle, subopercle, and interopercle of left side scaly; preopercle naked. Scales rather small, mostly ctenoid, not closely imbricated, those on the blind side smooth; scales on cheeks and other parts of head very rough; scales of body smoother and less closely imbricated anteriorly, the degree of roughness variable, northern specimens (var. umbrosus) being roughest. Lateral line moderately arched anteriorly, with an accessory dorsal branch, which is less than one-half length of head; height of arch less than one-third its length. Dorsal beginning over eye, its anterior rays low; caudal convex; anal preceded by a spine; a concealed spine behind ventrals; rays of dorsal and anal all simple; dorsal and anal somewhat scaly; caudal three fifths length of head; pectoral one-half head. Lower pharyngeals broad, each with two rows of blunt teeth. Yellowish brown, with numerous round, pale blotches. Pacific coast of America and Northern Asia, Bering Strait to Monterey and to Sakhalin. This species is one of the commonest of the flounders of the Pacific coast, its abundance apparently increasing toward the northward. In Bering Sea it far outnumbers all other flounders. Schmidt records it from the Sea of Ochotsk and the Sea of Japan. 


\section{LIMA NDA Gottsche.}

Limanda Gotтsche, Archiv für Naturgsch., 1835, p. 100 (limanda). Myzopsetta Gill, Proc. Ac. Nat. Sci. Phila., 1864, p. 217 (ferruginea).

Limandella Jordan and Starks, new subgenus (yokohamæ).

Teeth uniserial; lateral line with a distinct arch in front, and without accessory dorsal branch; scales more or less imbricated, rough ctenoid in the typical species but cycloid in one of the Japanese species; vertebræ about 40. This genus is closely allied to Pseudopleuronectes, from which it differs only in the presence of an arch on the anterior part of the lateral line.

Color of eyed side brownish; the blind side usually washed with rusty red or with yellow in life.

The genus may be divided into two groups in accordance with the dentition. In Limanda proper, the teeth are bluntish conical not close set, in an irregular row, which extends on the blind side of each jaw. In certain Japanese species (Limandella) the teeth are broad, truncate, evenly set, restricted mainly to the blind side of each jaw.

KEY TO SPECIES.

a. Limanda. - Teeth conical, in an irregular row extending on eyed side of jaws.

b. Dorsal rays about 66 ; anal rays about 50 .

c. Scales about 80 , those of blind side rough; snout not projecting . . . aspera, 29

cc. Scales about 90 , those of blind side smooth; snout produced - proboscidea, 30

bb. Dorsal rays about 60 ; anal about 45 ; scales about 70 ; a rough area behind eye;



aa. Limandella.-Teeth broad, truncate, close-set, confined chiefly to the blind side of each jaw.

d. Dorsal rays, 62 ; anal, 48 ; scales, $75 \ldots \ldots \ldots \ldots \ldots \ldots \ldots \ldots \ldots \ldots \ldots$. . . . . . . . . . . 32 dd. Dorsal rays, 65 to 75 ; anal rays, 50 to 55 ; scales, 75 to 80 .

e. Head with the snout slender and produced .......................

ee. Head with the snout not notably produced . . . . . . . . . . . . . yokohamæ, 34

\section{LIMANDA ASPERA (Pallas).}

Pleuronectes asper Pallas, Zoogr. Rosso-Asiat., III, 1811, p. 425 (east coast of Siberia).-Günther, Cat., IV, 1862, p. 454.-Steindachner, Pleuronectiden, ete., aus Decastris Bay, 1870-1875.-Jordan and Gilbert, Synopsis, 1883, p. 835 .

Limanda aspera Bean, Proc. U. S. Nat. Mus., 1881, p. 242, Cat. Coll. Fish, U. S. Nat. Mus., 1883, p. 20; Proc. U. S. Nat. Mus., 1883, p. 354; Hist. Aquat. Anim., 1884, p. 184, pl. x Lvin.-Jordan and Goss, Review Flounders and Soles, 1889, p. 288.-Jordan and Evermann, Fish, North and Middle Amer., III, 1898, p. 2645, pl. ccclxxvir, fig. 930 (Alaska to Saghalin).-Jordan and Gilbert, Rept. Fur Seal Exp., III, p. 491 (Robben Reef, Petropaulski, etc.).-Sснмпрт, Pisc. Mar. Orient, 1904, p. 233 (Mauka, Usta, Gulf of Aniva, Papou).

Habitat.-Bering Sea and Okhotsk Sea.

Head, $3 \frac{1}{2}$; depth, 2. D. 69; A. 53; scales, about 80 . Form of Lepidopsetta bilineata. Teeth small almost conical, on both sides of the mouth; interorbital space narrow, scaly; opercle and preopercle 
naked below; gillrakers very feeble; pharyngeals not very broad, their teeth bluntish, not paved; scales small, wide apart, partly embedded, each one with 1 to 4 spinules, which are almost erect; anterior scales with 3 to 4 of these spinules; posterior mostly with 1 ; scales of blind side smoother; only middle rays of dorsal and anal scaly; no accessory lateral line; anal spine present; twentieth anal ray and thirty-seventh dorsal ray longest; caudal, double truncate. Brown, nearly plain, the blind side with tinges of lemon yellow. Bering Sea, generally common, south to Vancouver Island and to the Okhotsk Sea. We have specimens from Petropaulski and Robben Reef, Bristol Bay, and Herendeen Bay.

(asper, rough.)

\section{LIMANDA PROBOSCIDEA Gilbert.}

Limanda proboscidea Gilbert, Rept. U. S. Fish Com. for 1893 (1896) p. 460, pl. xxxin (Bristol Bay, Herendeen Bay).-Jordan and Gilbert, Rept. Fur Seal Expl., III, 1898, p. 491 (Bristol Bay, Herendeen Bay).-Jordan and Ever-Mann, Fish North and Mid. Amer., III, 1898, p. 2645 (Bristol Bay, Herendeen Bay).—-Sснмгdт, Faune Mer Och. Jap., 1903, p. 19 (Okhotsk Sea) Pisc. Mar Orient, 1904, p. 236 (Mauka, Ustil R., Lutogi, Moloro R. Okhotsk Sea).

\section{Habitat.-Bering Sea, Okhotsk Sea.}

Depth, $2 \frac{1}{4}$ to $2 \frac{1}{2}$ in length; head, large, 3 to $3 \frac{1}{5}$ in length in a specimen 7 inches long. D. 63 to 67 ; A. 47 to 49 ; scales, 86 to 95 . Resembling L. ferruginea, but having fewer rays in dorsal and anal, larger scales and longer snout. Profile sharply angulated above front of upper eye, the snout convexly protruding; form varying from very slender to broadly elliptical, the 2 outlines equally curved; caudal peduncle short, widening backward, its least depth twice its length; mouth oblique, maxillary reaching beyond front of lower eye, 4 in head; teeth narrow, little compressed, in a single series on both sides of the jaw, extending farther back on the blind side; eyes on right side; lower eye well in advance of upper, the diameter of upper eye $5 \frac{1}{2}$ to 6 in head, $1 \frac{1}{2}$ in snout; vertical from front of upper eye, falling midway between front of orbit and front of pupil of lower eye; interorbital space a very narrow, sharp ridge, naked in females, with a single series of ctenoid scales in males; gillrakers short, about equal to diameter of pupil, 13 or 14 in number, 9 or 10 on lower limb; scales loosely imbricated, ctenoid in males on colored side, smooth in females; blind side of both sexes smooth; head scaled on eyed side in males; the opercle, subopercle, interopercle, and preopercle mostly naked in females; head on blind side naked; rays of vertical fins with a single series of ctenoid scales; dorsal fin beginning slightly behind front of upper eye, the first 3 rays usually higher and with membranes more deeply incised than in those which follow; highest portions of both dorsal and anal fins behind the middle of the body; these fins about equal, their longest rays equal to the snout and eye; caudal two-thirds 
head; pectorals short, one-third in head; ventrals reaching beyond front of anal, $3 \frac{1}{3}$ in head; the usual small antrorse spine in front of anal fin. Color light grayish or brownish, thickly covered with small whitish spots; entire left side with margins of dorsal, caudal, and anal fins bright lemon yellow (as in Limanda ferruginea); vertical fins grayish, with an occasional dark-brown ray. Specimens described $7 \frac{1}{2}$ inches long. Bering Sea, Bristol Bay, Herendeen Bay.

(proboscideus, having a long snout or proboscis.)

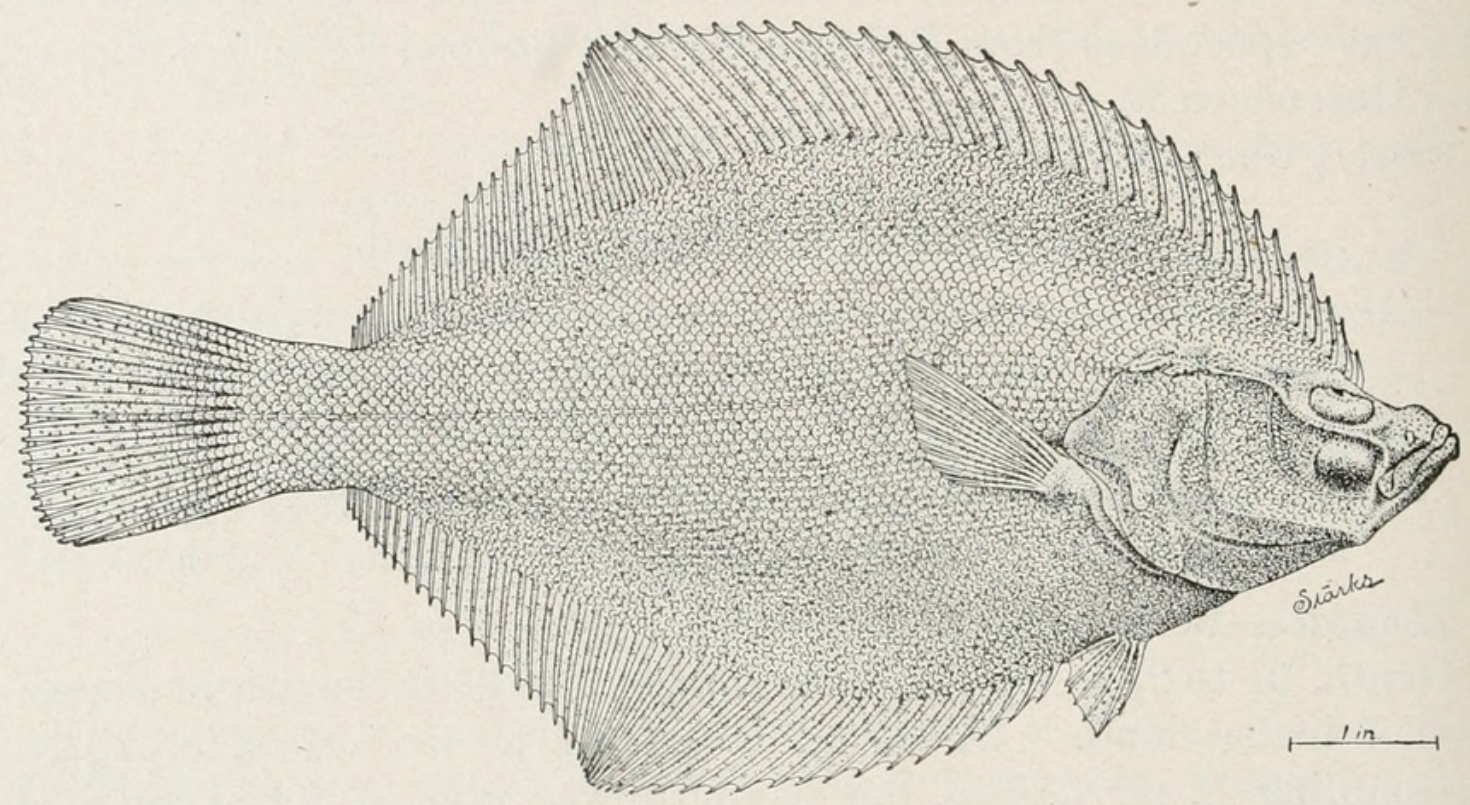

Fig. 14.-LIMANDA IRIDORUM.

31. LIMANDA IRIDORUM Jordan and Starks, new species.

Habitat. - Seas of Hokkaido.

Head, 3 to $3 \frac{1}{4}$ in length to base of caudal; depth, $1 \frac{7}{8}$ to $2 \frac{1}{8}$. Eye, $6 \frac{1}{2}$ in head; maxillary, 4 to $4 \frac{1}{4}$; snout, $4 \frac{1}{2}$ to 5 . Dorsal, 57 to 63 ; anal, 44 to 46 . Pores of lateral line, 66 to 72 .

Upper outline of head very concave; the snout produced and turned upward; the backward extending processes from the premaxillaries forming a prominent projection on the upper edge of the snout. A vertical line drawn upward from the posterior edge of the lower eye cuts through the beginning of the posterior fourth of the upper eye. Interorbital space a very high, sharp, naked ridge; smooth between eyes, but becoming rough directly behind them and passing into a rather broad rugose area running above opercles to beginning of lateral line. A similar rough area following ridge of preopercle. A rough ridge, rather high anteriorly, running from snout to beginning of lateral line on blind side of head. Mouth rather large and oblique; the maxillary reaching to edge of lower orbital cavity. Mandible oblique and rather straight; its posterior end forming a prominent angle on ventral outline; its tip projecting beyond snout. Teeth rather sharp and irregular, in an uneven row on both sides of jaws, 
but extending farther around on blind side. Gillrakers pointed, the longest equal to half the diameter of lower eye; 11 developed on lower limb of arch.

Scales everywhere cycloid, embedded anteriorly and not imbricate, posteriorly they are slightly imbricate and not embedded. Height of lateral line curve equal to long diameter of upper eye; length of curve equal to half the length of head.

Pectoral rather pointed, reaching past curve of lateral line; its length equal to half length of head. Origin of dorsal slightly on blind side, opposite front of upper eye. Ventral of blind side a little anterior to that of eyed side. Caudal slightly rounded and angulated at tips of outer rays.

Slate color, finely speckled, and spotted all over by small, brown, irregular marks; these especially conspicuous on the fins.

This species somewhat resembles L. proboscidea, but may be at once known by its larger cycloid scales.

It is represented by six specimens from Mororan, Aomori, and Hakodate.

The type is from Mororan, and is $25 \mathrm{~cm}$. in length. It is numbered 55644 , U.S.N.M.

A cotype is No. 9824, Stanford University.

(iridorum of the iris; from Mororan, which means Iris-huts).

\section{LIMANDA SCHRENCKI Schmidt.}

Limanda schrencki Sснмпрт, Faune Mer. Okhotsk, Japan, 1903, p. 19 (Japan Sea, Okhotsk Sea), (name only); Pisc. Mar. Orient, 1904, p. 235 (Aneva, Mauka, Saghalin).

\section{Habitat.-Japan Sea.}

Head, 4 to $4 \frac{1}{2}$ in length; depth 2 to $2 \frac{1}{2}$. Eye $5 \frac{7}{10}$ to $6 \frac{9}{10}$ in head. Dorsal 61 to 63 ; anal 47 to 49 ; scales 75 to 78 .

Eyes about equal in size; the lower are slightly the more anterior; interorbital space less than half the length of upper eye. Nostrils ending in tubes, the anterior are the longer. Lips thick and fleshy; upper jaw with 12 to 15 teeth on blind side, none on colored side, except in one specimen, which has 2 ; lower jaw with 15 to 17 on blind side; 2 to 4 on colored side. Two rows of blunt, flat teeth on lower pharyngeals; 12 to 15 in each row. Lateral line rough, with a bony outgrowth. Whole head covered with ctenoid scales, except between eyes and on cheek; nape with large scales.

Color of fins and body dark brown, with yellow spots and 6 to 9 black spots in life; often a black spot at tip of blind side of caudal. Japan Sea (Schmidt). Not seen by us.

This species is nearest to L. yokohamæ, but has fewer fin rays; the eyes are smaller than in other species.

(a personal name.)

Proc. N. M. vol. $x \times x i-06-14$ 
33. LIMANDA ANGUSTIROSTRIS Kitahara, new species.

Habitat.- Shores of Hokkaido.

Head, $2 \frac{4}{5}$ to $4 \frac{1}{6}$ in length to base of caudal; depth, $2 \frac{1}{4}$. Upper eye, 5 to $5 \frac{1}{2}$ in head; snout, $5 \frac{1}{4}$ to $5 \frac{1}{2}$; maxillary, $4 \frac{1}{3}$ to $4 \frac{1}{2}$. Dorsal, 68 to 74 ; anal, 52 to 55 . Pores in lateral line, 74 to 78 .

Head rather slender, the snout produced, forming a conspicuously concavity in outline above upper eye. Upper eye a little posterior to lower. Interorbital space, a high, sharp, naked ridge. Maxillary reaching to anterior edge of lower eye, a little past front of orbital cavity. Twenty-two to 24 teeth on blind side of lower jaw, 5 or 6 on the other side; 19 to 22 on blind side of upper jaw, none on the other. Gillrakers short, flat, and pointed, 6 on lower limb of arch.

Dorsal beginning above middle of upper eye or sometimes a little in front of middle. Pectoral pointed; its length $1 \frac{3}{4}$ to $1 \frac{4}{5}$ in head; its

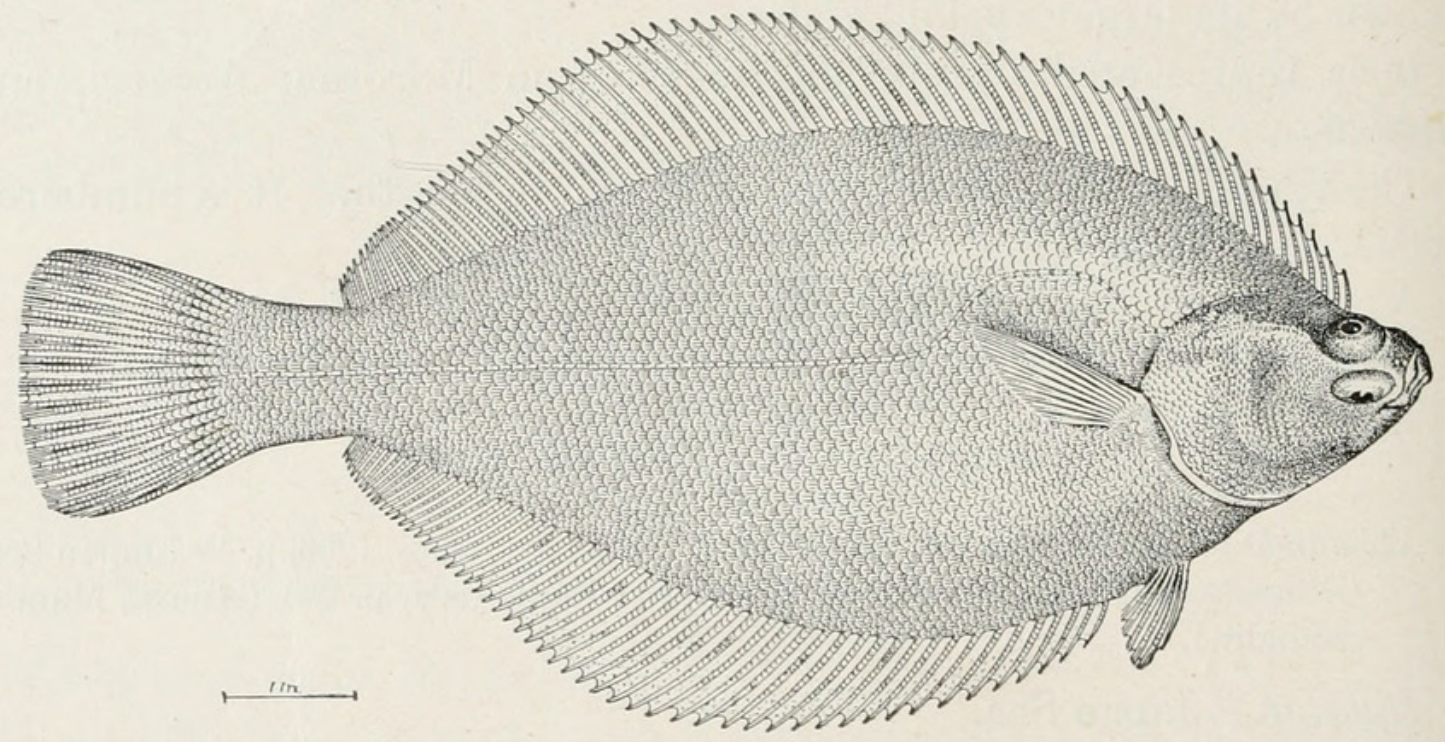

Fig. 15.-Limanda angustirostris.

tip reaching to, or a little past, angle of lateral line. Caudal very slightly convex, angulated at tips of outer rays.

Scales large, embedded, and not imbricated; 13 to 15 scales between middle of lateral line curve and back; 21 to 24 between angle of lateral line and anal. In L. yokohamx there are from 22 to 25 scales in the same place on back, and from 30 to 36 on lower part of sides. Scales everywhere cycloid except on posterior half of eyed side of body. Height of curve of lateral line equal to length of upper orbital cavity; length of curve contained $1 \frac{1}{3}$ to $1 \frac{1}{2}$ in head.

Color uniform slaty brown, without definite markings. The unpaired fins lighter; no color on blind side.

This species differs from Limanda yokohamæ in having the snout more pointed, the head more slender, the teeth smaller, the interorbital space sharper, higher and naked, the scales farther apart, more embedded, and fewer of them counting transversely. The ridge running from upper eye to lateral line is more rugose. 
We have eight specimens taken at Aomori. The type is $28 \mathrm{~cm}$. in length and is numbered 55645, U.S.N.M. Cotypes are No. 9825, Stanford University.

Mr. T. Kitahara of the Imperial Fisheries Bureau, sends us a manuscript description of this species, from a specimen from Aomori. We adopt the specific name chosen by him in place of the one we had devised.

(angustus, narrow; rostrum, snout.)

\section{LIMANDA YOKOHAMÆ (Günther).}

AKAGAREI (RED-FLOUNDER); AMATE OR YAMATE (FLOUNDER).

Pleuronectes yokohamæ Günther, Shore Fishes Challenger, 1880, p. 69 (Inland Sea of Japan, Yokohama).-Oтакі, Journ. Bur. Fish., 1897, p. 6, pl. vi, fig. 4 .

Limandu yokohamx Jordan and Snyder, Proc. U. S. Nat. Mus., XXIII, p. 379, 1900 (Tokyo, Hakodate); Check List, 1901, p. 121 (Yokohama).

Pleuronectes japonicus Herzenstern, Bull. Ac. Sci. Petersb., 1894, p. 130 (Hakodate, Vladivostok). (Not Pleuronectes japonicus Houttuyn.)

Limanda japonica Scнмıdт, Faune Mer. Jap. Och., 1903, p. 19 (Japan Sea); Pisc. Mar. Orient, 1904, p. 234 (Mayka, Hakodate, Vladivostok).

Limanda herzensteini Jordan and SNyder, Proc. U. S. Nat. Mus., XXIII, p. 746, 1901, after Herzenstein.-Jordan and Starks, Bull. U. S. Fish. Comm., XXII, 1904, p. 623 (Matsushima Bay, scales 84 (88 pores); Tsuruga, Matsushima, Hakodate, Aomori, scales 80 to 85 ).

Habitat.-All shores of Japan, north to Vladivostok, south to Obama.

Head, $4 \frac{1}{5}$ to $4 \frac{2}{5}$ in length to base of caudal; depth, $2 \frac{1}{5}$ to $2 \frac{1}{3}$. Upper eye, $5 \frac{1}{2}$ in head; snout, 6 ; maxillary, 4. Dorsal, 65 to 70 ; anal, 50 to 53. Pores in lateral line, 77 to 80.

Head rather small, a depression above upper eye at beginning of dorsal. Snout short, slightly produced but not so much as in $L$. angustirostris. Upper eye a little posterior to lower. Interorbital space not very high, slightly convex and covered with small ctenoid scales, its width equal to one-third of long diameter of upper eye. Maxillary reaching a little past front of lower eye. Fifteen or 16 teeth on left side of lower jaw, 4 or 5 on right side; 14 on left side of upper jaw, none on right side.

Dorsal beginning over anterior third of upper eye. Pectoral of right side from $1 \frac{1}{2}$ to $1 \frac{3}{5}$ in head, that of left side from 2 to $2 \frac{1}{2}$ in head. Caudal convex, slightly angulated at tips of outer rays. Scales of blind side cycloid, those of eyed side usually strongly ctenoid, sometimes cycloid on anterior part of back and cheek.

Color of eyed side uniform dark brown, or indistinctly blotched with lighter brown. Caudal usually colorless on blind side, but sometimes irregularly placed, and more or less conspicuous even on the blind side. In some these spots are very distinct, in others wholly obsolete. Blind side in life washed with rusty red. 
This is one of the most abundant of Japanese shore flounders, being everywhere common.

We have numerous specimens from Mororan, Hakodate, Aomori, Tsuruga, Onomichi, Yokohama, Tokyo, and Kobe. We have also a photograph of a specimen from Uzen in Echigo. Mr. Kitahara records it, in letter, from Obama in Kiusiu. The species is unusually variable.

(From Yokohama; yoko, flat; hama, beach.)

2O. VER EQUA Jordan and Starks.

Verqequa Jordan and Starks, Bull. U. S. Fish Comm., XX, 1904, p. 628 (achne).

Allied to Microstomus and to Limanda.

Body rather elongate, covered with very fine cycloid scales; lateral line with a small arch in front, without accessory dorsal branch; mouth small and with about 7 large blunt teeth in a single row on blind side; eyes close together, separated by a high naked ridge which is continued backward; gillrakers very small, not numerous; no anal spine; caudal rounded; eyes and color on right side.

\section{VER ÆQUA ACHNE Jordan and Starks.}

Veræqua achne Jondın and Starks, Bull. U. S. Fish Comm., XXII, 1904, p. 625, pl. vir, fig. 1 (Matsushima Bay).

\section{Habitat.-Matsushima Bay in deep water.}

Head, 4.33 in length; depth, 2.87; D. 85; A. 69; scales, 135; upper eye, 3.16 in head; snout from upper eye, 4; pectoral, 2 ; ventral, 4 ; highest dorsal rays, 2 ; caudal, 1.1 .

Form rather slender, the outlines forming low even curves; anterior upper outline of head unbroken and continuous with body curve; mouth very small, the maxillary reaching a little past front of lower eye but scarcely to edge of pupil; 7 large and very blunt teeth, set in a single row on blind side only; eyes narrowly separated by a high naked ridge, the lower the more anterior; interorbital ridge continued backward and upward along lower margin of upper eye, forming a high, conspicuous, smooth ridge; a slight angle on lower edge where it turns upward, but no tubercles developed; nostrils close together, in short broad tubes, anterior reaching to edge of preorbital; gill slit stopping at upper edge of pectoral; gillrakers very small -8 on lower limb of arch. Scales very fine, everywhere cycloid; very small nonimbricated scales present on dorsal and anal nearly to tips of rays except on the brown streak behind each ray; caudal thickly covered with similar scales; scales on pectoral rays only; on base of ventral only on both rays and membrane; small imbedded scales on snout; lateral line perfectly straight and horizontal to tip of pectoral, where it turns up and forms a low but conspicuous arch, the cord of its curve 3 times its height. Dorsal beginning slightly on blind side above middle of eye; 
low anteriorly, gradually growing higher to beginning of its last third or fourth, where it reaches its greatest height; pectorals rounded, that of eyed side, in our specimen, very slightly longer than that of blind

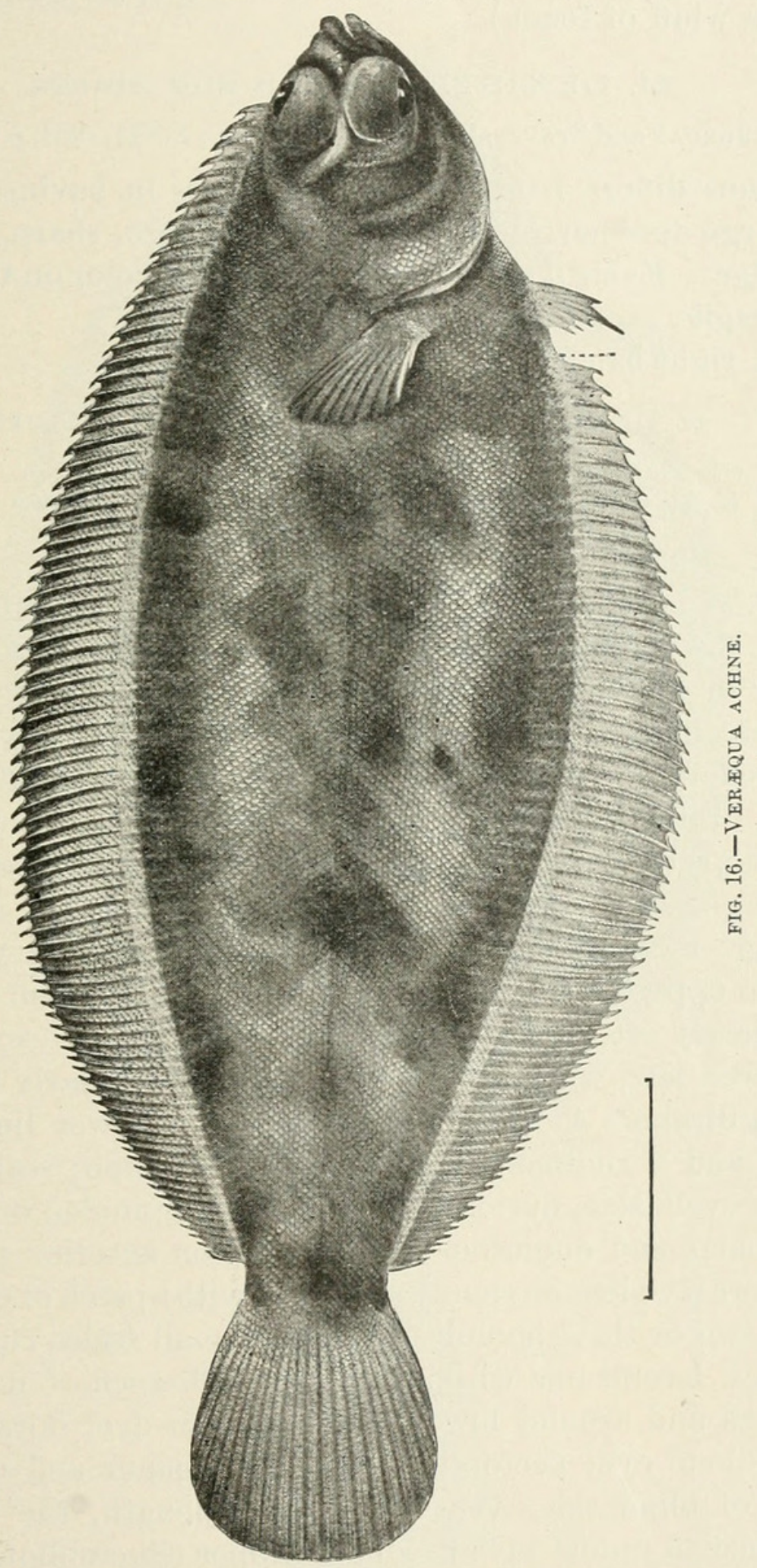

side; ventral short and rather broad, the second ray longest, making the fin pointed; caudal broadly rounded.

Color slaty brown, mottled with darker brown blended into the ground color; a brown streak behind and partly on each dorsal and anal ray; caudal uniform dark brown; pectoral with dark brown membrane. 
A single specimen, the type, dredged at station 3772, Matsushima Bay, in 79 fathoms. It is $18 \mathrm{~cm}$. in length, and is numbered 51447 U.S.N.M.

( $\alpha^{\prime} \chi v \eta$, a whiff of foam.)

21. DEXISTES Jordan and Starks.

Dexistes Jordan and Stanks, Bull. U.S. Fish Com., XXII, 1904, p. 624 (rikuzenius).

This genus differs from Pseudopleuronectes in having large scales, and the large eyes narrowly separated by a high, sharp, naked interorbital ridge. Eyeball scaly above. Eyes and color on the right side.

Body fragile.

( $\delta \varepsilon \dot{\varepsilon} \iota \dot{\circ}$, right handed.)

36. DEXISTES RIKUZENIUS Jordan and Starks.

Dexistes rikuzenius Jordan and Starks, Bull. U. S. Fish Com., XXII, 1904, p. 624, pl. vi, fig. 1 (Matsushima Bay, Suruga Bay).

Habitat. - Shores of eastern Japan in deep waters.

Head, 3.83 in length; depth, 2.75; D. 73; A. 59; scales 64 (pores); upper eye, 3.1 in head; snout from upper eye, 4.83 ; maxillary of eyed side, 3.83 ; of blind side, 3 ; pectoral of eyed side, 2 ; of blind side, 3 ; ventral, 3.1; highest dorsal rays, 2.5; median caudal rays, 1.5.

Body moderately narrow; anterior dorsal curve slightly broken by the raised orbital rim; snout blunt, lower jaw projecting, and with a knob developed at symphysis below tip; eyes large, upper slightly the larger and placed farther back; narrowly separated by a high sharp, naked ridge; mouth much larger on blind side; maxillary of eyed side reaching to opposite anterior edge of pupil; teeth blunt and not very even or closely set, in one moderately straight row except on blind side of lower jaw, where three or four are irregularly placed inside the row; gillrakers short and triangular, 7 on lower limb of arch, 1 developed and 2 rudimentary ones on upper limb; scales large and ctenoid on eyed side, cycloid on blind side; spinules on scales very slender, sharp, and numerous; a few scales on anterior part of interorbital where it widens on snout; upper eye with a patch of ctenoid scales, each with two or three spinules; a row of small scales running out on each fin ray; lateral line without an arch, a branch of it curves down behind eyes and around lower edge of lower eye; dorsal beginning above middle of eye; pectoral of eyed side longer and more pointed than that of blind side; ventrals equal in length, the last rays the longest; median caudal rays produced, upper edge obliquely truncate, lower slightly concave.

Color brown, with a few irregular inconspicuous dark brown spots, one on lateral line at beginning of its posterior two-fifths, one near base of caudal, one below middle of lateral line, one near top of pectoral; small ones show little color except a few brown spots, the one on lateral line the most conspicuous. 
The type from which this description is taken is $22 \mathrm{~cm}$. in length, and was taken at station 3774, in Matsushima Bay, in 84 fathoms. Two small cotypes were taken at station 3717, off Ose Point, Suruga Bay, in 65 to 125 fathoms.

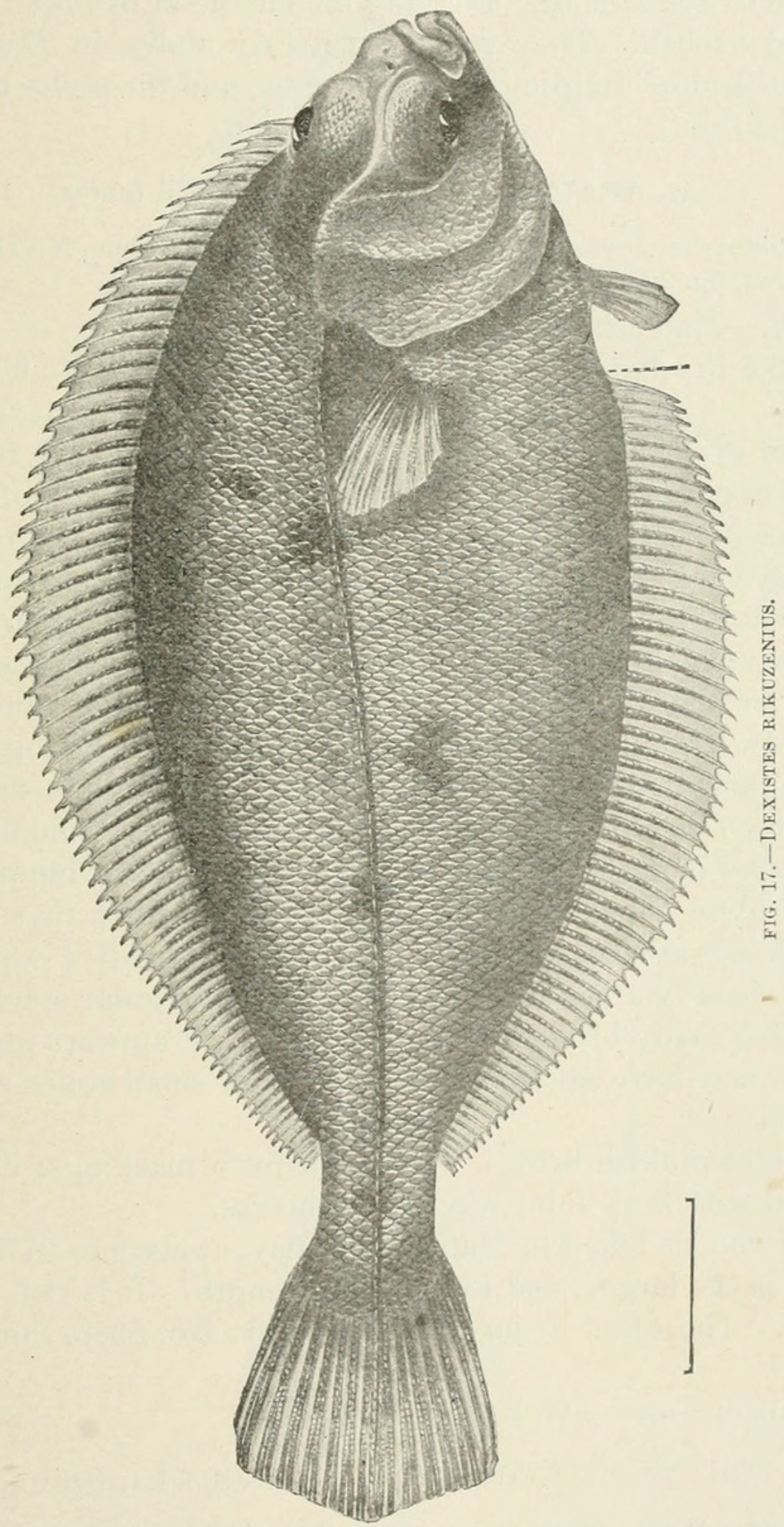

The type is Cat. No. 51423, U.S.N.M. A cotype is No. 8388, Stanford University.

(Name from the province of Rikuzen, in which Matsushima Bay is located. 


\section{ARAIAS Jordan and Starks.}

Araias Jordan and Starks, Bull. U. S. Fish Com., XXII, 1904, p. 624 (ariommus).

This genus is also a degenerate ally of Pseudoplenronectes. It is very close to Dexistes, the only tangible character of importance being the naked eyeball. The eyeballs are scaly above in Dexistes. The body is still more fragile than in Dexistes, and the scales are thinner.

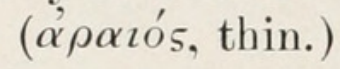

\section{ARAIAS ARIOMMUS Jordan and Starks.}

Araias ariommus Jordan and Starks, Bull. U. S. Fish Com., XXII, 1904, p. 624, pl. vi, fig. 2 (Matsushima Bay).

Habitat.-Matsushima Bay in deep water.

Head, 3.8 in length; depth, 2.6; D. 71 to 74 ; A. 57 to 60 ; scale, 60 ; upper eye, 2.8 in head; snout from upper eye, 4.33; maxillary, 3.75; pectoral of eyed side, 1.87; of blind side, 2.75 ; caudal, 1.16 .

Rim of upper orbit very slightly protruding above rest of upper profile; eyes separated by a narrow sharp ridge; anterior rim of lower eye scarcely or very slightly anterior to that of upper, posterior rim anterior to that of upper (to a greater degree in the type than in cotype); mouth very-small, considerably larger on blind side, the maxillary reaching to just below anterior edge of orbit; teeth blunt, set in a single, very irregular row, those of lower jaw projecting around on eyed side farther than those of premaxillary; gillrakers short and triangular, $3+7$ on first arch; dorsal beginning above middle of upper eye; pectoral of eyed side a little longer and not so bluntly rounded as that of blind side; caudal doubly truncate, median rays the longer; lateral line not arched, gradually curved up anteriorly; scales cycloid, with occasionally a ctenoid scale with long irregular spinules (as the spinules are easily broken, leaving no trace, it appears probable that the scales may have all been ctenoid); a few small scales running out on fin rays.

Color light pinkish brown, without definite markings; dorsal, anal, and caudal with very faint wavy cross marks.

Two specimens taken in Matsushima Bay, at stations 3770 and 3773. The type is the larger, and is $13 \mathrm{~cm}$. in length. It is Cat. No. 51417, U.S.N.M. The other from station 3773 is No. 8386, Stanford University.

(ฉ̈pr, large; ö $\mu \mu \alpha$, eye.)

\section{PLEURONECTES (Artedi) Linnæus.}

Pleuronectes Artedi, Genera, etc., in part, 1738, p. 16.

Pleuronectes Linneus, Syst. Nat., 10th ed., 1758, p. 268 (platessa); included all known Pleuronectidx.

Platessa Cuvier, Règne Animál, 1st ed., II, 1817, p. 220 (platessa).

Pleuronectes Swainson, Nat. Hist. Class'n Anim., II, 1839, p. 302 (platessa).

Pleuronectes Bleek er, Comptes Rendus Acad. Amsterd., XIII, 1862 (platessa); and of most recent authors. 
Body oblong, with firm flesh. Mouth small, teeth uniserial, incisorlike, compressed, forming a continuous cutting edge. Lateral line straightish, without arch or accessory dorsal branch. Scales imper-

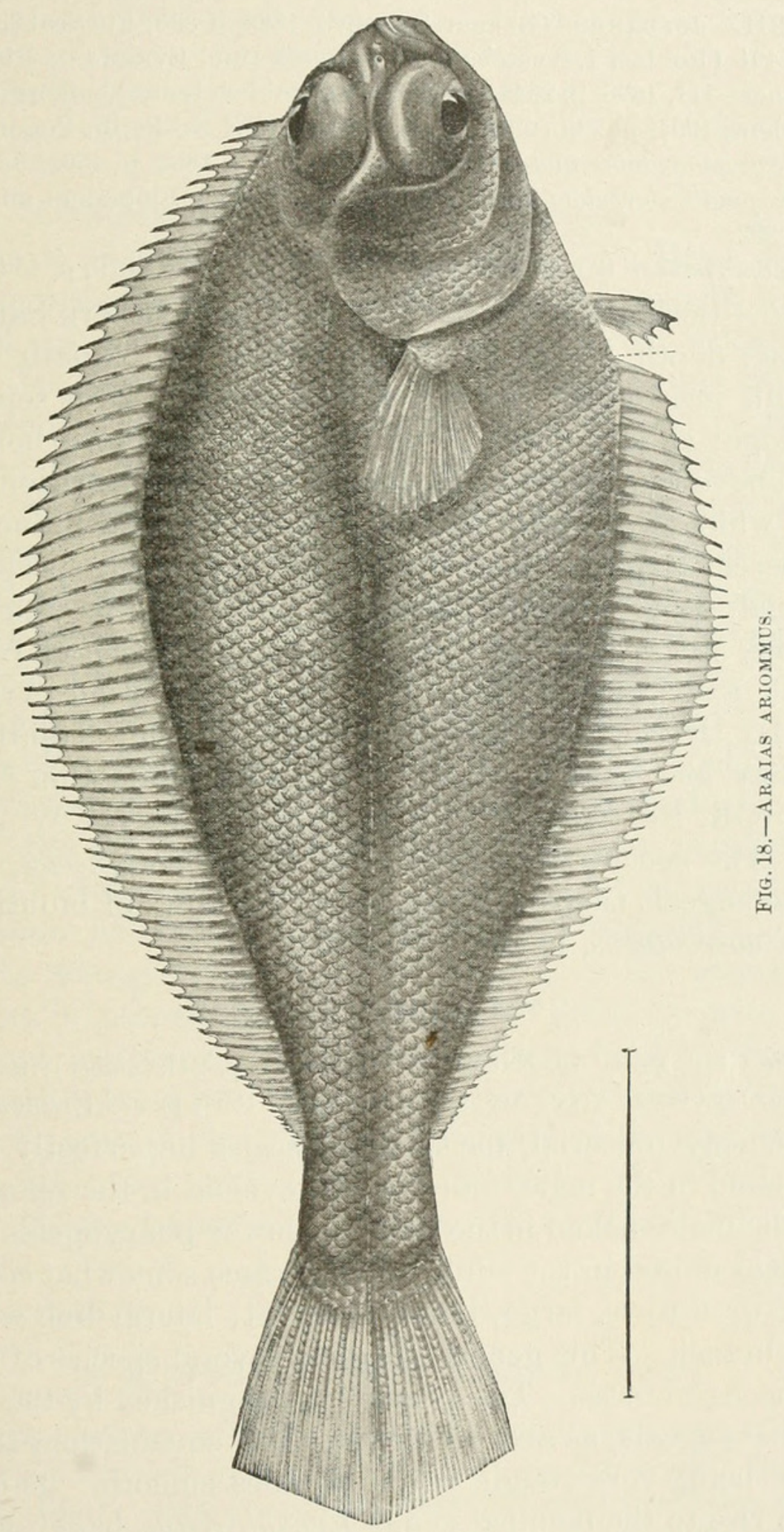

fectly imbricated, chiefly cycloid in both sexes; lower pharyngeals small and narrow, separate, each with one or two rows of small bluntish teeth. No stellate scales along bases of dorsal and anal. A row of bony tubercles behind eye. Species mostly European, valued as food, typified by the common Plaice, Pleuronectes platessa.

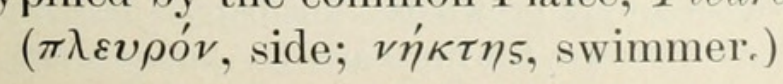




\section{PLEURONECTES QUADRITUBERCULATUS Pallas.}

Pleuronectes quadrituberculatus Pallas, Zoogr. Rosso-Asiat., III, 1811, p. 423 (sea between Kamchatka and Alaska).-Bean, Proc. U. S. Nat. Mus., 1881, p. 241.-Jordan and Gilbert, Synopsis, 1883, p. 836; Fur Seal Expl., III, 1898, p. 491 (Robben I, Avatcha Bay).-Jordan and Evermann, Fish North Mid. Amer., III, 1898, p. 2648 (Bering Sea; Robben I, etc.).-Sснмidt, Pisc. Mar. Orient, 1904, p. 239 (Gulf of Aneiva, Gulf of Sakhalin, Popora).

Parophrys quadrituberculatus Günther, Cat., LV., 1862, p. 456.

Platessa quadrituberculata Jordan and Goss, Review Flounders and Soles, 1889, p. 292.

Pleuronectes pallasii Steindachner, Ichth. Beitr., VIII, 1879, p. 45 (Kamchatka).

Habitat.-Bering Sea, Japan Sea, south to Southern Sakhalin.

Head, $3 \frac{2}{3}$; depth, 2. D. 68; A. 50; scales, 78. Mouth very small, with small, incisor-like teeth, rounded at tip. Eyes separated by a narrow ridge; about 5 small, prominent, conical, obtuse, bony tubercles in a row above the opercle, continuous with the direction of the lateral line, which is straight, without accessory dorsal branch; tubercle above opercle largest. Scales small, cycloid in all specimens examined. Anal spine present. Grayish, mottled with paler and with round black spots; fins very dark. Bering Sea on both coasts, south to Kodiak and Okhotsk Sea. Our specimens from Avatcha Bay, Bristol Bay, Herendeen Bay, Chernofsky Harbor, Grantley Harbor, Chignik Bay, and Robben Island. The above description from a small specimen (Cat. No. 28025, U.S.N.M.) collected by Mr. W. J. Fisher at Kodiak. The species proves to be a true Pleuronectes, having the lower pharyngeals narrow, separate, with 2 rows of bluntish teeth.

(quadrituberculatus, having four tubercles.)

\section{LIOPSETTA Gill.}

Liopsetta Gill, Proc. Ac. Nat. Sci. Phila., 1864, p. 217 (glaber); females.

Euchalarodus GrLL, Proc. Ac. Nat. Sci. Phila., 1864, p. 222 (putnami); males.

Teeth chiefly uniserial, incisor-like; scales imperfectly imbricated, rough ctenoid in the male, more or less cycloid in the female (fin rays scaly in the male, naked in the female); lower pharyngeals very large, more or less united in the adult, their surface somewhat concave, with teeth in 5 or 6 rows, large, blunt, close set; lateral line without arch or dorsal branch. This genus comprises several species of small flounders of the Arctic seas. The genus is distinguished by the large, halfunited pharyngeals, as also by the peculiar squamation, the scales in the males being very rough, in the females smooth. This difference has given rise to the nominal genus Euchalarodus, based on the males, while Liopsetta was based on the smoother females, which were erroneously supposed to be scaleless.

( $\lambda \varepsilon \tilde{\imath} o s$, smooth; $\psi \tilde{\eta} \tau \tau \alpha$, flounder.)

KEY TO SPECIES.

a. Dorsal rays 59 to 62 ; anal 45 to 46 ; scales 80 , dark brown, the fins barred .obscura. 39 aa. Dorsal rays 58; anal rays 38 ; scales 70 ; brown, the fins barred...pinnifasciata. 40 


\section{LIOPSETTA OBSCURA (Herzenstein).}

Pleuronectes obscurus Herzenstein, Mélanges Biologiques, 1890, p. 127 (Chemulpo, Vladivostok).

Liopsetta obscura JoRdan and Gilbert, Rep. Fur Seal Invest., III, 1898, p. 492 (Iturup).-Jordan and Evermann, Fish North Mid. Amer., III, p. 2657 (Iturup).-Jordan and SNyder, Proc. U.S. Nat. Mus., XXIII, 1900, p. 379 (Iturup).-Sснмгdт, Pisc. Mar. Orient., 1904, p. 244 (Vladivostok, Mayka, Chemulpo).

Habitat.-Okhotsk Sea, south to Kuril Islands.

Dorsal rays, 59 to 62 ; anal, 45 to 46 ; tubes, 79 . Head, $3 \frac{9}{10}$; depth, $2 \frac{1}{5}$; scales in males everywhere strongly ctenoid, smooth in females; interorbital space covered with very fine scales, not naked; curve of the lateral line marked, its cord contained 5 times in the straight portion; the pectoral of colored side $1 \frac{3}{5}$ head, the caudal $1 \frac{1}{6}$, the ventral $\frac{1}{2}$ head, and the highest dorsal ray $1_{5}^{2}$. Lower pharyngeals short and broad, the two closely appressed but united in our specimens, 27 and $29 \mathrm{~cm}$. long. The teeth are large and very blunt, like cobble stones, and are arranged in 1 row along the outer edge, a row of larger teeth along the inner edge, and a short row along the posterior edge of the triangle. Color on eyed side uniform dark brown on body and fins, the extreme tips of the fin rays white; on blind side yellowish white, with a few irregular scattered dark spots; dorsal and anal yellowish at base, becoming more or less mottled with dusky on distal half, the fins marked with broad dark bars parallel with the rays, about 7 on the anal fin, 10 or 11 on the dorsal; caudal light on basal half more or less blotched with darker, becoming black posteriorly. The young from 9 to $15 \mathrm{~cm}$. long have the scales perfectly smooth, but in other respects they agree perfectly with the adult males, except in their more varied coloration; head and body brownish, profusely spotted in coarser or finer pattern with light gray; also with a few scattered black spots edged with gray; markings on the fins as described for adults. Sea of Okhotsk. Our specimens from Shana Bay, Iturup Island, one of the Kurils, originally described from Vladivostok.

(obscurus, dark.)

\section{LIOPSETTA PINNIFASCIATA (Kner).}

Pleuronectes pinnifasciatus KNER, in Steindachner, Ueber einige Pleuronectiden, etc., aus Decastris Bay, 1870, p. 422, pl. I, fig. 1 (Decastris Bay, mouth of Amur River).-_Jordan and Goss, Review Flounders and Soles, 1889, p. 290Jordan and Evermann, Fish North Mid. Amer., III, 1898, p. 2649.

Liopsetta pinnifasciata Sснмпdт, Fauna Mer. Okhot. Japan, 1903, p. 19 (Okhotsk Sea); Mar. Orient, 1904, p. 245 (mouth of Amur, Lintog, Busse Bay, etc.).

Habitat.-Japan Sea, from Amur River to Kamchatka.

Head, $3 \frac{1}{4}$ in body; depth, $2 \frac{1}{6}$. D. 58 ; A. 38 ; scales, 70 ; eye, $5 \frac{2}{3}$ in head; the highest anal ray, 2; pectoral, 2; caudal, $4 \frac{1}{2}$ in body. Body 
subelliptical, the snout rather pointed and not forming an angle above eye; mouth rather small, maxillary reaching scarcely to the middle of the lower eye; interorbital space rather broad, one-half width of eye; a rather prominent rugose ridge above opercle, with a smaller similar ridge behind it; both sides of jaws with teeth, those on blind side stronger; origin of dorsal over middle of upper eye. Color brown, with vague dusky spots; 6 or 7 blackish vertical bars on dorsal and anal; similar lengthwise blotches on caudal. Okhotsk Sea, east to Kamchatka (Steindachner.) Not seen by us.

Schmidt refers the species to Liopsetta, to which it probably belongs. (pinna, fin; fasciatus, banded).

\section{PLATICHTHIYS Girard. '}

Platichthys Girard, Proc. Ac. Nat. Sci. Phila., 1854, p. 136 (rugosus=stellatus).

Body very robust, broad, not greatly compressed. Mouth small; teeth chiefly uniserial, incisor-like. Scales all in both sexes and on both sides of body reduced to coarse scattered stellate tubercles, which are not imbricated; similar tubercles between bases of dorsal and anal rays; lateral line without scales, with no anterior arch or accessory lateral line; lower pharyngeals broad, each with 3 rows of blunt coarse teeth. A single species, the largest of the small-mouthed flounders, and distinguished from related forms chiefly by the development of coarse stellate tubercles instead of scales.

$\left(\pi \lambda \alpha \tau \dot{v}_{5}\right.$, flat; $i \chi \theta v^{\prime}$, fish.)

\section{I. Platichthys STEllatus (Pallas).}

TAKANOHAGAREI (HAWK'S CREST FLOUNDER); NUMAGAREI (SWAMP FLOUNDER).

Pleuronectes stellatus Pallas, Zoographia Rosso-Asiatica, III, 1811, p. 416 (Kamchatka, Aleutian, and Kuril Islands).-Günther, Cat., LV, 1862, p. 443.Steindachner, Pleur. von Decastris Bay, 1870, p. 1.-Jordan and Gilbert, Proc. U. S. Nat. Mus., III, 1880, p. 453; IV, 1851, p. 68.-Bean, Proc. U.S. Nat. Mus., IV, 1881, p. 420.-Jordan and Gilbert, Synopsis, 1883, p. 835.Bean, Proc. U. S. Nat. Mus., VI, 1883, p. 353; Cat. Coll. Fish., U. S. Nat. Mus., 1883, p. 20.-Jordan, Nat. Hist. Aquat. Anim., 1884, p. 184, pl. xlvi.Oтакі, Journ. Bureau Fish, 1897, p. 7, pl. vi, fig. 6 (Northern Japan).Ishikawa and Matsu'üra, Prel. Cat., p. 25 (Hokkaido).

Platessa stellata De Kay, N. Y. Fauna, Fishes, 1842, p. 301.-Storer, Synopsis, 1846, p. 478.

Platichthys stellatus Lockington, Rep. Com. Fish. Cal., 1878-79, p. 43; Proc. U. S. Nat. Mus., 1879, p. 91.-Jordan and Goss, Review Flounders and Soles, 1889, p. 296.-Jordan and Evermann, Fish. North. Mid. Am., 1898, III, p. 2652 (Robben I., Saghalin, Alaska, California, etc.).-Jordan and Gilbert, Fur Seal Explr., III, 1898, p. 492 (Alaska, etc.).-JoRdAN and Snyder, Proc. U. S. Nat. Mus., XXIII, 1900, p. 379 (Robben I).-Schmidt, Faune Pisc. Mar. Orient, 1904, p. 240 (Japan Sea; Ochotsk Sea; Vladivostok; Mayka; Makhodka; Arakul; Shumanshin; Amur River; Petropaulsky; Hakodate; Saghalin).

Platichthys rugosus Girard, Proc. Ac. Nat. Sci. Phila., 1854, pp. 139, 155 (San Francisco; Presidio; Petaluma).-Girard, U.S. Pac. R. R. Surv., X, Fishes, 1858, p. 148. 
Habitat.- North Pacific on both coasts, south to Tokyo and to San Luis Obispo.


and short, the snout forming a slight angle with the profile; lower jaw projecting; interocular space rather broad, with very rather rough scales; large rough scales at base of dorsal and anal rays and on sides of head; similar but smaller scales scattered over the body; lateral line smooth; fine without scales; a cluster of bony prominences above opercle. Teeth incisor-like, truncate, rather broad, $\frac{10+15}{12+16^{\circ}}$ Lower pharyngeals broad, with coarse paved teeth. Dark brown or nearly black, with lighter markings; fins reddish brown; dorsal and anal with 4 or 5 vertical black bands; caudal with 3 or 4 black longitudinal

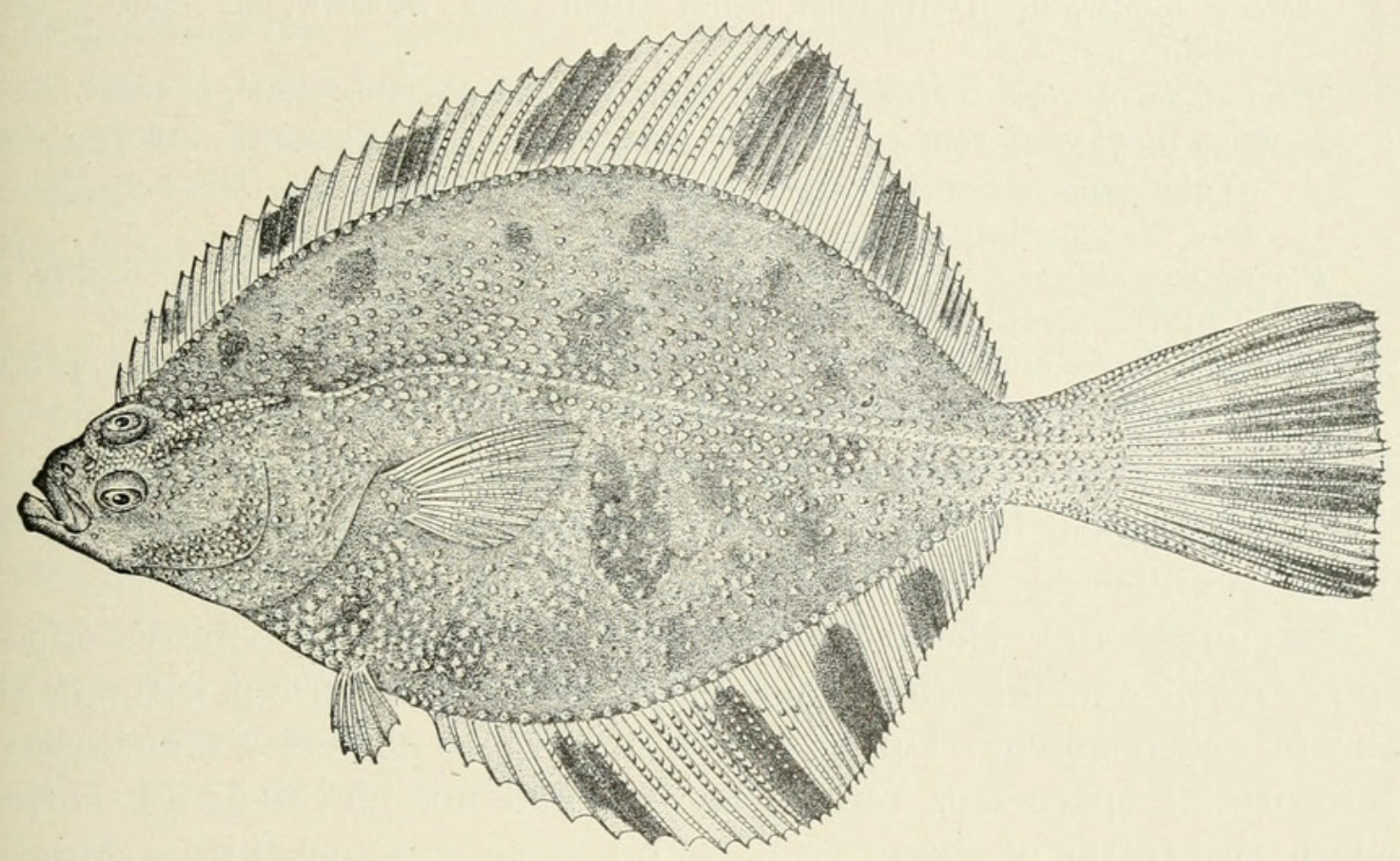

Fig. 19.-Platichthys stellatus.

bands. Pacific coast of America, from Point Concepcion to the Aretic Ocean and south to northern Japan. This is one of the largest of the American flounders, reaching a weight of 15 to 20 pounds. Of the small-mouthed flounders it is much the largest species known. It is an abundant species, constituting half the total catch of flounders on the Pacific coast of America, and it is equally abundant in Bering Sea. It lives in shallow water and sometimes ascends the larger rivers. It is one of the most widely distributed of all the flounders, its range extending from San Luis Obispo, California, to the mouth of the Anderson and Colville rivers on the Arctic coast, and to Port Clarence, thence across to Japan, whence we have specimens from Mororau, Hakodate, Aomori, Same, Matsushima, and Tokyo. We have also specimens from Petropaulski, Bering, Medni, and Robben islands. Also seen from Bristol Bay and Saghalon. It is a coarse fish, not valued as food, either in Japan or America.

(stellatus, starred.) 
26. KAREIUS Jordan and Snyder.

Kareius Jordan and Snyder, Proc. U. S. Nat. Mus., XXIII, 1900, p. 379 (scutifer $=$ bicoloratus).

This genus is allied to Pleuronectes and Liopsetta, differing in the scaleless body, the adult having two or three irregular bony or warty areas on the eyed side. Teeth even, in one row.

(karei, flounder in Japanese.)

42. KAREIUS BICOLORATUS (Basilewsky).

ISHIGAREI (ROCK FLOUNDER); MAKOGAREI (MAKO FLOUNDER); YANAGIMUSHIGAREI (WILLOW WORM FLOUNDER).

Platessa bicoloratus Basilewsky, Nom. Mem. Soc. Moscow, X, 1855, p. 260 (Shantung).

Pleuronectes bicoloratus Herzenstein, Bull. Ac. Sci. Petersb., 1890, p. 133.

Kareius bicoloratus Jordan and Snyder, Proc. U. S. Nat. Mus., 1901, p. 769

(Yokohama).--Sснмгdт, Pise. Mar. Orient, 1904, p. 243 (Gensan, Hakodate, Manchuria).

Pleuronectes scutifer Steindachner, Sitzber. Akad. Wiss. Wien, XXI, p. 628, pl. II (Chifu).--Otaki, Journ. Bur. Fish, 1897, VII, pl. vi, fig. 5 (Japan).

Kareius scutifer Jordan and $\mathrm{SN}_{\mathrm{N}}$ Der, Proc. U. S. Nat. Mus., XXIII, 1901, p. 379 (Tokyo); Check List, 1901, p. 122 (Hakodate, Yokohama).

Habitat.--Coasts of Japan, south to Tokyo, also in northern China. Head, $3 \frac{1}{2}$ inches in length to base of caudal; depth, $2 \frac{2}{5}$. Eye, $5 \frac{1}{2}$ in head; maxillary, 4; snout, 5; dorsal, 69 ; anal, 50.

Body moderately slender, the upper anterior outline concave opposite front of eye, and the snout somewhat produced, but without an abrupt sharp notch. Upper eye slightly more posterior than lower. Interorbital space flat, rather narrow, and not elevated; its entire width two-thirds of diameter of pupil, bone only one-third. Mouth arched; maxillary reaching to below anterior edge of pupil of lower eye. Teeth compressed and set in a single, even, row on both sides of jaws; the row on eyed side not so long as that on blind side. Gill rakers short and pointed; 4 or 5 on lower limb of arch. Origin of dorsal above anterior edge of upper eye or slightly posterior to edge. Pectoral of eyed side usually somewhat pointed at ends of upper rays; its length contained $1 \frac{4}{5}$ in head. Pectoral of blind side rounded, its length $2 \frac{3}{4}$ in head. Ventrals reaching to front of anal, that of blind side slightly the more anterior. Caudal truncate or very slightly convex.

A row of contiguous, rough plates between lateral line and outline of back, following the contour of the latter and running back to a little past middle of entire length. A shorter row of smaller plates, which are not in a contiguous row, but irregularly separated, is on lower part of side; its length considerably shorter than that of head. A row of narrow plates follows lateral line immediately above and below; the rows not at all continuous, but separated (sometimes 
widely) at irregular intervals, and when separated the interval is filled by a dermal channel. One or two plates on base of pectoral and often one or two a short distance below and behind base. A few plates on each edge of caudal peduncle. Plates irregularly scattered over opercle and preopercle, an area just behind eyes, and sometimes on interorbital space, covered by thin skin, and apparently the roughened bones of the cranium. The skin otherwise smooth and naked.

Specimens up to $9 \mathrm{~cm}$. in length are entirely smooth. In specimens from 10 to $12 \mathrm{~cm}$. long the ridge running back from the interorbital space is becoming rough. Specimens from 14 to $16 \mathrm{~cm}$. long have the row of rough plates on the back well developed, but not so conspicuous as in the adult; the row on lower part of sides and the rows along lateral line appearing. In one specimen $22 \mathrm{~cm}$. long the ventral and lateral series have not developed. Apparently the last plates to appear are those on base of pectoral and on preopercle, though occasionally they are slightly developed in specimens $15 \mathrm{~cm}$. long. All of the plates become more elevated and rougher with age.

Color uniform, brown or drab, often irregularly flecked with dark spots on the fins and body. These more conspicuous, and probably always present in the young. Usually a row of round white spots, set at rather wide intervals, follows the dorsal and ventral outlines of the body at a short distance from the base of the fins, and often other light spots are scattered irregularly over the body.

Specimens from Tokyo, Otaru, Aomori, Hakodate, Same, Matsushima, and Mororan, and the largest $27 \mathrm{~cm}$. in length. The species is generally common in northern Japan and in northern China.

(bis, two; coloratus, colored.)

\section{CLIDODERMA Bleeker.}

Clidoderma BleEker, Comptes Rendus, Amsterd., XIII, 1862 (asperrima).

'This genus is allied to Pleuronectes. Its principal character is the presence in the adult of many warty tubercles, the largest arranged in about 6 longitudinal rows. The very young are naked; the very old, almost evenly warty. The body is broader than in most related genera.

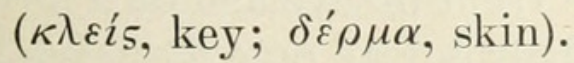

\section{CLIDODERMA ASPERRIMUM (Schlegel).}

Platerra asperrima Schlegel, Fauna Japan, Paris, 1846, p. 172 (Nagasaki).

Pleuronectes asperrimus Günther, Cat. Fish, IV, 1862, p. 453 (copied)-Namiye. Class. Cat., 1881, p. 110 (Tokyo).-ОтакI, Journ. Fish. Bur., 1897, p. 7, pl. viri, fig. 8 (Tokyo).

Clidoderma asperrimum Jordan and Snyder, Proc. U. S. Nat. Mus., XXIII, 1900, p. 379 (Tokyo).-Jord.in and Starks, Bull. U. S. Fish Com., XXII, 1904, p. 625 (Matsushima Bay).

Habitat.-Coasts of Japan, chiefly northward. 
Head, 3 in length to base of caudal; depth, $1 \frac{4}{5}$. Upper eye, 5 in head; maxillary, $3 \frac{2}{3}$; snout to upper eye, $4 \frac{1}{4}$.

Gape nearly straight, curved down under tip of snout. Teeth bluntly pointed and irregular; in a single uneven row on eyed side of mandible, which is straight and higher than the curved, blind side of mandible, and shuts well past and within the premaxillary teeth of the eyed side; in 2 uneven rows on blind side of mandible, those of the outer row much the larger; in two rows on premaxillary of blind side similar to those of blind side of mandible; and in two very irregular rows on premaxillary of eyed side similar to the small inner row on blind side. Maxillary of ey ed side reaching to opposite front of pupil; its length two-thirds of that of blind side, which reaches almost to posterior margin of eye and is contained $2 \frac{1}{3}$ times in head. Interor-

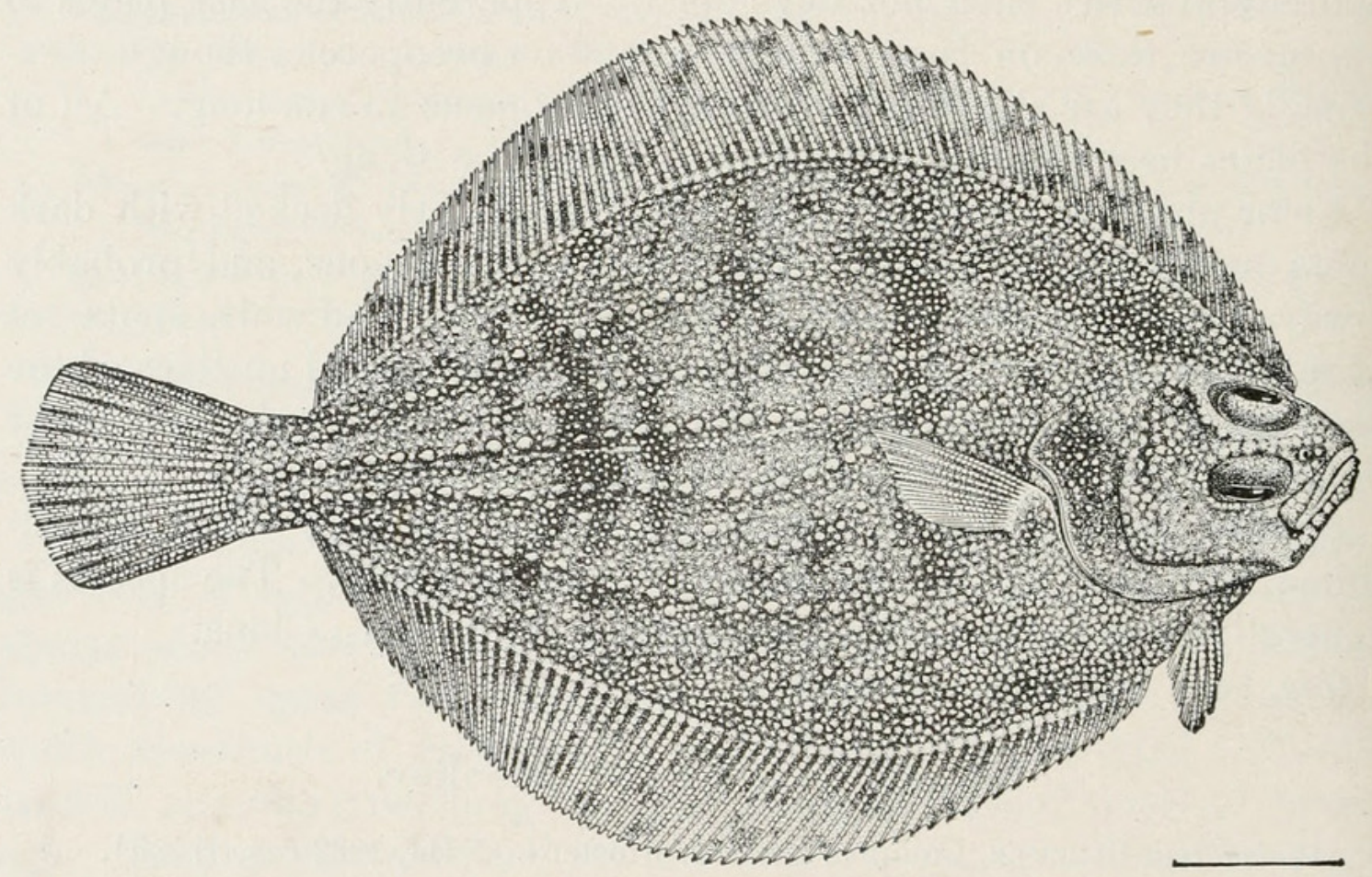

Fig. 20.-Clidoderma ASPERrimum.

bital space very narrow, but not sharp, continued back as a blind ridge behind upper eye. Gill rakers short, conical, and sharp, their number $4+10$.

Origin of dorsal on blind side opposite front of eye and on a level with posterior nostril of blind side. Highest dorsal rays $2 \frac{3}{4}$ in head; a little shorter than highest anal rays. Pectorals broadly rounded; that of eyed side $2 \frac{1}{2}$ in head, that of blind side $2 \frac{4}{5}$. Caudal rounded or double truncate. Body and everywhere on head, including snout, mandible, maxillary, and interorbital space, very rough with close-set bony plates. Larger plates, their tops more conical and extending above the others, are arranged in 5 or 6 rather definite longitudinal series. The bases of all the fins on eyed side and the surface of the eyeballs with fine, rough plates. Lateral line with a low curve ante- 
riorly, but not angulated at posterior end of curve. Blind side of body with thin, smooth, naked skin.

Color dark brown with some indefinite blotches of darker.

Here described from a specimen $34 \mathrm{~cm}$. in length from Mororan We have specimens from Mororan, Hakodate, Aomori, Matsushima Bay, and Tokyo.

(asperrimus, very rough.)

\section{MICROSTOMUS Gottsche.}

Microstomus Gotтsche, Archiv fur Naturgesch., 1835, p. 150 (latidens); not Microstoma Risso, 1826.

Cynicoglossus Bonaparte, Fauna Italica, 1837, Pt. 19 (cynoglossus Nilsson, not of LinNeUs).

Cynoglossa Bonaparte, Catalogo Metodico Pesci Europei, 1846, p. 48 (microcephalus); not Cynoglossus Hamiton, 1822.

Brachyprosopon Bleeker, Comptes Rendus Acad. Sci. Amsterd., XIII, Pleuron., p. 7, 1862 (microcephaius).

Body elongate, compressed; mouth very small; teeth broad, incisorlike, on blind side only; scales small, all cycloid; vertebræ numerous (48 to 52); dorsal rays, 90 to 100 ; anal rays, 70 to 85 ; anal spine obsolete; left side of skull normal, without mucous cavities; ventral fins with 5 rays each. Arctic seas. This genus is widely separated from Pleuronectes and its allies by its greatly increased number of vertebræ, a character accompanied by a similar increase in the number of fin rays. It is close to Glyptocephalus, but the lack of the cavernous structure of the bones of the head, a structure peculiar to the species of that genus sufficiently distinguishes it.

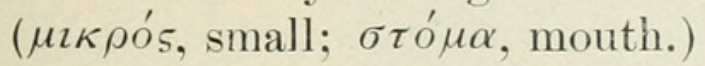

KEY TO SPECIES.

a. Body slender and fragile, the depth $3 \frac{1}{2}$ in length; dorsal rays about 93 ; anal 80 ; scales 90 ; color uniform ................................. kitahar 4 . 44

aa. Body rather robust, the depth $2 \frac{1}{2}$ in length. Dorsal rays about 92 ; anal 76 ; scales 112; color brown, often blotched with rusty red............ stelleri, 45

44. MICROSTOMUS KITAHARÆ Jordan and Starks.

Pleuronectes cynoglossus Otaki, Journ. Fish. Bur., 1897, p. 7, pl. vi, fig. 7 (Japan; not of LinNeus.)

Mirostomus kitaharæ Jordan and Starks, Bull. U. S. Fish. Com., XXII, 1904, p. 625, pl. vir, fig. 2 (Matsushima Bay, Suruga Bay, Tsuruga, Japan Sea; Tokyo).

Habitat.-Coasts of northern Japan south to Tsuruga.

Head, 4.25 to 4.5 in length; depth, 3.5 to 3.75 ; D. 91 to $96 ;$ A. 75 to 83 ; scales, 87 to 96 (pores); eye, 2.83 to 3.16 in head; snout from upper eye, 4.33 to 4.75 ; maxillary, 3.75 to 4 ; pectoral of eyed side, 1.83 to 2.33 , of blind side, 2.25 to 3 ; ventral, 3.5 ; caudal, 1.25 .

Anterior upper profile evenly convex; the upper eye protruding above it; lower eye much in advance of upper, the eyes separated by

Proc. N. M. vol. $\mathrm{xxxi-06-15}$ 
a very narrow ridge; maxillary short, rather strongly curved, reaching to below anterior edge of pupil of lower eye; teeth rather blunt, in a single row, forming a continuous even cutting edge; a small bony knob developed below tip of mandible; anterior nostril of eyed side in

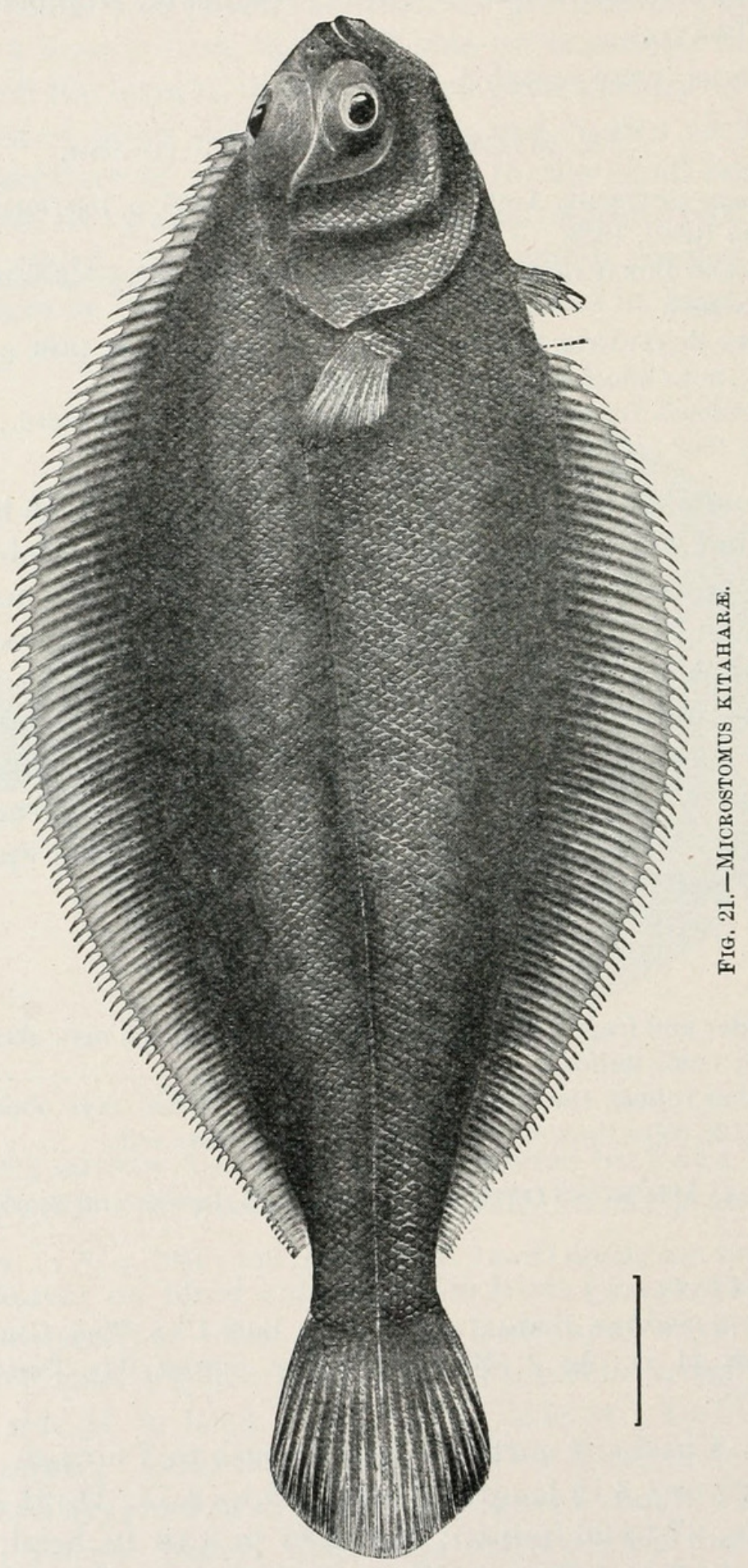

a short broad tube; gillrakers very short, 8 of them on lower limb of arch; scales everywhere cycloid, the snout, maxillary, and mandible naked; lateral line conspicuous, curving up just behind tip of pectoral above upper end of gill opening, but not at all arched; dorsal begin- 
ning above posterior margin of pupil of upper eye; the longest dorsal and anal rays are at beginning of posterior fourth of body length; pectoral narrow, pointed, variable in length, the upper edge of its base distant one diameter of pupil from upper end of gill slit; ventrals reaching just to front of anal; caudal rounded or double truncate, the middle rays projecting beyond outer rays a distance slightly greater than half eye.

Color uniform brown, pectoral and caudal growing black toward tips of rays; no color on blind side except black toward end of caudal.

The type is $18 \mathrm{~cm}$. in length, taken with several cotypes at station 3770 , Matsushima Bay, in 42 to 45 fathoms. Other cotypes were taken near the same locality at stations 3769,3771 (in 61 fathoms), and 3772 (in 79 fathoms); at station 3717, off Ose Point, Suruga Bay, in 65 to 125 fathoms, and station 3699, Suruga Bay, in 400 to 726 fathoms; others were collected by Jordan and Snyder in the market at Tokyo, several of which were deposited as cotypes in the Imperial University at Tokyo. Dried salted specimens were obtained in the market of Tsuruga.

Type. Cat. No. 51418, U.S.N.M. Cotypes are Nos. 8390, 8995, 8996, Stanford University.

(Named for Mr. T. Kitahara, of the Imperial Bureau of Fisheries of Japan.)

\section{MICROSTOMUS STELLERI Schmidt.}

BABAGAREI (OLD WOMAN FLOUNDER).

Microstomus stelleri Sснмпрт, Pisc. Mar. Orient, 1904, p. 247 (Mayka, Gensan, Shogun, Lake Askold, Shendogan, Gulf of Broughton, Gulf of Aneva.)

Habitat. - Northern Japan to Sakhalin and Korea.

Head, $4 \frac{1}{2}$ in length to base of caudal; depth, $2 \frac{1}{2}$. Upper eye, $4 \frac{1}{3}$ in

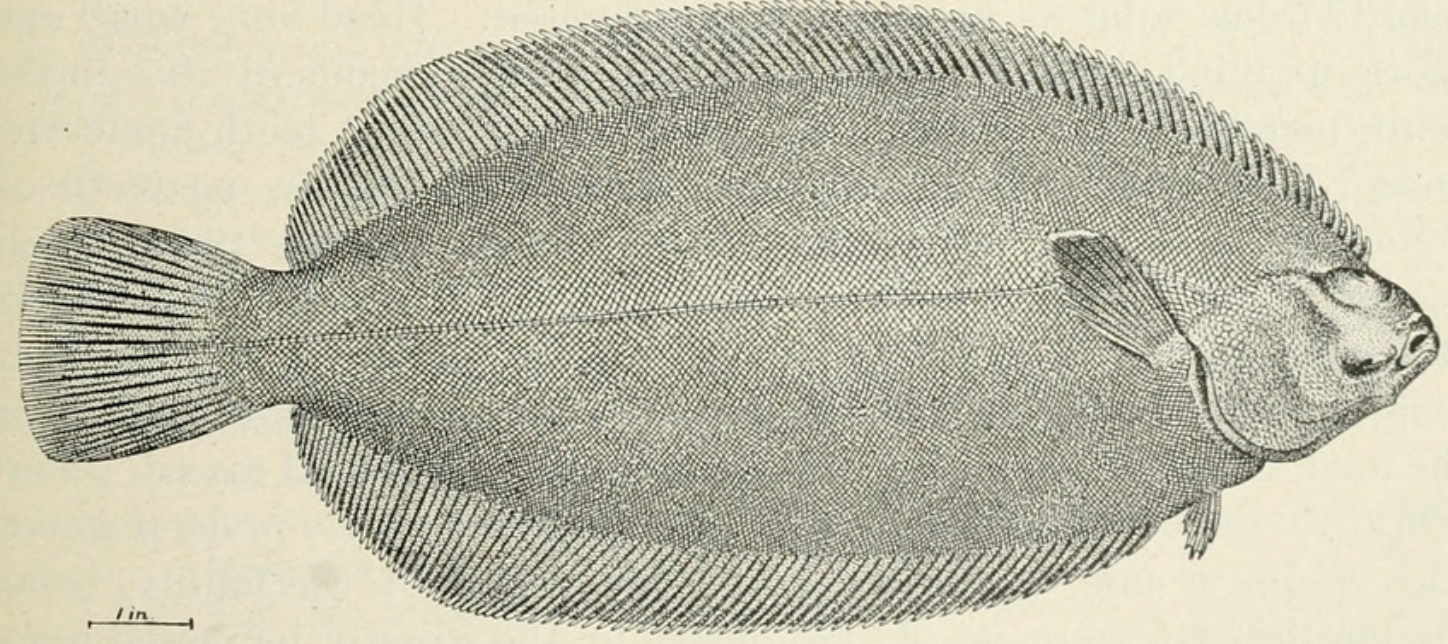

Fig. 22.-Microstomus stelleri.

head; snout to upper eye, $4 \frac{2}{3}$; interorbital space, $8 \frac{1}{2}$; interorbital bone, 19; maxillary, $4 \frac{3}{4}$; dorsal, 92; anal, 76; pores in lateral line, 112.

Mouth small and curved, the maxillary reaching to below front of lower eye. Teeth on blind side of jaws, extending very slightly around 
on colored side, especially on lower jaw; 12 to 14 teeth on mandible, 10 to 12 on premaxillary. They are strong and blunt in a single even row, forming a continuou cutting edge. Upper eye a little posterior to lower; interorbital space rather wide and convex, the bone narrow but not sharp, continued backwards and upwards on head behind eyes as a blunt, scaled ridge. Gillrakers short and pointed, $6+10$ in number.

Origin of dorsal opposite middle of eye and slightly on blind side of body. Longest dorsal rays equal in length to those of anal and contained $2_{5}^{2}$ times in head. Pectoral usually rounded, its length $1 \frac{1}{2}$ in head; that of blind side 2. Caudal rounded, slightly angulated at ends of outer rays. Lateral line with a low arch anteriorly; length of arch contained $5 \frac{1}{3}$ in straight part of lateral line; its height $\frac{1}{2}$ the long diameter of upper eye.

Color brown, indistinctly mottled with darker brown; some specimens show a dark blotch on lateral line at tip of pectoral, another just behind middle of straight part of lateral line, and very inconspicuous blotches at base of dorsal and anal fins. Blind side more or less spotted and soiled with dusky brown; the blind side of the vertical fins always dark. Both sides in life sometimes very much blotched with rusty red, sometimes without red.

Here described from a specimen $35 \mathrm{~cm}$. in length from Hakodate.

It is rather common on the shores of Hokkaido. We have examples from Hakodate, Mororan, and the Ainu village of Edomo.

(Named for Dr. Georg Wilhelm Steller, naturalist of Bering's Expedition.)

\section{GLYPTOCEPHALUS Gottsche.}

Glyptocephalus Goтtsche, Archiv für Naturgsch., 1835, p. 156 (type saxicola=cynoglossus Linnæus).

Eyes and color on the right side. Body extremely elongate, more than twice as long as deep, much compressed. Head very small and short, its blind side with many excavations and mucous cavities in the skull, mandible, and preopercle. Mouth very small; teeth moderate, incisor-like, broad, equal, close set, in a single series; no teeth on vomer or palatines. Gill rakers short, weak. Lower pharyngeals narrow, with 1 or 2 rows of conical teeth. Lateral line nearly straight, simple; scales very small, smooth; dorsal and anal very long, there being more than 90 rays in the dorsal and more than 80 in the anal; caudal fin rounded; anal spine present; ventral rays 6 . Vertebræ in increased number, 58 to 65 . Northern seas, in deep water. This genus is one of the most strongly marked in the family, being distinguished from most of the genera by the greatly increased number of vertebræ, and from all of them by the remarkable cavernous structure of the bones of the head. An undescribed species of this genus was seen by us in the museum at Hakodate. Our notes do not, however, justify the publication of the species.

( $\gamma \lambda v \pi \tau o ́ s$, sculptured; $\kappa \varepsilon \phi \alpha \lambda \eta \dot{\text {, head.) }}$ 


\section{Family II. SOLEIDA.}

SOLES.

Body oblong or elongate, usually scaly; mouth very small, much twisted toward the eyed side; the teeth in villiform bands, very small or obsolete; eyes small, close together, with or without a bony ridge between them; edge of preopercle adnate, concealed by the skin and scales; gill openings narrow, the gill membranes adnate to the shoulder girdle above; pectoral fins small or wanting; ventral fins small, one or both sometimes wanting; small fishes, living on sandy bottoms, similar to the Pleuronectidx in structure, but much degraded, the fins and teeth having lost many of their distinctive qualities. The vertebræ are usually in increased numbers. They are numerous in the warm seas, and those of sufficient size are valued as food. In Japan they are collectively known as Usinoshita (cow-tongue). The Soleinæ are quite unlike the Cynoglossinx, and are perhaps independently derived from a flounder ancestry.

KEY TO GENERA.

$a$. Dorsal and anal free from caudal; eyes and color on the right side.

b. Achirine.-Ventral fins unsymmetrical, that of the eyed side extending along ridge of abdomen, more or less united to the anal; vent to the left of median line; lateral line single.

c. Body broad-lanceolate; upper jaw prolonged in a long hook, surrounding lower jaw; scales cycloid; pectoral fins obsolete.............. Amate, 30

$b b$. Soleinæ.-Ventral fins nearly symmetrical, each with short base and free from anal; vent on median line; lateral line single; upper jaw moderately hooked.

$d$. Scales etenoid; rays of dorsal and anal fins scaleless or nearly so; no pectoral

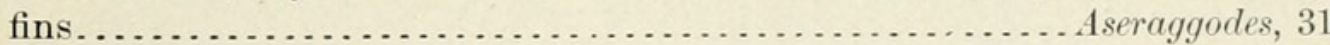

$d d$. Scales cycloid; vertical fins scaleless; no pectoral fins; snout little hooked.

Liachirus, 32

aa. Dorsal and anal joined with the caudal.

e. Synapturniz.-Eyes and color on the right side; ventrals free from anal; body broad.

$f$. Scales ctenoid; left pectoral rudimentary, reduced to a small flap; body with

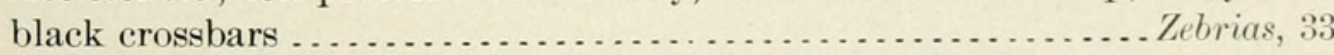

ff. Scales cycloid; pectorals rudimentary; first dorsal ray prolonged; body crossbarred ................................................. 34

ee. Cynoglossine.-Eyes and color on the left side; eyes very small, close together; body lanceolate; no pectoral fins; scales ctenoid.

$g$. Lateral line present, on the left side.

$h$. Lips with tentacles or fringes; blind side without lateral line, a depression taking its place.

$i$. Left side with two lateral lines, right side with one ...... Paraplagusia, 35

ii. Left side with three lateral lines, right side without lateral line.. Usinosita, 36

$h h$. Lips without fringes.

j. Lateral lines, two on the left side, one on the right....... Cynoglossus, 37

$i j$. Lateral lines, three on the left side (two in young), one on the

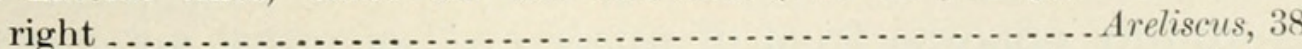

gg. Lateral line wanting; ventral of eyed side only present, free from anal; lips without fringes ................................. Symphurus, 39 
3O. AMATE Jordan and Starks.

Amate Jordan and Starks, new genus (japonicus).

This genus has the form and general proportions of Solea, but with the ventrals unsymmetrical as in Achirus, that of the eyed side having a prolonged base, extending along the ridge of the abdomen, its last ray united by membrane with the anal; vent to the left of the median line of the abdomen; body lanceolate; upper jaw forming a long hook, extending around the lower jaw. Scales ctenoid, vertical fins scaly. Lateral line single. This genus resembles the ordinary Soles, but its relations are with the American genus Achirus.

The type of the genus is the following species, Amate japonica.

(amate, or yamate, a Japanese name of Limanda yokohamæ, from ame, rain; or perhaps ama, a fisherman.)

\section{AMATE JAPONICA (Schlegel).}

Achirus japonicus Schlegel, Fauna Japonica, Poiss., 1846, p. 186 (Nagasaki).

Solea japonica Günther, Cat. Fish, IV, 1862, p. 471 (copied).

Aseraggodes japonicus Jordan and Snyder, Check List, 1901, p. 122 (Misaki).

? Achirus hartzfeldii Bleer er, Amboina, III, p. 123 (Amboyna).

? Solea hartzfeldii Günther, Cat. Fish, IV, 1862, p. 471 (copied).

Aseraggodes hartzfeldii JoRdn and SNyder, Check List, 1901, p. 122.

Habitat. - Sandy bays of southern Japan, also in the East Indies, if Amate hartafeldii is the same species.



Fig, 23.-AMATE JAPONICA.

Head, $3 \frac{4}{5}$ in length to base of caudal; depth, $2 \frac{1}{3}$. Upper eye, 8 in head. Dorsal, 84; anal, 55. Scales from opposite upper end of gill opening to base of caudal, 72; from upper eye to opposite gill opening, 18.

Hook of upper jaw extending around lower jaw usually to a point vertically opposite front of upper eye (somewhat anterior to this in the specimen figured). Fine teeth in bands on blind side of jaws. Middle of upper eye opposite front of lower. Interorbital space flat 
or a little concave; its width equal to the vertical diameter of upper eye. Nostrils of eyed side close together, just in front of lower eye, and ending in tubes; the posterior tube short and broad, the anterior long and slender. Nostrils of blind side farther apart, the posterior one not ending in a tube, the anterior in a wide fleshy tube having a valve at its orifice and broadly fringed around its entire edge with tentacles; blind side of head with tentacles which are much larger toward the ventral edge.

Origin of dorsal on front of head just above tip of hook of upper jaw. Dorsal or anal not joined to caudal; ventral rather broadly united to front of anal; caudal rounded, not angulated at tips of outer rays. Scales everywhere ctenoid; the lateral line extending a short distance on head but not reaching to upper eye.

Color dark slate gray, marked with irregular, indefinite spots, more or less round, or forming obscure broken rings, the largest about twice the diameter of eye and composed of black on the posterior margins of scales in small groups. These are arranged more or less definitely; 3 or 4 on lateral line and several along body near base of dorsal and anal fins. The latter in small specimens interspaced with small white spots, slightly out of line with the black ones, and nearer the base of the fins. Other smaller spots are scattered over the head and body, and some specimens show slight traces of light vermiculations. All of the fins thickly spotted with small irregular spots of various sizes in sharp contrast with the nearly colorless surrounding areas.

Here described from specimens from Wakanoura, the largest 135 $\mathrm{mm}$. in length. Other specimens from Tokyo, Tsuruga, Misaki, Kobe, and Nagasaki. It is common in sandy bays of southern Japan.

(japonicus, Japanese.)

\section{ASERAGGODES Kaup.}

Aseraggodes a KauP, Wiegmann's Archiv., 1858, p. 103 (guttalatus).

This genus is allied to Solea and other genera of European soles, differing from all these in the entire absence of pectoral fins. The ventral fins are nearly symmetrical, that of the eyed side being free from the anal. Vent nearly on the median line of abdomen. Scales ctenoid; eyes and color on the right side; dorsal and anal free from caudal. Small fragile soles of the East Indian region, the fin rays fewer, the snout less hooked than in the genus Amate. Rays of dorsal and anal scaleless or nearly so.

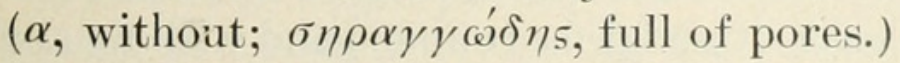

$a$ This genus is thus defined by Kaup: "Achiren ohne Poren au den verticalen Flossen. Caudal rund und bestimmt getrennt. Mehr oblonger form." (Guttulatus, poropterus, and hartzfeldi.) 


\section{ASERAGGODES KOBENSIS (Steindachner).}

Solea (Achirus) kobensis Steindachner, Reise Aurora, 1896, p. 218 (Kobe).

Aseraggodes kobensis JoRDAN and SNYDER, Check List, 1901, p. 122.

Habitat.-Sandy shores of southern Japan.

Head, $4 \frac{1}{2}$ to base of caudal; depth, $2 \frac{2}{5}$. Eye, 6 in head; snout (to upper eye), $3 \frac{1}{3}$; depth of caudal peduncle, 2 . Dorsal, 70; anal, 51. Scales, counting from opposite gill opening to caudal, 61; from opposite upper eye, 76 ; in a transverse oblique series near middle of body, $24+1+26$.

Snout but little hooked; the tip of the hook slightly in advance of tip of the mandible and on a level with lower margin of lower eye. Gape ending opposite front of pupil of lower eye. Fine teeth in rather broad bands on blind side of jaws, 3 or 4 teeth in a single row on front of premaxillary of eyed side. Interorbital space concave; its width equal to length of pupil. Middle of upper eye directly over

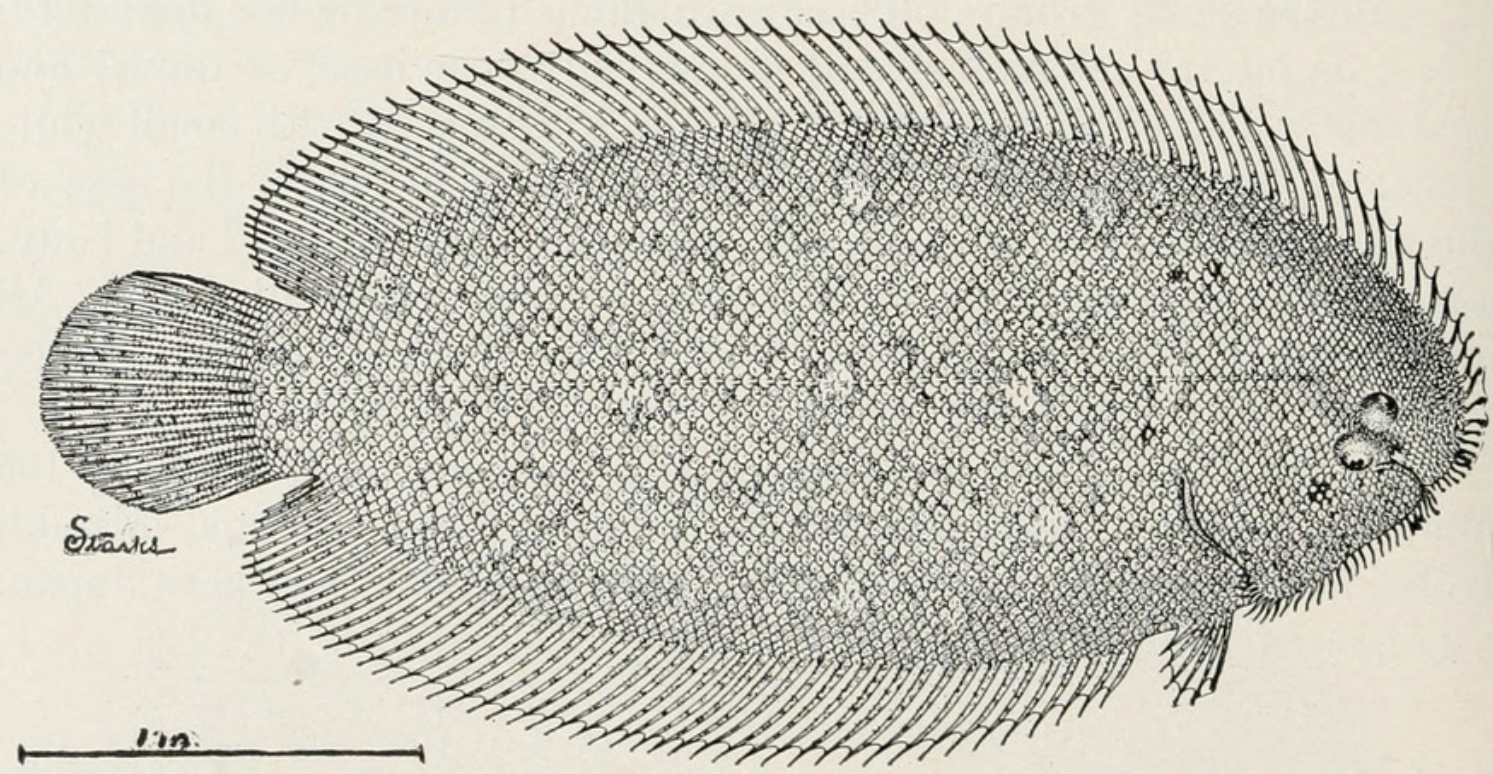

Fig. 24.-AsEraggodes KoBENSIS.

front of lower eye. Anterior nostril of colored side ending in a wide tube above the middle and close to the edge of mouth; that of blind side higher, the tube slightly longer. Posterior nostril of eyed side under front of lower eye and with a thin flap at its anterior margin. Length of gill opening 2 in head.

Origin of dorsal on front of head on a level with middle of upper eye. Longest dorsal rays equal to length of longest anal rays and contained $1 \frac{5}{6}$ in head. Ventral of eyed side not joined to anal, its tip just reaching to first anal ray. Caudal fin rounded and with no angles at tips of outer rays; its length one diameter of eye shorter than head. Lateral line straight and simple, extending a short distance on head, but not reaching to upper eye. Scales everywhere ctenoid except on anterior part of blind side of head.

Color grayish brown, with 3 or 4 irregular and indefinite dark spots or sometimes rings on lateral line. Small dark points scattered over 
the body, with slightly larger ones spaced near the base of dorsal and anal fins and interspaced with bluish white spots. Many specimens from Nagasaki from 7 to $9 \mathrm{~cm}$. in length. It is rather common in sandy bays of southern Japan.

(Kobensis, from Kobe.)

\section{LIACHIRUS Günther.}

Liachirus GüNTher, Cat. Fish, IV, 1862, p. 479 (nitidus).

Eyes and color on the right side, mouth narrow, more developed on the blind side; teeth minute, on the blind side only. Dorsal and anal rays scaleless, without pores at base; dorsal beginning on the snout; caudal free from dorsal and anal; no pectorals; ventrals both developed, free from anal. Scales small, cycloid. Lateral line straight; an accessory lateral line on blind side, from snout along upper profile of nape. Gill openings narrow, the membranes broadly united. One species known, differing from Aseraggodes mainly in the cycloid scales.

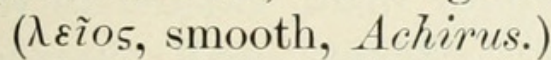

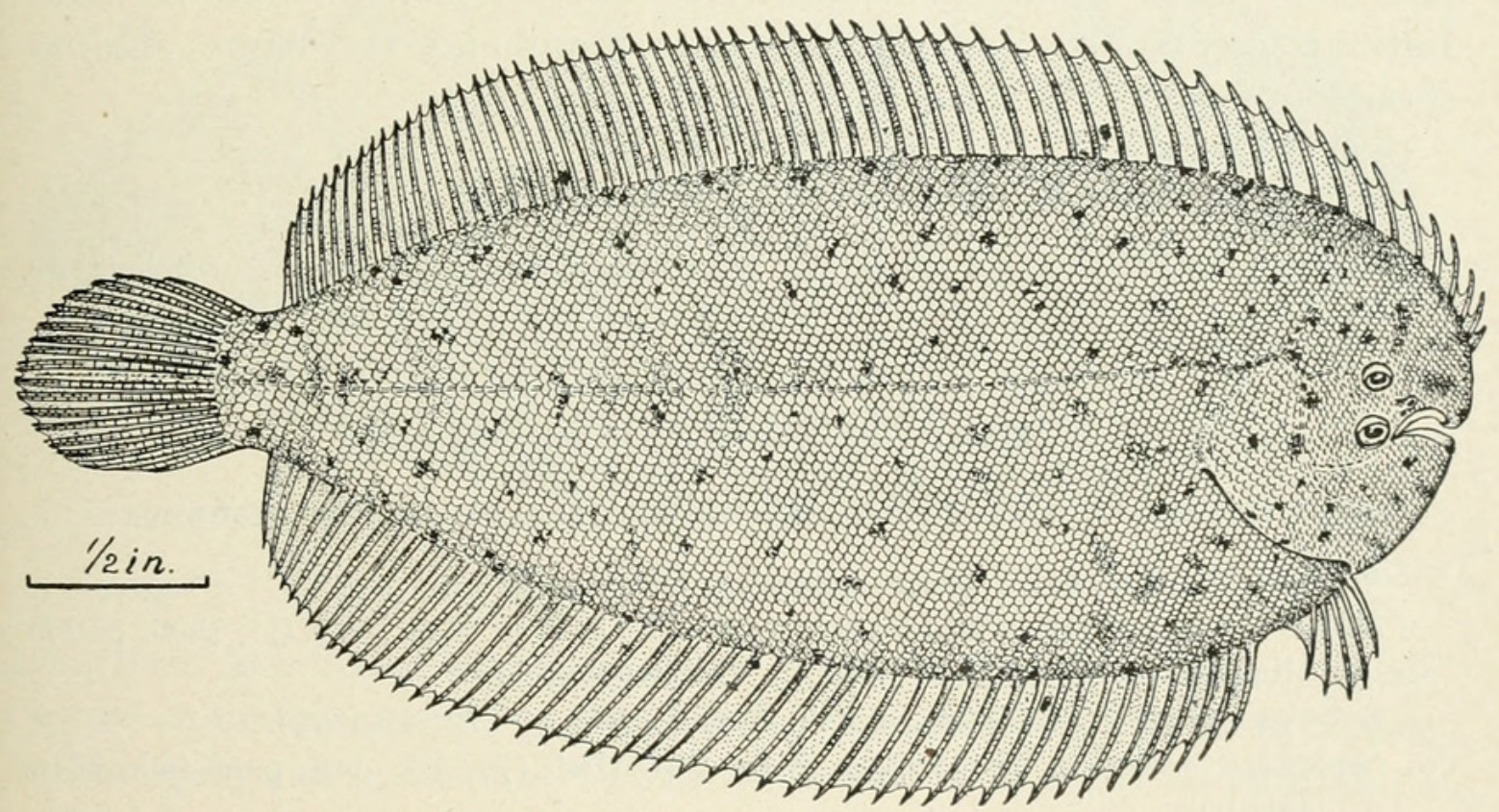

Fig. 25.-LiACHIRUS NITIDUS.

48. LIACHIRUS NITIDUS Günther.

Liachirus nitidus Günther, Cat. Fish, IV, 1862, p. 479 (China).-Jordan and Evermann, Proc. U. S. Nat. Mus., XXV, 1902, p. 366 (Giran, Formosa).

Habitat.-Coast of China, north to Formosa and Kiusiu.

Head, $4 \frac{1}{2}$ in length to base of caudal; depth, $2 \frac{1}{2}$. Snout, $3 \frac{1}{5}$ in head. Dorsal, 63; anal, 48; ventral, 5. Scales, 25-92-35. Body dextral, oblong elliptical; snout bluntly rounded. Mouth rather large, the gape reaching eyes. Eyes close together, small. Scales very small, smooth and rather loosely attached; lateral line extending from near upper eye nearly straight to middle of caudal. Dorsal and anal fins rather high, the longest rays $1 \frac{4}{5}$ in head. 
Color yellowish gray, the body and head sparsely covered with small, roundish, black spots, a few of these upon dorsal and anal fins. Dorsal and anal rays black edged; caudal with a few dark specks.

One specimen was taken by Dr. Hugh M. Smith at Suzaki in Shikoku, province of Tosa, and at Yamagawa, in Kagoshima Bay, the above account from a specimen 4 inches long from Giran, Formosa

(nitidus, shining.)

\section{ZEBRIAS Jordan and Snyder.}

Asopia KAup, Weigmanns Archiv., 1858, p. 95 (zebra, cornuta, etc.).

Zebrias Jordan and Snyder, Proc. U. S. Nat. Mus., XXIII, 1900, p. 380 (zebrinus).

Allied to Synaptura, differing in having the pectoral fin of the left side rudimentary or wanting. Body with black cross bars, more or less arranged in pairs. Body broad-ovate; dorsal and anal united with the caudal. Eyes and color on the right side. Eyes rather small, the upper in advance of lower. Mouth small, twisted to the left side; teeth minute, on blind side only. Scales small, ctenoid. Lateral line single, straight. In our judgment, the name Esopia should replace Zebrias, for this genus.

(zebra, zebra.)

KEY TO SPECIES.

a. Caudal with yellow spots; dorsal and anal fully united to caudal..... zebrinus, 49 aa. Caudal without yellow spots; dorsal and anal not fully united to caudal ................................................. 50

\section{ZEBRIAS ZEBRINUS (Schlegel).}

SHIMA-USINOSHITA (STRIPED COW-TONGUE); SHIMAGAREI (STRIPED FLOUNDER).

Solea zebrina Schleger, Fauna Japonica, 1846; p. 186, pl. xcv, fig. 1 (Nagasaki). Zebrias zebrinus Jordan and Snyder, Proc. U. S. Nat. Mus., XXIII, 1900, p. 900

(Nagasaki); Check List, 1901, p. 123 (Nagasaki).

Solea ommatura Richardson, Ichth. China, 1846, p. 279 (Canton).

Synaptura ommatura REgAN, Ann. Mag. Nat. Hist. (7), XI, 1903, p. 56 (southern Japan).

Pleuronectes fasciatus Gronow, Syst., Ed. Gray, 1854, p. 91.

Synaptura zebra Günther, Cat. Fish, IV, 1862, p. 484 (Amoy, Pinang).-NAmiye, Class. Cat., 1881, p. 111 (Tokyo).-Oтакі, Journ. Fish. Bur., 1897, p. 8, pl. viin, fig. 11.--Ishikawa, Prel. Cat., 1897, p. 24 (Tokyo).

Brachirus zebra Bleek er, Atlas Pleur., 1870, pl. Ix, fig. 3 (East Indies); Poiss. Conn. Japoni, 1870, p. 22 (Nagasaki, Shimoda).

(Not Pleuronectes zebra Bloch, Ausl. Fische, III, 1790, p. 27, pl. CLXXXviI= Synaptura zebra $\mathrm{DAY}_{\mathrm{A}}$, Fishes India=Aesopia quagga KAUP, Wieg. Archiv., 1858, p. 98.)

Zebrias zebra Jordan and Snyder, Proc. U. S. Nat. Mus., XXIII, 1901, p. 769

(Yokohama).-Jordan and Evermann, Proc. U. S. Nat. Mus., XXV, 1902, p. 367 (Formosa, not of BLOCH).

Habitat. - Coasts of Japan, north to Hakodate, south to Formosa. 
Head, $5 \frac{1}{2}$ to $5 \frac{3}{4}$ in length to base of caudal; depth, $2 \frac{1}{2}$ to $2 \frac{2}{3}$. Upper eye, $6 \frac{1}{2}$ to $7 \frac{1}{2}$ in head. Dorsal, 72 to 76 ; anal, 63 to 66 . Scales from opposite gill opening to caudal, 89 to $96 ; 15$ or 16 on head between upper eye and gill opening.

Mouth terminal and curved, but the tip of upper jaw scarcely hooked. Small teeth in bands on blind side of jaws. Eyes separated by a narrow, scaly interorbital space, less than half the diameter of upper eye. Anterior fourth to two-fifths of upper eye above front of lower eye.

Upper 3 or 4 rays of pectoral of eyed side produced but not abruptly, the lower outline concave and the length of the rays from the first to the last graduated, its length of the produced rays variable, from $1 \frac{1}{4}$ to $2 \frac{1}{4}$ in head. Ventrals nearly symmetrical and well separated from the anal. Last rays of dorsal and anal reaching to tips of caudal rays, so that the outline is continuous around the caudal.

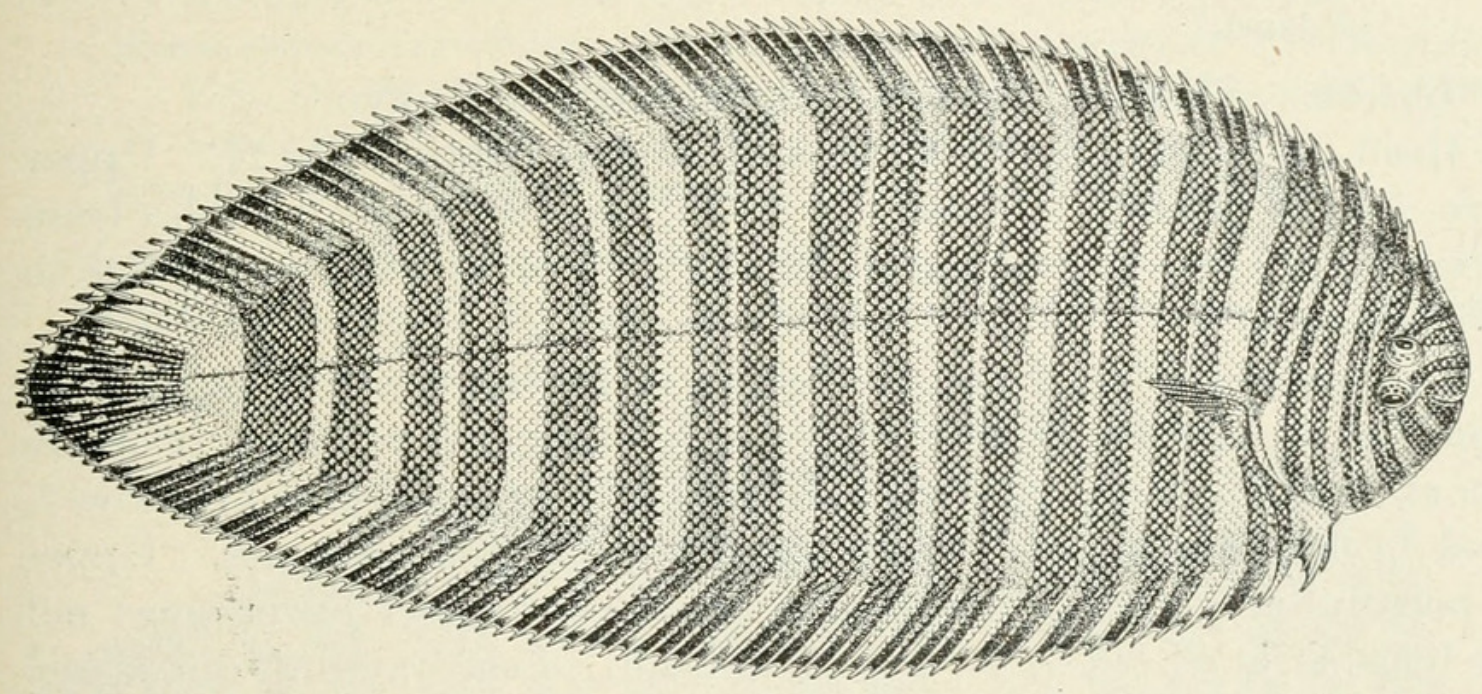

Fig. 26.-ZEBRIAS ZEBRINUS.

Length of last dorsal ray $1 \frac{1}{2}$ in head, equal in length to that of anal. Caudal rounded narrowly; its length nine-tenths of that of head. Scales everywhere ctenoid. Pores of lateral line equal in number to series of scales; the lateral line extends onto the head over 6 or 7 scales.

Head and body light gray crossed with black bars more or less definitely arranged in pairs. These may be uniform black or a little lighter in the middle, but never conspicuously lighter as in Z. japonicus. A bar across gill opening, involving base of pectoral, its posterior edge just behind base of pectoral. Behind this are 8 pairs of bars, the posterior one of the last pair much the widest, its posterior edge just at or somewhat anterior to base of caudal. Base of caudal rays of the gray body color; the greater part of the caudal, including the tips of the dorsal and anal rays, marked with a large round dead black spot two-thirds of the length of the head in diameter and bearing several milk-white, clear-cut oblong spots of irregular size, often 
arranged as an obscure ring. Two small specimens have the white spots fewer, larger, and not so sharp cut. The bars of the body extend to the edges of the dorsal and anal fins, running longitudinally with the rays. Posteriorly the dorsal, anal, and caudal are narrowly edged with white. Vertical fins of the blind side uniform black, edged with white, growing light toward base of rays. Pectoral black.

Many specimens from 12 to $24 \mathrm{~cm}$. in length collected at Nagasaki, Tokyo, Kobe, and Hakata. The species is common in southern Japan, where it reaches a considerable size. It is valued as a food fish.

(zebrinus, zebra-like.)

\section{ZEBRIAS JAPONICUS (Bleeker).}

Esopia japonica Bleek er, Japan, VI, 1869, p. 71 (Nagasaki; (young). Synaptura japonica GüNther, Cat. Fish, IV, 1862, p. 485 (copied.)

Brachirus japonicus Bleeker, Enum. Poiss., Conn. Jap., 1879, p. 22 (Nagasaki). Synaptura smithi Regan, Ann. Mag. Nat. Hist., 1903, p. 57, pl. vi (Inland Sea of Japan).

Habitat.-Shores of southern Japan, north to Tokyo.

Head, $5 \frac{1}{2}$ to $5 \frac{3}{4}$ in length to base of caudal; depth, $2 \frac{1}{2}$ to $2 \frac{3}{4}$. Upper eye, 5 to $5 \frac{1}{2}$ in head. Dorsal, 73 to 79 ; anal, 59 to 64 . Scales from opposite gill opening to caudal, 80 to 98 ; 15 or 16 from upper eye to gill opening.

This species differs from $Z$. zebrinus in having the eyes larger. In some specimens the upper eye is scarcely in advance of lower, in others the anterior third of upper eye overhangs the front margin of the lower, and in others the upper eye varies between these extremes. Upper 2 pectoral rays abruptly produced beyond the short lower ones; not so long as in $Z$. zebrinus, 2 to $2 \frac{1}{2}$ in head. Last rays of dorsal and anal attached to base of caudal, leaving the latter distinct and the outline of fins not continuous around caudal, as in Z. zebrinus. The papillæe on the blind side of head are much more numerous.

The cross bars on body not so dark or not so uniform in color as in Z. zebrinus; the middle of each bar always much lighter than the edges, often so light as to subdivide some of the bars. A light interspace is across the gill opening, and instead of the posterior edge of a dark bar being just behind the pectoral as in $Z$. zebrinus, the anterior edge of a bar is in this place. Behind the pectoral are 8 or 9 pairs of dark bars, the last bar crossing the base of the caudal, about half of it being on the caudal rays; behind this is a gray or white bar, and the posterior third of the fin is abruptly black. Pectoral light or dusky. 'The species otherwise as $Z$. zebrinus. The attachment of the dorsal and anal to the caudal is not variable in our specimens as described by Regan.

Specimens from Tokyo and Wakanoura, from 100 to $165 \mathrm{~mm}$. in length. Southern Japan, rather rare.

(japonicus, Japanese.) 


\section{ESOPIA Kaup.}

Asopia KaUp, Wiegmanns Archiv., 1858, p. 95. (Cornuta, as restricted by GÜNTHER, Cat. Fish, IV, p. 487.)

Scales cycloid, smooth; first dorsal ray prolonged; pectorals rudimentary. Otherwise as in Zebrias. As originally constructed, Esopia was equivalent to Zebrias, but $E$. cornuta was included among the species, originally renumerated by Kaup, and the name Esopia was restricted to that species by Günther. Nevertheless we think that the name Esopia should be used for the genus here called Zebrias. In that case, cornuta should receive a new generic name.

( Asop, the author of classic fables, in allusion to the slave costume of many stripes, worn by Esop, and by these fishes.)

\section{I. ÆSOPIA CORNUTA Kaup.}

Jerree potoo Russell, Fish Coromandel, 1803, pl. LXXII (Vizagapatam, "La Sole Cornue"). - Cuviér, Règne Animal, 2 d ed., 1828; after Russell.

Esopia cornuta KAUP, Wiegm. Archiv., 1858, p. 95 (British India).—Günther, Cat.

Fish, IV, 1862, p. 487 (copied).—DAY, Proc. Zool. Soc., 1873, p. 238 (India);

Fishes India, p. 438, pl. xcrv, fig. 4 (Coromandel).

Synaptura potoo Bleek ER, Bengal en Hindustan, p. 76, after Russell.

Habitat.-India, north to Nagasaki.

Head, $4 \frac{3}{4}$ in length to base of caudal; depth, 3. Eye, $5 \frac{1}{2}$ in head.

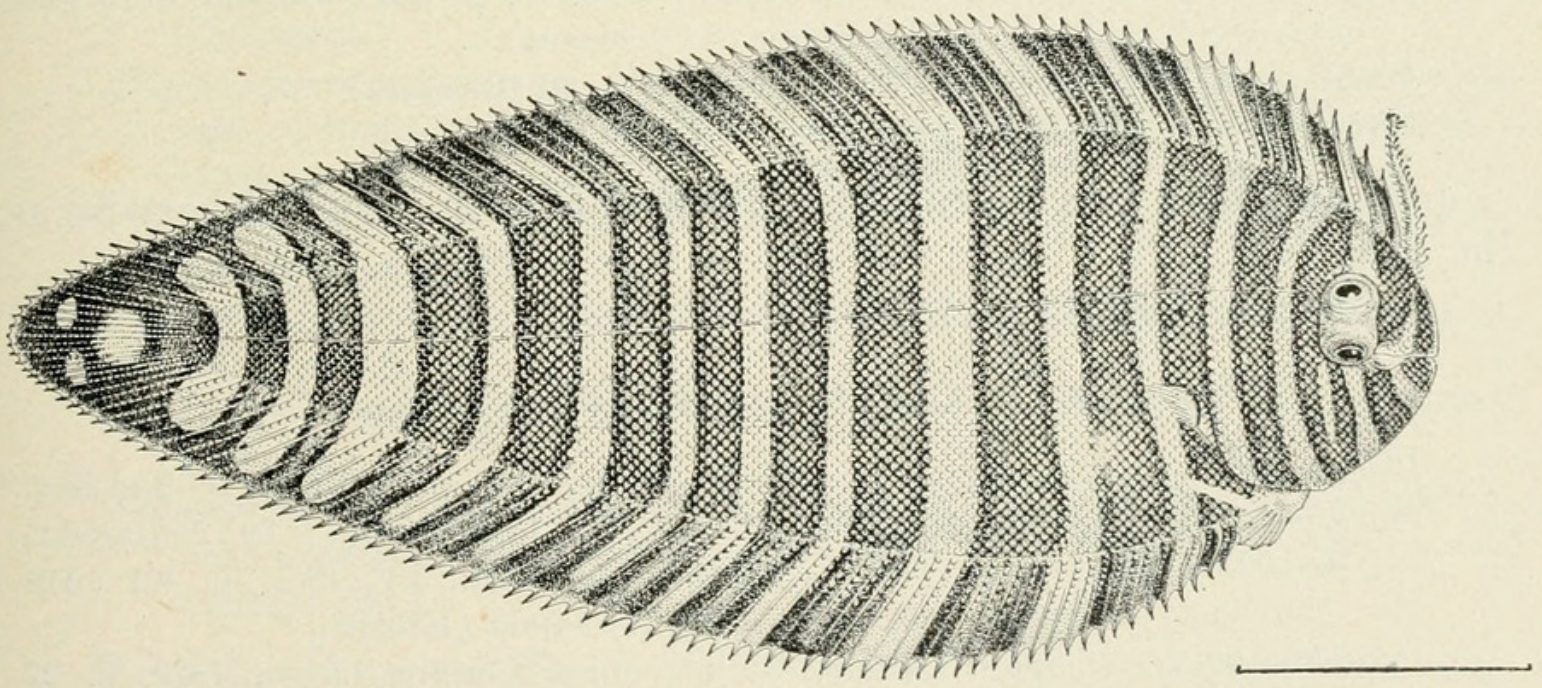

Fig. 27.-ASOPIA CORNUTA

Dorsal 79; anal, 66 . Scales from opposite gill opening to caudal, 94; from upper eye to gill opening, 19.

Jaws even in front, the gape extending back to below front edge of pupil of lower eye. Teeth very small, in bands on blind side of jaws. Eye contiguous, the upper very slightly in advance of lower. Anterior nostril of colored side in a large tube, much longer and wider than its mate of the opposite side.

First ray of dorsal swollen, produced, and covered with small tentacles or villæ. It is situated vertically above anterior nostril and its 
length is contained $1 \frac{1}{3}$ times in head. The dorsal and anal are attached to the entire length of the outer caudal rays, so that the outline around them is unbroken. Ventrals symmetrical and well separated from anal. Pectorals of both sides rudimentary, represented by a short flap broader than long in which the rays are evident. Lateral line straight, continued on head over 11 or 12 scales, not reaching to upper eye. Scales everywhere cycloid.

Color grayish brown crossed with wide, dark-brown bands, rather lighter in the middle, and extending to the tips of the dorsal and anal rays. Four bands on head, the one at posterior part of eye divided into 2 ; one across rudimentary pectoral and gill opening, behind which are 11 bands, counting a small spot at base of caudal rays; caudal and distal half of posterior dorsal and anal rays black; a round opaque white spot at middle of caudal. Dorsal and anal rays opposite the light bars on body are opaque white and sometimes a suggestion of the same color opposite the middle of the dark bars. Dorsal, anal, and caudal uniform dark on blind side growing light toward base.

Here described from a single specimen $125 \mathrm{~mm}$. long from Nagasaki. It has not otherwise been recorded except from India.

(cornutus, horned.)

\section{PARAPLAGUSIA Bleeker.}

Plagusia (Brown) Cuviér, Regne Animal, II, 1817, p. 224 (bilineata, etc.) (not Plagusia Latreille, 1806, a genus of Crustacea).

Paraplagusia Bleeker, Atlas Pleuron., 1870, p. 26 (bilineata).

? Rhinaplagusia Bleek er, Atlas Pleuron., 1870, p. 26.

Left side with two lateral lines, right side with one. Otherwise as in Usinosita.

( $\pi \alpha \rho \alpha$, near; Plagusia.)

\section{PARAPLAGUSIA DIPTERYGIA (Rüppell).}

Plagusia dipterygia Rüppell, Atlas Fische, 1828, p. 123, pl. xxxı, fig. 3 (Red Sea). Plagusia marmorata Bleek er, Verh. Bat. Gen., XXIV, Pleuron, p. 20 (Amboyna);

Nederl. Tydsch, I, p. 411.-Günther, Cat. Fish, IV, 1862, p. 491 (Amboyna).-Bleeker, Enum. Poiss. Conn. Japon (Kiusiu).

Paraplagusia marmorata Bleeker, Enum. Poiss. Connus Japon, 1879, p. 22. (No locality specified, probably Riu Kiu Islands).

Habitat. - East Indies, doubtfully recorded from Japan.

Head, two-ninths of total length; depth, over one-fourth. Dorsal, 99 to 106 ; anal, 75 to 85 . Lateral line, 100.

Two lateral lines on left side separated by 17 longitudinal series of scales at the point of their greatest distance. Length of snout two-fifths of that of head. Rostral hook very long, extending far behind lower eye. Color brownish finely marbled with dark brown. (Günther.)

Not seen by us.

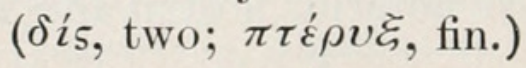


36. USINOSITA Jordan and Snyder.

Usinostia Jordan and Snyder, Proc. U. S. Nat. Mus., XXIII, 1900, p. 380. (japonica.)

Usinosta Jordan and SNyder, Check List, 1901, p. 123. (japonica.) (Usinostia and Usinosta both accidental misprints for Usinosita.)

Usinosita Jordan and Evermann, Proc. U. S. Nat. Mus., XXV, 1902, p. 366. (japonica.)

Eyes and color on the left side; no pectoral fins; dorsal and anal united around the tail; ventral of the blind side absent, that of eyed side so connected to anal as to be scarcely distinguished from it; scales ctenoid, small; lateral lines 3 on the left side, a rudimentary one on the right without pores; upper jaw ending in a hook, surrounding the lower jaw; lip of colored side with tentacles; teeth minute on blind side only. One nostril, on the left side, before angle of lower orbit. Gill opening very narrow; body lanceolate.

(usinoshita, the Japanese name; usi, cow; shita, tongue in Japanese; no, is the mark of the genitive case.)

\section{USINOSITA JAPONICA (Schlegel).}

USINOSHITA (COW-TONGUE); SHITA-BIRAME (TONGUE-FLOUNDER); AOSHITABIRAME (BLUE TONGUE-FISH).

?? Pleuronectes japonicus a Houtruyn, Holl. Mats. Weet. Haarlem, 1782, p. 311 (Nagasaki.)

Plagusia japonica Schlegel, Fauna Jap. Poiss., 1846, p. 187, pl. xcv, fig. 2 (Nagasaki).-Bleeker, Act. Soc. Sci. Ind. Nederl. Japan, IV, p. 26 (Nagasaki). Günther, Cat. Fish, IV, 1862, p. 492 (copied.)-Namiye, Class. Cat.,1881, p. 111 (Tokyo).-Отакі, Journ. Fish. Bur., 1896, p. 8.-Ishiкawa, Prel. Cat., 1896, p. 24 (Tokyo).

Usinostia japonica Jordan and Snyder, Proc. U. S. Nat. Mus., XXIII, 1900, p. 380 (Tokyo).

Usinosta japonica JoRDAn and SNyder, Check List, 1901, p. 123 (Nagasaki, Shimoda).

Usinosita japonica Jordan and Evermann, Proc. U. S. Nat. Mus., XXV, 1902, p. 366 (Keerun).-Jordan and Starks, Bull. U. S. Fish Com., 1904, p. 628 (Suruga Bay).

Habitat. - Coasts of Japan and Formosa, north to Aomori.

Head, $4 \frac{1}{3}$ to $4 \frac{1}{2}$ in length to base of caudal; depth, $3 \frac{1}{4}$ to $3 \frac{1}{2}$. Eye, 12 to 14 in head; interorbital space, 13 to 14 ; distance from front of head longitudinally to upper eye, $2 \frac{1}{3}$. Dorsal, 104 to 110 ; anal, 83 to 86 . Scales, from opposite gill opening, 92 to 96.

Hook of upper jaw very long, extending around lower jaw to opposite vertical from posterior margin of lower eye, or often considerably

$a$ Form of the European sole. Eyes on the left side. P. 9; V. 5; C. 16. Dorsal and anal rays not counted, for the large numbers. Body 6 inches long, somewhat round on the dorsal side, white below. (Houttuyn.) The enumeration of pectoral rays prevents us from identifying Houttuyn's description with this species. The only soles in Japan with pectoral fins have the eyes on the right side. 
past. Teeth in bands on blind side of jaws. Lips of eyed side with long, fringed tentacles, larger on lower lip; anterior nostrils in tubes. Interorbital space flat or slightly concave, covered with scales, in large specimens $\left(28 \mathrm{~cm}\right.$. long) $1 \frac{1}{3}$ times long diameter of upper eye; equal to diameter of eye in smaller specimens $(20 \mathrm{~cm}$. long). Relative position of eyes somewhat variable, in some specimens the anterior two-thirds of upper eye is in front of the vertical from anterior edge of lower eye, in others the upper eye varies from this point until its posterior edge is vertical from anterior edge of lower eye.

Outline of dorsal, anal, and caudal continuous around tail, the caudal not differentiated by a notch at last rays of dorsal and anal. Ventral 4 rayed, and scarcely differentiated from anal; ventral of blind side absent. Scales ctenoid on eyed side, cycloid on blind side. A slight depression on blind side along middle of body suggests a lateral line but it is without pores; 3 lines on blind side of body, one median, and one following each the dorsal and anal outline of body.

Color uniform brown usually with irregular dark specks scattered irregularly and sparsely over the body; fins uniform darker brown with pale margins, similar but darker on blind side.

Here described from specimens from 20 to $28 \mathrm{~cm}$. in length from Wakanoura, Kobe, and Tokyo. It is a common market fish of south ern Japan.

(japonicus, Japanese.)

\section{CYNOGLOSSUS Buchanan-Hamilton.}

Cynoglossus Buchanan-Hanilton, Fishes of the Ganges, 1822, p. 32 . (lingua.)

Body lanceolate, covered with ctenoid scales; two lateral lines on the left side, one rudimentary on the right as in Usinosita; Eyes and color on the left side; snout produced into a hook; mouth narrow, the lips not fringed; two nostrils on the left side, one of them between the eyes. Gill opening very narrow.

East Indian Seas: The genus is here restricted by the separation of the species with two lateral lines on each side (Arelia), of those with three lateral lines (Areliscus), of those with peculiar nostrils (Cantoria), of those with one nostril (Trulla), and of those with none (Icania).

( $\kappa \dot{v} \omega \nu, \operatorname{dog} ; \gamma \lambda \omega \tilde{\sigma} \sigma \alpha \alpha$, tongue.)

KEY TO SPECIES,

x. Eye about 12 in head. D. 125 , A. 98 . Scales about 70 ; about 10 series of scales between lateral lines . . . . . . . . . . . . . . . . . . . . . . . . robustus, 54 aa. Eye $7 \frac{1}{2}$ in head. D. 129, A. 104 . Scales 74 . Nine rows of scales between lateral

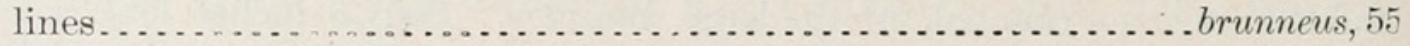




\section{CYNOGLOSSUS ROBUSTUS Günther.}

Cynoglossus robustus Günther, Ann. Mag. Nat. Hist., 1873, p. 243 (Shanghai). (D. 130. Scales 83.) —Steindachner, Reise Aurora, 1896, p. 219 (Kobe).Jordan and Snyder, Check List, 1901, p. 123.

Habitat. - Coasts of Japan and North China, north to Tokyo.

Head, from $4 \frac{3}{4}$ to 5 to base of caudal; depth, $3 \frac{8}{4}$ to $3 \frac{4}{5}$. Upper, eye, $12 \frac{1}{2}$ to $13 \frac{1}{2}$ in head. Dorsal, 122 to 127 ; anal, 96 to 100 . Scales from opposite gill opening, 69 to 71 .

Upper jaw moderately hooked, the point of hook reaching to below anterior nostril, or a little anterior to this point. Lips not fringed; fine teeth in bands on blind side of both jaws. Anterior nostril of eyed side in a tube, the posterior nostril wider, without a tube, its position on interorbital space just behind front of eyes. Both nostrils of blind side in short tubes, the posterior are much the wider. Upper eye slightly in advance of lower; interorbital space slightly concave, covered with scales, its width equal to vertical diameter of upper eye.

Ventral 4 rayed, broadly joined to the anal; its rays closer together than the anal rays, and its distance from anal somewhat greater than distance between anal rays. Outline of dorsal and anal unbroken around caudal. Scales ctenoid on posterior part of eyed side of body; cycloid on anterior part and on blind side. Ten scales between lateral lines at middle of body; 76 to 79 longitudinal series of scales, counting from the line of pores connecting upper and lower lateral lines (as counted by Steindachner).

Color uniform light brown; the fins darker brown, growing light at edges; fins on blind side colorless.

We have specimens of this species from Tokyo, Kobe, Onomichi, and Nagasaki; the largest $36 \mathrm{~cm}$. in length.

It is the largest and most abundant of the Tongue-fishes in Japan, next to Usinosita japonica. It is valued as a food-fish. It is somewhat doubtful whether the Japanese species is indentical with the Chinese form called robustus.

(robustus, strong.)

\section{CYNOGLOSSUS BRUNNEUS Regan.}

Cynoglossus brunneus Regan, Ann. Mag. Nat. Hist., 1905, p. 26 (Inland Sea of Japan).

Habitat.-Coasts of southern Japan.

Head, $4 \frac{2}{3}$ in length; depth, 4 . Eye, $7 \frac{1}{2}$ in head; snout, $2 \frac{3}{5}$. Dorsal, 129; anal, 104; scales, 74 .

Interorbital width 3 times in eye. Two nostrils on eyed side, one between anterior parts of eyes, the other in front of lower eye. Maxillary extending to below posterior mergin of eye; rostral hook extending to below mandibulary syinphysis, Two lateral lines on

Proc. N. M. vol. $\mathrm{xxxi-06-16}$ 
eyed side with 9 rows of scales between them. Color, uniform brownish. Length $200 \mathrm{~mm}$. (Regan.) Inland Sea of Japan.

This species differs from Cynoglossus robustus particularly in having a larger eye. We have seen no specimens.

(brunneus, brown.)

\section{ARELISCUS Jordan and Snyder.}

Areliscus Jordan and Snyder, Proc. U. S. Nat. Mus., XXIII, 1900, p. 380. (joyneri.)

This genus differs from Cynoglossus in the presence of three lateral lines on the left or eyed side of the body. The third or lowest of these is often obsolete in the young. The genus is therefore little different from Cynoglossus.

(Arel, an Indian name of Aretia arel.)

KEY TO SPECIES.

a. Scales moderate, less than 100 in lateral line.

b. Dorsal rays, 104; anal, 83 ; scales 70 . Eye, 7 in head; lower lateral line obsolete in young, the upper more or less interrupted ........... interruptus, 56

$b b$. Dorsal rays, 110 ; anal, 85 ; scales, 75 . Eye, 15 in head; lower lateral line well

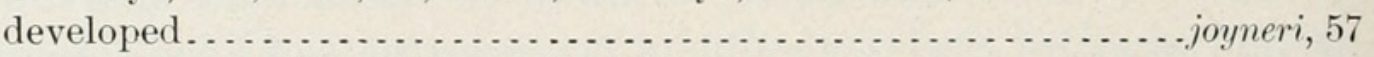

aa. Scales, very small, 120 to 150 in lateral line.

c. Dorsal rays, 128; anal, 104; scales, 120 . Eye, 8 in head...purpureomaculatus, 58 cc. Dorsal rays, 123; anal rays, 95; scales, 145 . Eyes very small.....semilxvis, 59

\section{ARELISCUS INTERRUPTUS (Günther).}

GENCHO (ORIGINAL ONE).

Cynoglossus interruptus Günther, Shore Fishes Challenger, 1880, p. 70, pl. xxx, fig. B (Yokohama, Swatow).--Sterndachner, Reise Aurora, 1896, p. 220 (Kobe, Hiogo, Nagasaki).— Отакі, Journ. Fish. Bur., 1897, p. 8.-Jordan and Snyder, Proc. U. S. Nat. Mus., XXIII, 1900, p. 380 (Tokyo); Check List, 1901, p. 123 (Yokohama).

Head, $5 \frac{1}{5}$ to $5 \frac{1}{3}$ in length to base of caudal; depth, $3 \frac{1}{2}$ to $3 \frac{3}{4}$. Upper eye, 7 to $7 \frac{1}{2}$ in head. Dorsal, 102 to 106 ; anal, 80 to 85 . Scales from opposite gill opening to caudal base 65 to 70 ; from upper posterior edge of opercle 5 or 6 more.

Eyes very close together, but with an evident septum; anterior edge of pupil opposite anterior edge of lower eye. End of maxillary under posterior edge of pupil of lower eye. Anterior nostril in a tube in front of lower eye; posterior nostril rather small, without a tube and placed between front of eyes.

Ventral joined to anal. Scales everywhere ctenoid except on anterior part of blind side of head. Three lateral lines usually present, the upper and lower ones not so well developed as in the genus Usinosita. Frequently the lower one is broken at irregular intervals, and often, especially in the smaller examples, it is entirely absent, in 
which case the upper one is confined to the anterior part of the body as described by Günther for the type.

Head and body uniform dusky brown; the fins darker and slightly mottled, growing lighter toward the tips of the rays; fins dusky on blind side.

Of this species we have specimens from Tokyo, Nagasaki, Wakanoura, Matsushima, Onomichi, and Hiroshima. The largest $17 \mathrm{~cm}$. in length.

It is generally common in the markets of Japan, reaching a smaller size than Cynoglossus robustus.

(interruptus, interrupted, in allusion to the broken upper lateral line.)

\section{ARELISCUS JOYNERI (Güther).}

Cynoglossus joyneri Günther, Ann. Mag. Nat. Hist., 1878, p. 486 (Tokyo); Shore Fish Challenger, p. 70, pl. xxx, fig. a (Tokyo).-OTAKI, Journ. Fish. Bur., 1896, p. 9, pl. vпI, fig. 12 .

Areliscus joyneri Jordan and Snyder, Proc. U. S. Nat. Mus., XXIII, 1900, p. 380 (Tokyo); Check List, 1901, p. 123 (Yokohama).

Habitat.-Coasts of Southern Japan, north to Tokyo.

Head, $4 \frac{2}{3}$ to $4 \frac{4}{5}$ in length to base of caudal; depth, $3 \frac{3}{5}$ to $3 \frac{4}{5}$. Eye, 15 or 16 in head. Dorsal, 106 to 112 ; anal, 83 to 86 . Scales, from opposite gill opening, 70 to 75 ; from upper end of opercle, 5 or 6 more.

Eyes small, separated by a flat or slightly concave space, covered with scales, and equal in width to vertical diameter of eye; middle of upper eye over front margin of lower. Rostral hook reaching around mandible to a point vertical from front of upper eye or sometimes a little anterior to that point. Lips not fringed; teeth rather coarse, in bands on blind side of jaws. Anterior nostril of eyed side in a tube, in front of, and on a level with lower edge of lower eye; posterior nostril ending at surface of skin between front of eyes opposite middle of interorbital space.

Ventral connected with anal by membrane. Scales everywhere cycloid on eyed side except posteriorly where a few scales are ctenoid, the spinules rather few on each scales, some scales with only one. Lateral lines three, separated at the middle of body by 12 series of scales.

Color uniform brownish, the fins darker, but growing white at the edges; fins on blind side colorless.

Of this species we have several specimens from Tokyo, the largest $225 \mathrm{~mm}$. long.

(Named for Mr. Joyner, its discoverer.) 
58. ARELISCUS PURPUREOMACULATUS (Regan).

Cynoglossus purpureomaculatus Regan, Ann. Mag. Nat. Hist., 1905, p. 26 (Inland Sea of Japan).

Habitat. - Coasts of Southern Japan.

Head, $5 \frac{3}{4}$ in length; depth, $4 \frac{1}{4}$. Eye, 8 in head. Dorsal, 128; anal, 104; scales, 120.

Snout a little more than one-third length of head; interorbital width one-half of diameter of eye. Two nostrils on left side; one between anterior parts of eyes, the other in front of lower eye. Maxillary extending to below middle of eye; rostral hook extending a little beyond mandibulary symphysis. Three lateral lines; the two upper separated by 18 scales.

Color brownish with numerous irregular purplish spots. Total length $215 \mathrm{~mm}$. (Regan.) Inland Sea of Japan.

This species has much smaller scales than $A$. interruptus or $A$. joyneri. We have seen no specimens.

(purpureus, purple; maculatus, spotted).

\section{ARELISCUS SEMILÆVIS (Günther).}

Cynoglossus semilævis Günther, Ann. Mag. Nat. Hist., 1873, p. 379 (Chifu).

Habitat.-Chinese shore of Sea of Japan.

Head, 5 in length to base of caudal; depth, $3 \frac{1}{2}$. Dorsal, 123; anal, 95 ; scales, 145 .

Two nostrils, one between the eyes, the other opposite lower margin of lower eye. Eyes extremely small, the upper not in advance of lower; interorbital space much wider than orbit. Length of snout two-fifths of head; angle of mouth below eye; nearer margin of snout than hind margin of opercle.

Color uniform brown; vertical fins with a white edge; 3 distinct round blackish spots on lateral line. Length, 18 inches. (Günther.)

Chifu, China, not seen by us.

(semilævis, half smooth.)

\section{SYMPHURUS Rafinesque.}

Symphurus Rafinesque, Indice d'Ittiologia Siciliana, 1810, p. 52 (nigrescens).

Bibronia Cocco, Alcuni Pesci del mare di Messina, 1844, p. 15 (ligulata; larvai form).

Plagusia Cuvier, Règne Animal, 2d ed., II, 1829, p. 344 (based on Plagusia of Brown); name preoccupied in Crustaceans, Latreille, 1806.

Plagiusa Bonaparte, Catalogo Metodico, 1846, p. 51 (lactea); substitute for Plagusia preoccupied.

Aphoristia KavP, Archiv fur Naturgesch, 1858, p. 106 (ornata).

Glossichthys Gill, Cat. Fish. E. Coast N. A., 1861, p. 51 (plagiusa).

Ammopleurops GÜNTHER, Cat., IV, 1862, p. 490 (lacteus=nigrescens).

? Bascanius Schï̈te, Naturhist. Tydsskr., V, 1867, p. 269 (tædifer; larval form). 
Acedia Jordan, in Jordan and Goss, Review Flounders and Soles, 1889, p. 321 (nebulosus).

Body elongate, more or less lanceolate in outline, with the eyes and color on the left side; eyes small, very close together, with no distinct interorbital ridge between them; mouth small, twisted toward the blind side; teeth little developed, in villiform bands; edge of preopercle covered by the scales; gill openings narrow, the gill membranes adnate to the shoulder girdle above, joined together and free from the isthmus below; pectoral fins wanting (in the adult); vertical fins more or less confluent; scales ctenoid; lateral line wanting. Ventral fin of eyed side only present, free from the anal; head without fringes.

( $\sigma v^{v} v$, together; $\phi v^{\prime} \omega$, to grow; ovं $\rho \alpha$, tail; from the united vertical fins).

\section{6o. SYMPHURUS ORIENTALIS (Bleeker).}

Aphoristia orientalis Bleek ER, Enum. Poiss. Connus. du Japon, 1879, p. 31, pl. II, fig. 1 (Japan).

Symphurus orientalis JoRDAN and SNYDER, Check-List, 1901, p. 122.

Symphurus sp. Sснмірт, Pisc. Mar. Orient, 1904, p. 249 (Vladivostok).

? Achirus plagusia Basilewsky, Soc. Nat. Mose., 1855, p. 245 (Tehili; Pekin): not Pleuronectes plagusia BLOCK and SNYDER, a Jamaican species of Symphurus.

Habitat. - Coasts of Japan, north of Vladivostok.

Head, 5 in length to caudal base; depth, $3 \frac{1}{2}$. Eye, $10 \frac{1}{2}$ in head; maxillary, $3 \frac{2}{3}$. Dorsal, 100 ; anal, 86 ; scales, 90 .

Mouth curved but scarcely hooked at tip of upper jaw; snout projecting a little beyond mouth. Eyes small, the upper slightly in advance of lower; interorbital space about half vertical diameter of eye. Anterior nostril in a tube near front of upper jaw; posterior nostril in front of upper margin of lower eye. End of maxillary below posterior edge of pupil.

Origin of dorsal above front of upper eye. Ventral not joined to anal.

Color, dusky with 5 diffused dark cross bands, one across opercular region in front of ventral; one across body a little behind front of anal; the other three equally spaced, the last one just anterior to base of caudal. Fine points of dark color scattered profusely over the dorsal, caudal, and anal; the ventral uniform.

Here described from the plate published by Bleeker. The counts of fins and scales are from Bleeker's description and do not agree with the plate.

We have not seen this species, and do not feel sure of the characters ascribed to it. A young specimen of Areliscus interruptus, with the scales lost, may be easily taken for Symphurus.

(orientalis, Eastern.) 


\section{SUMMARY.}

\section{Suborder HETEROSOMATA.}

Family Pleuronectide.

1. Platophrys Swainson, 1839.

1. myriaster (Temminck and Schlegel), 1846; Keerun.

2. Scrops Jordan and Starks, 1904 .

2. grandisquama (Schlegel), 1846; Nagasaki, Owari Bay, Sagami Bay, Wakanoura.

3. kobensis Jordan and Starks, 1906; Kobe.

3. Engyprosopon Günther, 1864.

4. iijimæ Jordan and Starks, 1904; Suruga Bay.

4. Pseudorhombus Bleeker, 1862.

5. cinnamomeus (Schlegel), 1846; Tokyo, Tsuruga, Wakanoura, Kobe, Onomichi, Nagasaki, Hakata, Kawatana, Hongkong.

6. misakius Jordan and Starks, 1906; Misaki, Kobe, Tsuruga, Wakanoura.

7. oligodon (Bleeker), 1857; Formosa.

8. dupliocellatus Regan, 1905.

9. ocellifer Regan, 1905; Hakodate, Yokohama, Tokyo, Kobe, Wakanoura, Mororan, Nagasaki.

10. oligolepis Bléeker, 1869.

\section{Paralichthys Girard, 1858.}

11. olivaceus (Schlegel), 1846; Hakodate, Mororan, Same, Aomori, Matsushima, Tokyo, Yokohama, Misaki, Wakanoura, Kobe, Onomichi, Hiroshima, Kawatana, Nagasaki.

12. coreanicus (Schmidt), 1904.

13. percocephalus (Basilewsky), 1855.

6. Xystrias Jordan and Starks, 1904.

14. grigorjewi (Herzenstein), 1890; Hakodate, Matsushima, Tokyo, Aomori, Uzen.

7. Verasper Jordan and Gilbert, 1899.

15. variegatus (Schlegel), 1846; Tokyo, Yokohama, Matsushima Bay, Onomichi.

16. moseri Jordan and Gilbert, 1898; Iturup, Mororan, Hakodate, Same.

8. Acanthopsetta Schmidt, 1903.

17. nadeshnyi Schmidt, 1903.

9. Cynopsetta Schmidt, 1903.

18. dubia Schmidt, 1903; Uzen.

10. Hippoglossoides Gottsche, 1835.

19. elassodon Jordan and Gilbert, 1880.

20. hamiltoni Jordan and Gilbert, 1899.

11. Cleisthenes Jordan and Starks, 1904.

21. pinetorum Jordan and Starks, 1904; Matsushima Bay. 
12. Protopsetta Schmidt, 1904.

22. herzensteini (Schmidt), 1904; Port Arthur.

13. Hippoglossus Cuvier, 1817.

23. stenolepis Schmidt, 1903.

14. Reinhardtius Gill, 1861.

24. matsuræ Jordan and Snyder, 1901; Sagami Bay.

15. Atheresthes Jordan and Gilbert, 1880.

25. evermanni Jordan and Starks, 1904; Matsushima Bay.

16. Alxops Jordan and Starks, 1904.

26. plinthus Jordan and Starks, 1904; Suruga Bay, Owari Bay.

17. Pleuronichthys Girard, 1854.

27. cornutus (Schlegel), 1846; Hakodate, Aomori, Tsuruga, Tokyo, Yokohama, Misaki, Wakanoura, Kobe, Onomichi, Hiroshima, Nagasaki.

18. Lepidopsetta Gill, 1864.

28. bilineata (Ayres), 1855.

19. Limanda Gottsche, 1835.

$(\S \operatorname{Limanda}$.

29. aspera (Pallas), 1811; Robben Island.

30. proboscidea Gilbert, 1896.

31. iridorum Jordan and Starks, 1906; Mororan, Hakodate, Aomori.

( $\$$ Limandella Jordan and Starks, 1906.)

32. schrencki Schmidt, 1903.

33. angustirostris Kitahara, 1906; Aomori.

34. yokohamæ (Günther), 1880; Mororan, Hakodate, Aomori, Tsuruga, Onomichi, Yokohama, Tokyo, Kobe.

20. Veræqua Jordan and Starks, 1904

35. achne Jordan and Starks, 1904; Matsushima Bay.

21. Dexistes Jordan and Starks, 1904.

36. rikuzenius Jordan and Starks, 1904; Matsushima Bay, Suruga Bay.

22. Araias Jordan and Starks, 1904.

37. ariommus Jordan and Starks, 1904; Matsushima Bay.

23. Pleuronectes Linnaeus, 1758.

38. quadrituberculatus Pallas, 1811; Robben Island.

24. Liopsetta Gill, 1864.

39. obscura (Herzenstein), 1890; Iturup Island.

40. pinnifasciata (Kner), 1870.

25. Platichthys Girard, 1854.

41. stellatus (Pallas), 1811; Mororan, Same, Tokyo, Hakodate, Matsushima, Robben Island. 
26. Kareius Jordan and Snyder, 1900.

42. bicoloratus (Basilewsky), 1855; Otaru, Hakodate, Same, Mororan, Tokyo, Matsushima Bay.

27. Clidoderma Bleeker, 1862.

43. asperrimum (Schlegel), 1846; Hakodate, Mororan, Matsushima, Tokyo.

28. Microstomus Gottsche, 1835.

44. kitaharæ Jordan and Starks, 1904; Tsuruga, Suruga Bay, Tokyo.

45. stelleri Schmidt, 1904; Hakodate, Mororan, Edomo.

29. Glyptocephalus Gottsche, 1835.

(Species undescribed); Hakodate.

FAMILY SOLEIDE.

30. Amate Jordan and Starks, 1906.

46. japonica (Schlegel), 1846; Misaki, Kobe, Wakanoura, Tokyo, Tsuruga, Nagasaki.

31. Aseraggodes Kaup, 1858.

47. kobensis (Steindachner), 1896; Nagasaki.

32. Liachirus Günther, 1862.

48. nitidus Günther, 1862; Formosa, Suzuki, Yamagawa.

33. Zebrias Jordan and Snyder, 1900.

49. zebrinus (Schlegel), 1846; Hakodate, Onomichi, Hiroshima, Tokyo, Kobe, Nagasaki, Formosa.

50. japonicus (Bleeker), 1869; Wakanoura, Tokyo.

34. Esopia Kaup, 1858.

51. cornuta Kaup, 1858; Nagasaki.

35. Paraplagusia Bleeker, 1870.

52. dipterygia (Rüppell), 1828.

36. Usinosita Jordan and Snyder, 1900.

53. japonica (Schlegel), 1846; Tokyo, Same, Matsushima, Suruga Bay, Nagasaki.

37. Cynoglossus Buchanan-Hamilton, 1822.

54. robustus Günther, 1873; Yokohama, Tokyo, Kobe, Onomichi, Nagasaki.

55. brunneus Regan, 1905.

38. Areliscus Jordan and Snyder, 1900.

56. interruptus (Günther), 1880; Tokyo, Matsushima, Onomichi, Wakanoura, Nagasaki, Hiroshima.

57. joyneri (Günther), 1878; Tokyo.

58. purpureomaculatus (Regan), 1905.

59. semilævis (Günther), 1873.

39. Symphurus Rafinesque, 1810.

60. orientalis (Bleeker), 1879. 


\section{$2 \mathrm{BHL}$ Biodiversity Heritage Library}

Jordan, David Starr and Starks, Edwin Chapin. 1906. "A review of the flounders and soles of Japan." Proceedings of the United States National Museum 31(1484), 161-246. https://doi.org/10.5479/si.00963801.31-1484.161.

View This Item Online: https://www.biodiversitylibrary.org/item/32804

DOI: https://doi.org/10.5479/si.00963801.31-1484.161

Permalink: https://www.biodiversitylibrary.org/partpdf/2083

\section{Holding Institution}

Smithsonian Libraries

\section{Sponsored by}

Smithsonian

\section{Copyright \& Reuse}

Copyright Status: NOT_IN_COPYRIGHT

This document was created from content at the Biodiversity Heritage Library, the world's largest open access digital library for biodiversity literature and archives. Visit BHL at https://www.biodiversitylibrary.org. 